Digitized by the Internet Archive in 2007 with funding from Microsoft Corporation 




\section{BOY LABOUR}

AND APPRENTICESHIP 


\section{SOME PRESS OPINIONS}

Times.-" The problem already felt acutely in London and in large towns has now appeared even in the country town and village, and to those who still doubt its extent or seriousness we commend this most instructive work."

Morning Post.-" An important book on an im. portant subject."

Daily News.-" Mr. Bray's book is as full of counsel as of instruction, and it should be in the hands of every student of one of the most serious of social problems." 


\title{
BOY LABOUR AND
}

APPRENTICESH P

\author{
BY \\ REGINALD A. BRAY L.C.C. \\ AUTHOR OF "THE TOWN CHILD"
}

SECOND IMPRESSION

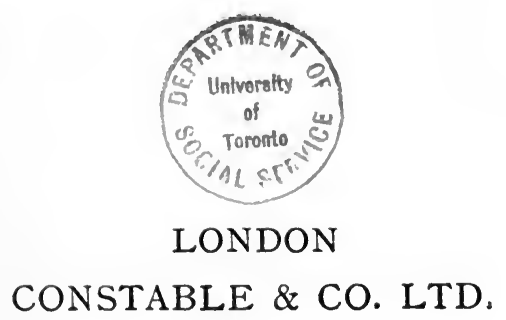

I9I2 


$$
\begin{aligned}
& H D \\
& 4885 \\
& 67 B 7 \\
& 1912 \\
& \frac{663535}{22.8 .57}
\end{aligned}
$$




\title{
CONTENTS
}

Preface

\author{
CHAPTER I
}

The Essentials of Apprenticeship

\section{CHAPTER II}

The Old Apprenticeship -

I. The Age of the Gilds

II. The Statute of Apprentices

PAGE

III. The Industrial Revolution

CHAPTER III

The Age of Reconstruction

\section{CHAPTER IV}

The Guardianship of the State

I. State Supervision -

$\S$ I. State Regulation -

(a) Prohibition of Employment

(b) Limitation of Hours

(c) Protection of Health

$\S$ 2. State Enterprise -

$-\quad 36$

- $\quad 36$

- $\quad 37$

- $\quad 4 \mathrm{I}$

- 43

- $\quad 5^{2}$

- 59 


\section{CHAPTER IV (continued)}

\section{State Training}

(a) The Elementary School -

(b) The Continuation School -

III. State Provision of an Opening -

\section{CHAPTER V}

APPRENTICESHIP OF TO-DAY

I. The Contribution of the State

$\S$ I. State Regulation -

$\S 2$. State Enterprise -

$\S$ 3. Summary

II. The Contribution of Philanthropy

III. The Contribution of the Home -

$\S$ I. The Boy of School Age -

$\S$ 2. The Boy after School Days

IV. The Contribution of the Workshop

PAGE

- 62

63

- 65

$-70$

$\S$ I. London -

(a) The Employment of School-Children I05

(b) The Entry to a Trade - - Ir3

(c) The Passage to Manhood - $\quad \mathrm{I}_{42}$

(d) Summary

- 149

$\S$ 2. Other Towns

(a) The Employment of School-Children ${ }_{5} \mathrm{I}$

(b) The Entry to a Trade

- 155

(c) The Passage to Manhood - - 160

§ 3. Rural Districts - $\quad$ - $\quad$ - $\quad$ - $16 \mathrm{I}$

V. The Break-up of Apprenticeship - - - $\quad$ I65 


\section{CHAPTER VI}

The NeW Apprenticeship

I. Supervision

(a) The Raising of the School Age

(b) The Prohibition of Child Labour

(c) The New Half-Time System

(d) The Parents' Point of View

- I9I

- 192

- 195

- 197

- 202

II. Training -

- 207

III. The Provision of an Opening - - $\quad 221$

IV. General Conclusions

$-23 I$

List of AUthorities

241

INDEX 



\section{BOY LABOUR}

\section{AND APPRENTICESHIP}

\section{CHAPTER I}

THE ESSENTIALS OF APPRENTICESHIP

ORIGINALLY the term " apprenticeship" was employed to signify not merely the practical training in the mysteries of a trade, but also that wider training of character and intelligence on which depends the real efficiency of the craftsman: Apprenticeship was regarded as a preparation for life, and not only as a preparation for the workshop.] It is in this sense that the word is used throughout the present volume.

In a volume concerned with any branch of social reform, and consequently likely to arouse differences of opinion, it is always desirable to start on good terms with the reader. This can best be done by beginning with assumptions the truth of which no one is likely to call in question. In dealing with the problem of boy labour and apprenticeship, it is not difficult to venture on certain statements which will receive the unqualified approval of all. 
An apprenticeship system worthy of the name must satisfy three conditions. I First, it must provide for the adequate supervision of boys until they reach at least the age of eighteen. Before that age a lad is not fit to be his own master, and should remain at least to some extent under the control of elder persons. Such supervision must have respect both to his conduct and to his physical development. 2 Secondly, an apprenticeship system must offer full opportunities of training, both general and special-the training of the citizen and the training of the worker. 3.And, lastly, it must lead forward to some opening in the ranks of adult labour, for which definite preparation has been made, and in which good character may find reasonable prospects of permanent employment. Supervision, training, the provision of a suitable opening - these must be regarded as the three essentials of an apprenticeship system.) How they may be assured is, no doubt, a problem which invites controversy; that they ought to be assured will be allowed by all.

Further, it is perhaps allowable to assume that an apprenticeship system must not be regarded merely as a means of entering a skilled trade. We must not think of it as an organization reserved for a comparatively small section of the community: all must be brought within the sphere of its influence. All boys alike need supervision; all boys alike require some training; all boys alike should see before them, as manhood approaches, the prospects of an opening in some form of sccupation where diligence and aptitude may receive its due reward. 
And all alike must one day play their part in the complex life of the State. We want some to be skilled workers ; we want all to be intelligent and well-conducted citizens. Apprenticeship, then, using the word in its widest sense, must be universal. Here again, it is hoped, the reader may express his agreement.

In what follows an attempt is made to examine the old apprenticeship system, to criticize apprenticeship as it exists to-day, and so to lead on to proposals which will pave the way for the coming of the new and real apprenticeship system of to-morrow. Throughout, the industrial organization will be judged by bringing it to the test of the principles just laid down. An apprenticeship system must be universal; it must make proper provision for three essentials-supervision, training, opening. Where these are wanting, in whole or in part, the youth of the nation must, in a more or less degree, suffer irreparable loss. 


\section{CHAPTER II}

\section{THE OLD APPRENTICESHIP}

PRIOR to the nineteenth century and the beginning of factory legislation the conditions of boy labour were determined in and through the industrial organization of the times. Of this organization, so far as the youthful worker was concerned, the indentured apprenticeship system formed the most characteristic feature. The history of the apprenticeship system falls into three periods. In the first the gilds were the predominant factor; in the second the State, by prescribing a seven years' apprenticeship, insured the continuance of the system; in the third the industrial revolution and the triumph of laissez-faive ushered in the age of decay and dissolution.

\section{I.}

\section{The Age of the Gilds.}

During the Early and Middle Ages the gilds constituted the central feature of the industrial organization. The merchant gilds began to come into existence in the second half of the eleventh century. ${ }^{1}$ They were societies formed for the purpose of obtaining the exclusive privilege of

1 See, for a general description of gilds, "Economic History," by W. J. Ashby ; "Growth of English History and Commerce : Early and Middle Ages," by W. Cunningham. 
carrying on trades. Later they became either identified with the municipal body, or a specialized department of that authority. The craft gilds appeared about a century later, and were associations of artisans engaged in a particular industry. It is not necessary here to enter on a discussion of the complex relations between these two kinds of gilds. The subject is obscure, but, so far as concerns the regulation of boy labour, the general facts are unquestioned.

Either by obtaining a royal charter of their own or by using the authority of the municipality, the gilds were enabled to prescribe, down to the most minute details, the conditions under which the trades of the district were carried on. The control was essentially of a local character, varying from place to place; it was, moreover, a control with, for all practical purposes, the full force of the law at its back. "The towns and even the villages had their gilds, and it is certain that these gilds were the agencies by which the common interests of labour were protected." 1

The gild organization included three classes of personthe apprentice, the journeyman, and the master.

The Apprentice.-The apprentice paid the master a premium, and was indentured to him for a period of years, usually seven. He lived in his master's house, and received from him, in addition to board and clothing, wages on a low and rising scale. The master engaged to teach

1 J. E. Thorold Rogers, "Six Centuries of Work and Wages." p. 566 . 
him his trade, and the boy promised to serve his master honestly and obediently. The following is a typical example of a fifteenth-century indenture $:^{1}$

"This indenture made the xviii of September the year of the reign of King Edward the iiith the xxth between John Gare of Saint Mary Cray in the county of Kent, cordwainer on that oon partie and Walter Byse, son of John Byse sumtyme of Wimelton, in the same county, fuller on that other partie, Witnesseth that the saide Walter hath covenanted with the saide John Gare for the time of vii yeres, and that the saide John Gare shall find the saide Walter mete and drink and clothing during the saide time as to the saide Walter shall be according. Also the saide John Gare shall teche the saide Walter his craft, as he may and can, and also the saide John Gare shall give him the first yere of the said vii yeres iiid in money and the second yere vid and so after the rate of

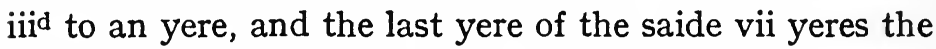
saide John Gare shall give unto the said Walter $\mathrm{x}$ shillings of money. And the saide Walter shall will and truly keep his occupacyon and do such things as the saide John shall bid him do, as unto the saide Walter shall be lawful and lefull, and the saide Walter shall be none ale goer neyther to no rebeld nor sporte during the saide vii yeres without the licence of the saide John. In witness whereof the parties aforesaide chaungeably have put their seales this daye and yere abovesaide."

The Journeyman.-At the expiration of the identure-

1 Quoted, Cunningham, pp. 349-350. 
ship the apprentice became a journeyman. The change of status, beyond bringing with it a rise in wages, made no great difference to the youth. He usually continued to work for his master, and not infrequently remained a lodger in his house. To some extent the master was still responsible for the good conduct of his journeymen. Various regulations forbade the master to entice away the journeymen of others and the journeymen to combine against the masters.

The Master.-By a somewhat similar process of growth and without any sudden break in social status, the journeyman became a master. Between journeyman and master there were no class distinctions. Both worked at their craft; and, in an age preceding the era of capitalistic production on a large scale, the need of capital to start business on his own account presented no difficulties which could not easily be overcome by any intelligent journeyman.

Period of apprenticeship, hours and conditions of work, wages and premiums, were all rigidly determined by the rules of the gild. Through its officers the gild visited the workshops, inspected the articles in process of manufacture, satisfied themselves as to their quality, prescribed methods of production, were empowered to confiscate tools not sanctioned by the regulations, and settled all disputes between the three classes of persons concerned. Masters, journeymen, and apprentices alike benefited by an organization which was created and controlled in their common interests; while the general public were well 
served in the system of expert inspection which guaranteed the quality of the goods supplied. The gild, in short, was " the representation of the interests, not of one class alone, but of the three distinct and somewhat antagonistic elements of modern society-the capitalist entrepreneur, the manual worker, and the consumer at large."1

From the point of view of the boy's training the system presented unique advantages. To the age of twenty-one, and sometimes twenty-four, he was under control. Living in the same house as his master, that control was paternal in character, inspired by a living and individual interest in his welfare. He received a thorough training in the trade to which he was indentured. Finally, when apprenticeship was over, he found ready-made for himself an opening that led upwards from the journeyman to the small master. Under this system there was no boy his own master from an early age, no master irresponsible for the conduct of his boys outside the workshops, and no blind alley of boy employment that closed with boyhood and ended in the sink of unskilled labour.

It its best days the gilds represented something more than a privileged trade organization. The close connection between the gilds and the municipality guarded the interests of the public. "The city authorities looked to the wardens of each craft to keep the men under their charge in order; and thus for every public scandal, or

1 Sidney and Beatrice Webb, "A History of Trade Unionism," p. 17 . 
underhand attempt to cheat, someone was responsible, and the responsibility could, generally speaking, be brought home to the right person." 1 Further, there was no sharp barrier between trade and trade. It is true that no one could enter a trade without being apprenticed, but the person who had served his seven years' apprenticeship in any one trade became free to follow all trades within the city. ${ }^{2}$ The gild system represented therefore something very different from the individualist methods of modern times. There was in a real sense, at any rate in each town, a trade organization under no inconsiderable amount of collective control.

$\rightarrow$ But the organization of the gild was suited only to the conditions of a more or less primitive society. For a country rising rapidly to a front place in the commercial world it was ill adapted. Increasing trade brought wealth and a desire for wealth; and with wealth came power to those who possessed it. The richer members of the gild gained the upper hand in the administration of its affairs and oppressed the poorer. ${ }^{3}$ The gild was no longer an association of equals; and the weaker went to the wall. Competition turned the methods of production in the direction of cheapness rather than good quality; and the supervisory functions of the gild disappeared. In general the whole system, rigid and inelastic, became a heavy drag on the industrial organization. The mem-

1 Cunningham, p. 460.

2 Ibid., p. 345.

3 A. Abiam, "Social England in the Fifteenth Century," p II 8 . 
bers had paid for their privileges in money and a long apprenticeship, and bitterly resented the appearance of intruders not hall-marked by the gild. With shortsighted policy, the gilds limited admissions by exacting high entrance-fees, and strove to secure the maximum of benefits for the smallest possible number.

No longer an association of equals, united by common interests and a common outlook; no longer a guarantee of excellence in matters of craftmanship; no longer the guardian of the interests of the general public, but a narrow sect claiming exclusive privileges-the gilds, rent by strife and envy within, and regarded with open hostility by those outside, drifted slowly towards that inevitable end which awaits those who seek to sacrifice the needs of all on the altar of the selfish desires of the few. "In the sixteenth century," says Dr. Cunningham, "the gilds had in many cases so entirely lost their original character that they had not only ceased to serve useful purposes, but their ill-judged interference drove workmen to leave the towns and establish themselves in villages where the gilds had no jurisdiction." 1 They received their death-blow in the year 1547 , through the legislation directed against the property of the semireligious bodies. With the decay of the gilds and their final dissolution passed the ancient system which had for centuries regulated the conditions of boy labour. So far as the boy was concerned the system was founded on three principles: It recognized his need for prolonged

1 Cunningham. p. 509. 
control and supervision, and made provision for the need by securing for him, through his master, an interest at once individual and paternal. It recognized the need for a thorough training in the mysteries of the craft; and it recognized the need that, at the close of this training, the lad should find opening out for him a career for which he had been specially prepared. And it made provision for these needs by its scheme of inspection and control carried on by those responsible for the common interests of the trade. In short, the gild organization, in its earlier and flourishing days, may justly be regarded as satisfying the conditions of a true apprenticeship system.

\section{II.}

\section{The Statute of Apprentices.}

If the gild system was dead, the principles for which it stood and made provision continued to be as important as ever. Nor under the industrial conditions of the sixteenth and seventeenth centuries did there appear to be any practical difficulty in the way of enforcement. The small master remained, and with him remained the possibility of an effective apprenticeship system. Regulated by custom or by the municipal authority, apprenticeship lost nothing of its old vitality. Indeed, with the increase of trade and the increasing profits derived from trade, it became more popular than ever. None the less, signs are not wanting that people were conscious of faults in the industrial organization. Into the statute book of the period creep 
frequent allusions to intruders who had entered the trade other than through the door of apprenticeship. There was nothing new in these complaints; they existed even in the best days of the gilds. "We seem at a very early time," says Mrs. Green, " to detect behind the gild system a growing class of ' uncovenanted labour,' which the policy of the employers constantly tended to foster, their aim being on the one hand to limit the number of privileged serving-men, and on the other to increase the supply of uncovenanted labour." 1 But with the decay of the supervisory functions of the gild these complaints became more frequent.

The condition of this " uncovenanted labour" has always been the unsolved problem in any apprenticeship system. If uncovenanted labour is allowed to enter a trade on the same terms as those who have served an apprenticeship, the latter have clearly a grievance. They have paid for their privilege in premium and long service at low wages, and not unnaturally demand some assured recompense in return. If, on the other hand, uncovenanted labour is rigidly excluded, there is no method of rapidly increasing the supply of workers in times of expanding trade. From this dilemma there is but one way of escape. All boys, irrespective of the trades they follow, must pass through a system of apprenticeship before they are permitted to earn the wages of a man. Two conditions are necessary to success. First, all boys

1 Mrs. J. R. Green, "Town Life in the Fifteenth Century," vol. ii., p. I02. 
without exception must serve an apprenticeship ; secondly, having served this apprenticeship, they must not in their employment be restricted to the trade to which they have been indentured.

As already shown, the gilds, at any rate in certain districts, allowed a person who had served an apprenticeship in one trade to be free of all the trades of the town. The gilds satisfied the second condition, and in their earlier days, when they included the majority of the population, they satisfied to a large extent the second condition as well. To satisfy the first condition was clearly, as will appear later, the intention of the Statute of Apprentices.

But apart from the problem of uncovenanted labour, the disappearance of the controlling influence of the gilds left many anomalies. Here apprenticeship was regulated by custom, here by charter, and there left undetermined. In one place a certain period of service was exacted, in another place a different period. Finally, in the minds of the leaders of the day there was firmly fixed the belief that, as trade was becoming the life-blood of the nation, there was need of a general and consolidating Act giving the force of law to what was often only a floating custom applicable in a certain district.

In the reign of Elizabeth these growing feelings of discontent found voice in an Act which marks an epoch in industrial legislation. It is usually known as the Statute of Artificers and Apprentices. After reciting the confusion that existed in previous legislation, the preamble continues: 
"So if the substance of as many of the said Laws as are meet to be continued shall be digested and reduced into one sole law and Statute, and in the same an uniform Order prescribed and limited concerning the Wages and other Orders for Apprentices, Servants and Labourers, there is good hope that it will come to pass, that the same law (being duly executed) should banish Idleness, advance Husbandry, and yield unto the hired person, both in the time of Scarcity and in the time of Plenty, a conventient Proportion of Wages." 1

We are here concerned with the Act only so far as it affects the conditions of boy labour. The principal regulations are the following :

"No person shall retain a servant in their services (i.e., in employment for which apprenticeship was required) under one whole Year." 2 Husbandmen may take apprentices " from the age of ro until 2I at least," or till twenty-four by agreement. ${ }^{3}$ Householders in towns may " have and retain the son of any Freeman not occupying Husbandry nor being a Labourer ... to serve and be bound as an Apprentice, after the Custom and Order of the City of London, for seven years at the least so as the Term and years of such Apprentice do not expire or determine after such Apprentice shall be of the Age of twentyfour Years at the least." 4 "None may use any manual occupacyon unless he hath been apprenticed to the same as above." 5 "If a person be required by any Householder

15 Elizabeth, Cap. iv.

${ }^{3}$ Sect. 25.

${ }^{4}$ Sect. 26.

$\checkmark$ Sect. 3I. 
to be an Apprentice and refuse he may be brought before a justice of the peace who is empourred to commit him unto Ward, there to remain until he be contented, and will be bounden to serve as an Apprentice should serve."' 1

The Elizabethan Poor Law gave additional powers with regard to the compulsory apprenticing of those likely to fall into evil ways, and made it lawful for churchwardens and overseers " to bind any such children as aforesaid to be Apprentices, when they shall see conventient, till such Man child shall come to the age of four-and-twenty yeares." 2

Taken together, these two Acts gave to public authorities large powers of control over the growing boy. They did not, indeed, provide that everyone should be apprenticed, but in the majority of occupations no one could be employed unless he had served his time. Nor did they allow a person who had been apprenticed to one trade to work at another. But they applied the system of compulsory apprenticeship to all parts of the country, and they made provision for the proper care, by way of apprenticeship, of neglected children. People of the time were clearly of one mind in their desire to supervise, through the State, the training of the youth. "Contemporary opinion held that it was neither good for society nor trade that the young man should enjoy any independence. 'Until a man grows unto the age of xxiii

15 Elizabeth, Cap. iv., Sect. 35 .

243 Elizabeth, Cap. ii., Sect. 5. Similar powers had been given to Justices of the Peace in earlier Acts (see 27 Henry VIII., Cap. xxv. ; Edw. VI., Cap. iii. 
yeares he for the moste parte, thoughe not alwayes, is wilde, withoute Judgment, and not of sufficient experience to govern himself. Nor (many tymes) grown unto the full or perfect knowledge of the arte or occupation that he professed.' " 1

As to the general effect of the far-reaching Statute of Apprentices, it is not possible to do better than quote Dr. Cunningham : "A proof of the wisdom of the measure seems to lie in the fact that we have no complaints as to these restrictions in the Act or proposals for amending the clauses, but that, on the contrary, there was, on more than one occasion, a demand that it should be rigorously enforced, so that the industrial system of the country should be really reduced to order." 2 For more than two" centuries, without amendment, the Act remained in force ; and while it lasted it provided at least the possibility for the adequate training and supervision of the youth of the country.

These two centuries constitute the second stage in the history of boy labour regulation. From a superficial point of view there appears no essential difference between this period and the preceding. In the first apprenticeship was enforced through the action of the gilds, in the second by special legislative enactment. In either case apprenticeship was, for all practical purposes, compulsory ; but here the similarity ends.

1 W. Cunningham, "Growth of English Industry and Commerce in Modern Times," pp. 29-30.

2 Ibid., p. 33. 
Under the régime of the gilds apprenticeship was enforced, but in addition its conditions were determined by a careful system of regulation. The gild, an association representing the three classes concerned-masters, journeymen, apprentices - supervised the industrial organization in the interests of all alike. In the best days of the gilds the trade, as a whole, inspected the workshops; the trade, as a whole, watched over the training of the youth; the trade, as a whole, so fixed the number of those entering, that at the conclusion of the apprenticeship there was room in the ranks of the skilled artisan for those who had learned their craft.

During the disintegration of the gilds, this second factor gradually disappeared. The Statute of Apprentices did indeed make apprenticeship compulsory, but provided no efficient system of regulation. Measures were frequently advocated and occasionally embodied in Acts for determining the proportion of apprentices to journeymen, but never proved effective. We see gradually emerging the struggle between the conflicting interests of those engaged in production. A seven years' apprenticeship, enforced by law, gave the employers a source of cheap labour, and we begin to hear complaints that the number of apprentices was unduly multiplied and that boys were taking the place of men. To what extent this practice prevailed it is not easy to ascertain ; but there is no question that, at any rate among one class of apprentice-the pauper apprentice-abuses were grave and frequent.

The whole story of the pauper apprentice forms an 
ugly episode in the industrial history of the period. The Statute Book is punctuated with frequent allusion to his unfortunate lot, coupled with proposals for reform, for the most part ineffective. As already mentioned, the overseers had large powers of compulsorily apprenticing the children of the poor. A sum was paid to the employer, the lad handed over, and no steps taken to guard his well-being or guarantee his training. It was inevitable that under conditions such as these abuses should occur. The employer found himself provided with a continual supply of lads, bound to serve him until the age of twenty-one, or sometimes twenty-four; he was not troubled by visits of inspectors; he could use them as he pleased. The luckless apprentices were herded together in overcrowded and insanitary dwellings; they were overworked and underfed; they learned no trade, and were regarded as a cheap form of unskilled labour. If they misbehaved themselves the justices of the peace would punish them; if they ran away the law would see to it that they were returned to their masters; if they complained of ill-treatment there was no one to substantiate the charge. Whole trades seemed to have flourished by exploiting the parish apprentices; and not infrequently the overseer, himself an employer, made a comfortable profit out of their misfortunes. ${ }^{1}$ In his "History of the Poor Law" Sir G. Nicholls summarizes the legislation on the subject. ${ }^{2}$ With the rapid increase

1 See 3 Chas. I., Cap. v.

2 Sir G. Nicholls, "History of the Poor Law," vol. ii., p. 223 et seq. 1898 . 
in the number of paupers at the close of the eighteenth century these evils multiplied, and to an increasing extent engaged the public attention.

If one class of apprentice was thus exploited, it is difficult to resist the conclusion that, in a less degree, others suffered in a similar way. Compulsory apprenticeship, without effective regulation, brought with it the danger of compulsory servitude. The State was conscious of the danger, and duties of supervision were laid on the justices of the peace. The State was likewise conscious of the value of apprenticeship, and gave much attention to the subject. A Commission of Charles I. dealt with the problem, while an Act of James I. was concerned with the misuse of apprenticeship charities, which led to children being brought up in idleness, " to their utter overthrow and the great prejudice of the commonwealth."1 But legislation proved incapable of preventing evils which increased rapidly as the years went by. From the standpoint of the boy the second period, whose characteristic was compulsion without supervision. was distinctly inferior to the first, when the gilds regulated the affairs of the trade for the common good. But if the apprenticeship system was weakening and abuses on the increase, an effective training was always possible. The small master still remained, there was still the call for the all-round craftsman, and the huge changes in methods of production, that were destined to appear later, still lay in the mists of the future.

1 James I., Cap. iii. 


\section{III.}

\section{The Industrial Revolution.}

It was the invention of the steam-engine and the consequent introduction of machinery that ushered in the period of the industrial revolution. In the trades affected the consequences were immediate, profound, and disastrous for boys, journeymen, and small masters alike. " On the whole, machinery rendered it possible in many departments of industry to substitute unskilled for skilled labour." I In branches of certain trades boys took the place of men. "Under the new conditions (of calicoprinting) boys could be employed in what had been hitherto the work of men; so that, in the introduction of machinery, complaints began to be made by the journeymen as to the undue multiplication of apprentices. There was one shop in Lancashire where fifty-five apprentices had been working at one time and only two journeymen; it was obvious that under such circumstances the man who had served his time had very little hope of obtaining employment." 2 A system of compulsory apprenticeship, under such conditions, was exploited for the benefit of the employer, and led inevitably to the injury of the boy. The latter was bound and could not escape, while the former could readily find an excuse for discharging an apprentice. Further, with the growing division of labour and the separation of boys' work

1 Cunningham, p. $6 \mathrm{r}_{5}$.

2 Ibid., pp. 640-64r. 
from men's work, training became less easy. The boy was kept to a single operation, and when his time was up found no further call for his services. The position of the workmen in the trade appeared desperate.) Owing to the competition of boys and the decrease in the demand for his skill, wages were rapidly falling, and at the same time the price of corn was rising by leaps and bounds. The small master, unable to compete with the cheapness of the machine-made goods, fared as badly as the journeyman. Both appealed to Parliament for redress, " usually demanding the prohibition of the new machines, the enforcement of a seven years' apprenticeship, or the maintenance of the old limitation of the number of boys to be taught by each employer." 1

But appeals of this kind fell on deaf ears. The spirit of the age was against interference, and opposition to all form of regulation was rapidly growing. The Statute of Apprentices was disliked by the large employers, and an eager agitation began for its repeal. Though obsolescent, it was still sufficiently alive to be troublesome. A seven years' apprenticeship, it was argued, was unnecessarily long; weaving, for example, could be learnt in two or three years. A Commission was appointed to consider the question, and the large employers pointed out " that the new processes could be learnt in a few months instead of seven years; and that the restriction of the old master craftsman to two or three apprentices apiece was out of

1 Sidney and Beatrice Webb, "History of Trade Unionism," p. 47 . 
the question with the new buyers of labour on a large scale." 1 In the House of Commons "Mr. Sergeant Onslow urged the repeal of the Act, and remarked that ' the reign of Elizabeth was not one in which sound principles of commerce were known.' The true principles of commerce (said another M.P.) appeared at that time to be misunderstood, and the Act in question proved the truth of this assertion. The persons most competent to form regulations with respect to trade were the master manufacturer, whose interest it was to have goods of the best fabric, and no legislative enactment could ever effect so much in producing that result as the merely leaving things to their own courses and operations." 2 The skilled craftsmen, on the other hand, petitioned in favour of compulsory apprenticeship. But in the growing enthusiasm for the theory whose sole tenet lay in the belief that the haven of prosperity lay in the mid-ocean of uncontrolled liberty, all pleas in favour of regulation were treated with contempt. The famous Chalmers, speaking of the Statute of Apprentices, declared that " this law, so far as it requires apprenticeship, ought to be repealed, because its tendency is to abolish and to prevent competition among workmen." 3

In the year I8I4 the Statute of Apprentices was re pealed; ${ }^{4}$ and with its repeal the State washed its hands of all responsibility for the well-being of the youth of the

1 Sidney and Beatrice Webb, "History of Trade Unionism," p. 47.

${ }_{2}^{2}$ Cunningham, p. 66o. ${ }^{3}$ Ibid. $\quad{ }_{54}^{4}$ George III., Cap. xcvi. 
land. Henceforth things were to be left " to their own courses and operations." It is no doubt true that there remained the "Health and Morals of Apprentices Act," passed in 1802 ; this Act prescribed certain conditions as to hours of work and sanitation. But the Act in itself was utterly "ineffective," ${ }^{1}$ and for all practical purposes employers were unfettered in their use or misuse of children.

There remained one more blow to be struck before the condition of the boy touched the lowest level of misery reached in the whole history of this country; and it was soon struck with that relentless vigour which marked the actions of the reformer in those times.

After the repeal of the Statute of Apprentices there was for the lad no sort of legal guarantee of training, no kind of State supervision over his conduct; he could work how and when it pleased him or his parents. But the Poor Law Amendment Act of 1834 made it necessary for him to work how and when it pleased his employer, and took from him all possibility of effective choice. This Act abolished the allowance system in aid of wages. Salutary and even necessary as some reform of the kind was, in the particular way in which it was carried out it fell with crushing force on the unfortunate children. Hitherto parents could receive so much per child out of the rates; from henceforth this was to be illegal. Wages indeed rose, but rose slowly and in patches. The earnings

1 Hutchins and Harrison, "History of Factory Legislation," p. 16. 
of the child were required to make existence even possible for the family. A foreign and impartial student of English affairs has made this truth abundantly clear: " Even granted that the labourer himself now needed no allowance, what had he in place of the allowance for his family and the out-of-work relief? Something in place of these he must have, for even labourers' families must live. ... What was the way out ? The labourer must sell more labour power; and since his own was already sold, he must put that of his family upon the market. This was how the problem of the married man was solved.... We have already seen that the expansion of the gang system took place mainly after I834; it appears that the exploitation of child-labour and women's labour is the main characteristic of the period between the Poor Law and the Education Acts. When Dr. Kay was examined before the Lords' Committee on the Poor Law Amendment Act, he described the astonishment of travellers at the number of women and children working in the fields, and traced their increased employment to the Poor Law. In his own words: "The extent of employment for women and children has most wonderfully increased since the Poor Law came into operation. It has had that effect by rendering it necessary that the children should be so employed in order to adjust the wages to the wants of the family.... And a country clergyman gave expression to similar views in I843: 'By these allowances their children were not then obliged, as now, to work for their subsistence. Their 
time was at their own disposal; and then they were sent more regularly to the schools. But since the new Poor Law this has been reversed." " 1

Those persons who nowadays talk genially of the ease with which the new Poor Law was enforced, would do well to remember that the ease was purchased at the high price of the physical and moral deterioration of the children. Chalmers had got his way, there was now free competition among the workmen ; and free competition among the workmen meant then, as it has always meant since, the unregulated slavery of the weak.

\$ With the repeal of the Statute of Apprentices and the passing of the Poor Law Amendment Act, the old apprenticeship system came to an end. No longer capable of being controlled in the common interests of the trade and the community, no longer capable of being enforced by statutory enactment, the apprenticeship system in its ancient form, though it might linger among certain industries, was destined slowly to disappear. We may regret its disappearance, as the vanishing of a fragment of an old-world life ; but repinings are idle unless directed toward the search for some substitute adequate to the needs of the present.

1 Herr W. Hasbach, "A History of the English Agricultural Labourer," pp. 224, 225. 


\section{CHAPTER III}

\section{THE AGE OF RECONSTRUCTION}

THE last chapter closed on the darkest scene in the long history of child labour in this country. Of the three factors essential to a true apprenticeship, not one was found or its need even recognized in the wild riot of the industrial revolution. Of public or organized supervision of the youth of the land there was not a trace. The controlling influence of the gild system had long since disappeared ; the powers of regulation that lay in the Statute of Apprentices and the Elizabethan Poor Law had been withdrawn; free and unrestricted traffic in the use of children was the watchword of the age. Babies of four and five years worked alongside the adult and for the same number of hours; there were persons of intelligence who saw in this gain extracted from infants not the least of the triumphs of the day. Children's lives were often a mere alternation of two kinds of darkness-the darkness of night giving place to the darkness of the mine. Boys and girls were hired out in troops to a taskmaster, herded in barns regardless of the claims of health and decency, and driven in gangs into the fields of the farmer. Whether in the mine or the factory or on the farm, the present 
profits of the employer, and not the future welfare of the race, were alone considered. Industrial training throughout the new manufacturing districts was treated with open contempt. A person, the masters urged, could learn the trade in a few months; while as for the provision of an opening that would lead from the work of the youth to the work of the adult, it was not to be imagined that a subject of this complexity should receive attention at a time when the narrow circuit of the prosperous factory set a limit to the horizon of men's thoughts. In short, over the whole field of industry the desire for immediate success dominated the larger, but more remote, interests of the future.

What was most significant of the times was not the flood of misery that swept over the country so much as the spirit of complacent satisfaction with which it was regarded. That the industrial revolution was in the cause of progress, the reform of the Poor Law essential, and the decay of the old apprenticeship system inevitable, men of intelligence could not fail to recognize; but they might also have recognized that the profound transformation of the whole social and industrial structure involved could not take place without widespread suffering and demoralization. Men of the day did see these things, but saw them with unconcern. Progress involved change, and change demanded its toll of pain; but it was not the duty of the State to ease the passage or to yield to the outcry of what they looked on as the silly sentimentalist. The general view of contemporary opinion finds itself 
reflected in the Whig and Radical journals. In I8I9. the Edinburgh Review declared: "After all, we must own that it was quite right to throw out the Bill for prohibiting the sweeping of chimneys by boys-because humanity is a modern invention; and there are many chimneys in old houses that cannot possibly be swept in any other manner;" while the Radical paper, the Gorgon, was also inclined to sneer at the House of Commons for " its ostentatious display of humanity in dealing with trivialities like the slave trade, climbing-boys, and the condition of children in factories." 1 The above represents the orthodox opinion of the time. The age was the age of the triumph of the individualist./ His was the gospel that inspired the economist; his were the maxims which guided the legislator; his were the principles that were realized in the practice of the manufacturer. For one brief moment in the history of the world's progress the individualist was supreme; and then the world reeled back in horror from the hell of sin and misery he had created. Even in the early days there were not wanting voices to protest against the theory that in the balance-sheet of the trader was to be found the final test of national righteousness. As far back as the year I80I Mr. Justice Grose, in sentencing an employer for overworking and maltreating an apprentice, declared : "Should the manufacturers insist that without these children they could not advantageously follow their

1 Quoted by Cunningham, " Growth of Industry and Commerce in Modern Times," p. 776. 
trade, and the overseers say that without such opportunity they could not get rid of these children, he should say to the one, that trade must not for the thirst of lucre be followed, but at once, for the sake of society, be abandoned; and to the other, it is a crime to put out these children, who have no friend to see justice done, to incur deformity and promote consumption or other disease. This obviously leads to their destruction-not to their support." 1 And in the year I802 was passed the "Health and Morals of Apprentices Act," an Act important not for its results, which were insignificant, but as a protest against the gospel of individualism, and as the first of the long series of Factory Acts which heralded the dawn of a new age.

This new age, which reaches down to the present time, and of which the end is not yet, was an age of reconstruction. It represented an attempt, unconscious for the most part, to reinstate in a changed form the principles which underlay the old apprenticeship system. It is true that throughout the whole period indentured apprenticeship was in process of gradual decay, and is now become almost a negligible factor in the industıial world ; but it is no less true that from its ruins was slowly rising an organization destined to prove a fitting and even a superior substitute. The final stage of development lies still in the future; the adjustments required to meet the complex needs of modern industry are innumerable ; and

${ }^{1}$ Quoted by B. L. Hutchins and A. Harrison, in " A History of Factory Legislation," p. 15. 
we are only beginning to see the outlines of a new apprenticeship system towards which we have been drifting for nearly a century. To tell in detail the history of these long years of slow progress would be foreign to the purpose of this book; but certain characteristics, which mark the process of change, are sufficiently germane to the discussions of to-day to justify consideration.

In the first place, the forces which repeatedly faced and beat down the resistance of those who stood for unregulated industry were not the forces of economic analysis; few forces that make for great changes are the product of such unimpassioned reason. Factory and kindred legislation were throughout the triumph of sentiment, and not the victory of logic. During the course of the nineteenth century men became slowly more sensitive to the fact of suffering, less tolerant of its continued existence. The Liberal essayist was historically correct when he said contemptuously that humanity was a modern invention. In earlier days little heed was paid to the physical well-being of the individual journeyman or apprentice. If the gilds forbade the carrying on of a craft by night, it was because the dim gloom of ancient illuminants meant bad work, and not because protracted toil made unhealthy workmen. When the State concerned itself with hours of employment, it was to prescribe a minimum, and not to fix a maximum; to keep a man busy, and therefore out of mischief, was deemed more important than to allow him leisure for thought or recreation. 
In this new sentiment of humanity lay the motive power which drove Parliament on to spasmodic acts of factory legislation. The sentiment was at once a source of weakness and a source of strength. It was a source of weakness because sentiment is essentially local in its sphere of influence. It does not search out the objects on which its favours are lavished ; they must be brought by others to its very doors and repeatedly thrust over the threshold till entrance is forced. It lacks the breadth, the insight, and the calm of that imaginative reason which is now slowly taking its place. In the case of suffering, for example, it troubles itself not at all about the more remote causes of suffering or the more remote sufferer, but surges round some particular sufferer or some particular grievance, existing here and now. ${ }^{1}$ Sentiment,

1 In the Report of the Poor Law Commission we have an interesting example side by side of the two forces that make for reform. The Majority Report is altogether the work of sentiment. The proposed variation in the terminology applicable to those in receipt of relief, the loosening of the deterrent system, the advocacy of the more generous treatment of the young and the sick, the general neglect to consider remote causes, and the total absence of any consistent principle, can be explained in no other way. Its cold reception by the British Constitutional Association-that body of people who still hold aloft the tattered banners of the individualist-is but another proof that sentiment, and not the a priori assumptions of the old school, is the guiding spirit. In the Minority Report we see everywhere the mark of the imaginative reason-that reason which, starting with facts and not with theories, strives to picture the long chain of cause and effect which leads up to the sufferer, and finally, seeing the whole process in its true proportions, strikes at the evil where it begins and can be prevented, and not where it ends, when only a more or less modified failure can be looked for. 
at any rate the British type of sentiment, is not touched by abstractions; visions of humanity in the throes of travail leave it unmoved; appeals to the ultimate principles of justice fail to produce even a throb of sympathetic interest; it is only the concrete-the oppressed child or the widowed mother-that lets loose the flood. For the more profound solution of social problems such sentiment is useless, but for the attack of specific evils, especially where the opposition is well organized, it displays amazing stubbornness and resource. Its strength lies in its unreason; argument is of no avail ; here are certain cases of suffering it will not tolerate; a remedy must be found and Parliament must find it ; there will be no peace until something is done.

It was in this way that regulation of child labour began, and indeed has continued down to the present time. The result is patchy, and the removal of evils partial and unsystematic. There has been, for example, no serious attempt made to set up a minimum standard of conditions under which alone children shall be employed ; least of all has the State endeavoured to formulate a new apprenticeship system, adapted to the needs of modern industry. Much indeed has been done in both directions; but much more remains for the future to carry through before we can hope to read in the efficiency of the race the sign-mark of our success. The first characteristic, then, of the age of reconstruction is to be found in the predominating influence of sentiment.

The second characteristic is seen in the triumph of the 
idealist over the combined forces of the doctrinaire and the practical man. Every proposal for regulating child labour was fought on the same lines; there were the same arguments and the same replies. The individualist urged that State interference was in itself an evil, that, though the consequences might be delayed and the immediate effect even beneficial, you might rest assured that in the long-run your sin would find you out. The wealthy citizen declared that if boys might not climb his chimneys, his chimneys must go unswept; the manufacturer predicted certain ruin to his trade if he were forbidden to use children as seemed best to him; while all united in urging that if the children were not at work they would be doing something worse, and pointed out the obvious cruelty of depriving half-starved parents of the scanty earnings of their half-starved offspring.

To all these and similar objections the idealist, with his clearer vision of the reality of things, and firm in his faith that the prosperity of a people could never be the final outcome of allowing an obvious wrong, made response. He sympathized with the individualist for the dreary pessimism of a creed which could see the future alone coloured with hope if heralded by the sobs of suffering children. The wealthy citizen he bade roughly burn his house and build another sooner than sacrifice the lives of boys to the needs of his chimneys. While as for the manufacturer, he told him, as Mr. Justice Grose had told him earlier, that, if his engines needed children as fuel, his was a trade the country was best rid of. To 
those employers who pleaded the small wages of the parents he suggested the grim and crude and obvious remedy of paying those parents more. And the idealist, with the sentiment of the British public to back him, won the day.

But if sentiment gave the idealist his victory, it was the future that brought him a full justification. His sin after many years is yet seeking him; the wealthy citizen found other and innocent means of cleansing his chimneys ; the manufacturer placidly adapted himself to the new conditions, and his trade flourished exceedingly; the wages of parents rose rapidly, and what small measure of health and happiness that has come to the children of the poor during the last century has come to them through the defeat and the defiance of the individualist.

A hundred years have rolled by, and yet to all new regulation the same old objections are raised by the individualist. But his day is gone, and with his day he also is going. A few, indeed, are left, interesting survivals of the early Victorian age. But for the great majority of the population regulation has no fears; they welcome and invite it. And, further, not only are they willing to forbid unsatisfactory conditions of employment, they are also ready to spend public money to secure a proper environment and a suitable training for children. What they will not tolerate is the continued existence of unnecessary suffering; and they are coming more and more to realize that a vast mass of the suffering of to-day is unnecessary. Principles, even though openly pro- 
fessed, will not look suffering in the face and pass on. ${ }^{1}$ Humanity is no longer a modern invention, it has become the guiding spirit of the age.

Thus we can face the morning of the twentieth century in a spirit of hope. We may look for more consistent support and less strenuous opposition than in the past. We may in consequence think out and introduce schemes of a more far-reaching character. Empirical patching will give place to reconstruction on a large scale. In other words, the sentiment of the nineteenth century, wayward and uncertain in its method of action, and at its best troubling itself about a remedy for actual suffering, will be superseded by the imaginative reason of the twentieth, which looks rather to prevention than to cure.

1 A striking instance of this is supplied by the Municipal Reform Party on the London County Council. Opposed in principle to feeding or treating medically children at the cost of the rates, they have yet been compelled to do both these things. And they have been compelled to take action, not by the pressure of public opinion-the public opinion of their own side generally condemned them for forsaking their principles-but by the sheer inability of members to learn, week after week, that hungry children were unfed and sick children left without treatment. 


\section{CHAPTER IV}

THE GUARDIANSHIP OF THE STATE

THE age of reconstruction is not complete, and for the moment we are left with the products of sentiment as revealed in the tangled and piecemeal legislation respecting boy labour. Before making new proposals, it is desirable to survey the existing laws on the subject, in order to discover to what extent the State acts as the guardian of the child by making provision for the three essential factors of a true apprenticeship system-supervision, training, opening. The present chapter will be concerned with a description of the statutory machinery ; in the next the value of the machinery will be tested by examining its results in actual experience.

\section{I.}

\section{State Supervision.}

Supervision is the first essential of an apprenticeship system. A boy must remain under adequate control, as regards his conduct and physical development, until the age of eighteen is reached; before then he is too young to be allowed safely to become his own master. What 
part does the State, as guardian, play in this work of supervision? This volume is concerned with the answer to the question only so far as that answer has a direct bearing on the general problem of boy labour. A statement, for example, of the criminal law, of the law relating to public health, or of the poor law, lies outside its scope.

The guardianship of the State, in respect of supervision, is of two kinds. On the one hand the State appears as the guardian of the boy by restricting his employment, or by forbidding it under certain specified unfavourable conditions-State regulation; on the other hand-as, for example, in its system of education-it assumes a more active rôle, and itself provides for the boy some of the discipline and training he requires-State enterprise.

\section{$\S$ I. STATE REGULATION.}

The State, by regulation, may protect the boy in three ways--

I. Prohibition.-The State may protect the boy by forbidding his employment below a certain age or in certain classes of industry.

2. Limitation of Hours. - The State may protect the boy by fixing a limit to the number of hours during which he may be employed.

3. Health and Safety. - The State may protect the boy by enforcing certain regulations as regards sanitation in the workshop or the proper guarding of machinery, or may 
require a medical certificate to show that the boy is physically fit for the occupation in which he is engaged.

We shall best understand the measure of protection afforded the boy by the State by classifying the statutory regulations under these three headings rather than by taking the individual Acts and analyzing them separately. The principal Acts concerned are the following :

The Factory and Workshop Act, Igor.

Metalliferous Mines Regulation Act, I872.

Coal Mines Regulation Act, I887.

Mines (Prohibition of Child Labour Underground) Act, I900.

The Shop Hours Act, I892.

The Employment of Children Act, I903.

The Prevention of Cruelty to Children Act, I894.

Children Act, I9o8.

And the various Acts relating to compulsory attendance at school-

Elementary Education Act, I876.

Elementary Education Act, I880.

Elementary Education (School Attendance) Act, I893.

And the Act amending this last Act, I899.

To make what follows clearer, and to avoid repetition, it is desirable to add a few remarks about two of these Acts.

The Factory and Workshop Act is concerned with the conditions of employment in premises "wherein labour is exercised by way of trade or for purposes of gain 
in cr incidental to any of the following purposesnamely :

" (i.) The making of an article or part of any article ; or

" (ii.) The altering, repairing, ornamenting, or finishing of any article ; or

“(iii.) The adapting for sale of an article." 1

Premises in which such operations are carried on are divided into these four classes :

I. Textile factories, where mechanical power is used in connection with the manufacture of cotton, wool, hair, silk, flax, hemp, jute, or other like material ;

2. Non-textile factories, where mechanical power is used in connection with the manufacture of articles other than those included in (I), and, in addition, certain industries, such as " print works," or lucifer-match works, whether mechanical power is or is not employed $;^{2}$

3. Workshops where articles are manufactured without the aid of mechanical power ; and-

4. Domestic workshops or factories, where a private house or room is, by reason of the work carried on there,

${ }^{1}$ See Part X. of the Act. Needless to say, the decision as to what kinds of industry come within these definitions has exercised the ingenuity of the lawyer. In one case (Law $v$. Graham), for example, Lord Alverstone, Chief Justice, expressed the opinion that bottling beer is not within paragraph (i.) or paragraph (ii.) above; that by a somewhat strained construction it might be said to be within paragraph (iii.), as being an adapting of an article for sale, but that the powers used in washing the bottles was not " in aid of the process of bottling." Act.

${ }^{2}$ For complete list of such industries, see Sch. VI. of the 
a factory or a workshop, where mechanical power is not used, and in which the only persons employed are members of the same family dwelling there. ${ }^{1}$

The Act also has a limited reference to laundries, docks, buildings in course of construction and repair, and railways. $^{2}$

Certain definitions are important in the interpretation of the regulations. The expression " child" means a person under the age of fourteen, who is not exempt from attendance at school. 3 The expression "young person" means a person who has ceased to be a child, and is under the age of eighteen. ${ }^{4}$ These expressions will be used with this significance in the remainder of this chapter, unless the contrary is stated.

The authority for the enforcement of the Factory and Workshop Act is in general the Home Office, acting through its inspectors. In certain cases, which will be mentioned later, the duty of enforcement is imposed on one or other of the locally elected bodies.

The regulations comprised in the Employment of Children Act are in part of general application, in part dependent on by-laws made by the local authority, and approved by the Home Secretary. The local authority, for the enforcement of the Act and for the making of by-laws, is, in the case of London, exclusive of the City, for which the Common Council is the authority, the London County Council; in the case of a municipal

1 See Part VI. of the Act for details and exceptions.

2 Sects. 103, 104, 105, 106.

${ }^{3}$ Sects. $7 \mathrm{I}$ and ${ }_{5} 6$.

Sect. 156 . 
borough with a population according to the census of I90I of over I0,000, the Borough Council ; in the case of any other urban district with a population of over 20,000, the District Council; in the case of the remainder of England and Wales, the County Council. ${ }^{1}$

These are the chief Acts through which are regulated the conditions of boy labour. Each in a more or less degree is concerned with prohibition, limitation of hours, and health regulations. It now remains to examine the extent of the protection provided.

\section{(a) Prohibition of Employment.}

There is no law forbidding children below a certain age to work for wages. In default of local by-laws, it is still legal to employ children of any age, however young, in a large number of occupations. Prohibition takes the form of forbidding the employment of children in certain trades regarded as specially dangerous to health or demoralizing to character.

I. It is illegal to employ children or young persons " in the part of a factory or workshop in which there is carried on the process of silvering mirrors by the mercurial process or the process of making white lead." 2 And the Secretary of State has power to extend this prohibition to other dangerous trades. ${ }^{3}$

2. It is illegal to employ underground in any mine boys under the age of thirteen, ${ }^{4}$ and no boy under the age of

1 Sect. 13.

${ }^{3}$ Sect. 99 .

${ }^{2}$ Factory and Workshop Act, Sect. 77.

4 Mines Act, I900, Sect. r. 
twelve may be employed above-ground in connection with any mine. ${ }^{1}$

3. A child may not be employed " in the part of a factory or workshop in which there is carried on any grinding in the metal trade, or the dipping of lucifermatches."'2

4. A child under the age of eleven may not be employed in street-trading-i.e., in " the hawking of newspapers, matches, flowers, and other articles, playing, singing, or performing for profit, shoe-blacking, or any like occupation carried on in streets or public places." 3

5. In theatres and shows, children under seven may not be employed at all, and children under eleven can only be employed on a licence granted by a magistrate. ${ }^{4}$

Omitting ways of earning money, as by begging, which cannot properly be regarded as forms of emplyoment, and ancient Acts, such as the Chimney Sweepers Act of I840, which prohibited the apprenticing of children under the age of sixteen to the trade of the sweep, or the Agricultural Gangs Act, I867, which forbade the employment of children under eight in an agricultural gang-Acts which have now little practical importance-the regulations outlined above comprise the whole of the regulations which prohibit throughout the country the employment of boys in certain forms of occupation. For any extension of prohibition we must look to the by-laws

1 Coal Mines Regulation Act, 1887, Sect. 7 .

2 Factory and Workshops Act, Sect. 77.

3 Employment of Children Act, Sects. 3 and 13.

4 Prevention of Cruelty to Children Act, 1894, Sect. 3. 
which may, but need not, be made by local authorities under the provisions of the Employment of Children Act.

Under this Act the local authority may make by-laws prescribing for all children below the age which employment is illegal, and may prohibit absolutely, or may permit, subject to conditions, the employment of children under the age of fourteen in any specified occupation. ${ }^{1}$ The by-laws may likewise prohibit or allow, under conditions, "street trading" by persons under the age of sixteen. ${ }^{2}$ But in either case the by-laws, before becoming operative, must be confirmed, after an inquiry is held, by the Home Secretary. ${ }^{3}$

As an example of prohibition through by-laws made under this Act, the case of London outside the City may be cited. The by-laws of the London County Council forbid the employment of all children under the age of eleven, the employment of children under the age of fourteen as "lather boys" in barbers' shops, and the employment of boys under the age of sixteen in "street trading," unless they wear on the arm a badge provided by the Council.

\section{(b) Limitation of Hours.}

There is no law limiting for all children or for all young persons the number of hours which may be worked. It is still legal in the majority of occupations to employ young persons, and in default of by-laws school-children on days when the schools are closed, for a number of hours

1 Sect. I.

2 Sect. 2.

3 Sect. 4 . 
restricted only by the length of the day. As with prohibition, so the matter stands with the limitation of hours. Glaring evils, just because they glared, have from time to time been dealt with by legislation; other evils no less serious have been ignored merely because they have not chanced to attract attention. The result of this piecemeal legislation and enactment by by-laws is a chaos of intricate regulations, applicable to persons of different age and different sex, varying from trade to trade and from place to place. I am, fortunately, concerned here only with the male sex, and shall begin with the boy young person, and then proceed to the boy child.

The Young Person.-Far the most important, because the most detailed and the most comprehensive, of the Acts dealing with the limitation of hours is the Factory and Workshops Act. Under this Act the hours of employment are restricted by specifying the hours during which alone employment may be carried on. No employment is allowed on Sundays except in the case of Jewish factories closed on Saturday, or of certain industries specially sanctioned for the purpose by the Home Secretary.

In textile factories, ${ }^{1}$ the period of employment for young persons is from 6 a.m. to 6 p.m., or from 7 a.m. to 7 p.m., with two hours for meals, and on Saturdays from 6 a.m. to II.30 a.m., with half an hour for meals. ${ }^{2}$ In non-textile factories and workshops the chief difference lies in the fact that the interval for meals is half an

1 For definitions, see p. 39.

2 Sect. 24. 
hour shorter, while on Saturdays employment is permitted between 6 a.m. and 2 p.m., with half an hour for meals. ${ }^{1}$ In domestic factories and workshops the hours of employment are from 6 a.m. to 9 p.m., with four and a half hours for meals, and on Saturdays from 6 a.m. to 4 p.m., with two and a half hours for meals. ${ }^{2}$

Overtime is in general prohibited. ${ }^{3}$ Employment inside and outside a factory or workshop in the business of the factory or workshop is prohibited, except during the recognized period, on any day on which the young person is employed inside the factory or workshop both before and after the dinner-hour. ${ }^{4}$ Thus the maximum number of hours in a week, including meal-times, during which a young person may be employed is, in textile factories, $65 \frac{1}{2}$; in non-textile factories and workshops, 68 ; in domestic factories and workshops, 85 ; or, excluding meal-times, the hours in the three classes are 55, 60, and 60 respectively.

The Act applies only to those employed in factories and workshops. It has limited application to certain other trades, but the application is unimportant in connection with boy labour. To the regulations quoted there are numerous exceptions, and the Home Secretary has large discretionary powers. ${ }^{5}$

A young person may not be employed " in or about a shop" for a longer period than seventy-four hours, including meal-times, in any one week. Further, an em-

1 Sect. 26.

${ }^{3}$ Sects. 51, 53 .

5 The best detailed account of the Act is found in "The Law Relating to Factories and Workshops," by Abraham and Davies.

2 Sect. III.

4 Sects. 31, 46 . 
ployer may not knowingly employ a young person who has already on the same day been employed in a factory or workshop, if such employment makes the total number of hours worked more than the full time a young person is permitted to work in a factory or workshop. ${ }^{1}$

By-laws may be made limiting the hours of employment of young persons under the age of sixteen engaged in " street trading." 2 The by-laws of the London County Council forbid the employment of such persons " before 7 a.m. or after 9 p.m., or for more than eight hours in any day, when employed under the immediate direction and supervision of an adult person having charge of a street stall or barrow; before 7 a.m. or after 8 p.m. when employed in any other form of street trading."

With the exception of the regulations outlined above, there is no limit to the number of hours during which young persons may legally be employed.

Children.-The most important Acts regulating the hours of employment for children are the Acts which enforce attendance at school. They limit hours, not by fixing a maximum number of hours during which children may be employed, but by pursuing the far more effective plan of seeing that the children are in school, and therefore not in the workshop, during part of the day.

Taken together, these Acts provide that children shall be at school, and consequently not at work, at all times when the schools are opened until the age of twelve is

1 Shop Hours Act, Sect. 3 .

2 Employment of Children Act, Sect. 2. 
reached. There is one exception to this regulation : children may, under a special by-law of the local education authority, be employed in agriculture at the age of eleven, provided that they attend school 250 times a year up to the age of thirteen. This exception is of small importance, as " the number of children who are exempt under this special by-law seems to be very small, not exceeding apparently 400 in the whole country." 1

Between the ages of twelve and fourteen attendance is compulsory, subject to a complex scheme of partial or total exemptions, depending on the by-laws of the local education authority. It rests, for instance, with each local education authority to decide " whether, as regards children between twelve and fourteen, they will grant full-time or half-time exemption, or both, and upon what conditions of attendance or attainments, always subject, of course, to the fact that the by-laws must be approved by the Board of Education, and must not clash with any Act regulating the employment of children." 2 For all practical purposes, it is possible for the local education authority, if they think fit, to insist on such a standard of attainment to be reached before exemption is allowed that, with a few exceptions, relatively insignificant, children are compelled to attend school until the age of fourteen. It is important to remember that these Acts limit the employment of children only during times when the schools are opened. As a general rule, the hours

1 Report of the Consultative Committee on Continuation Schools, vol. i., p. 22.

'Ibid., vol. i., p. 2 I. 
of attendance are between 9 and $\mathrm{r} 2$ in the morning, and between 2 and 4.30 in the afternoon; while the schools are open on five days a week during some forty-four weeks in the year. During holidays, and on Saturdays and Sundays, so far as these Acts are concerned, there is no limit to the numbers of hours a child may work.

A further limit is put on the hours children may work by the Employment of Children Act, I903. A child under fourteen may not be employed between 9 p.m. and 6 a.m. This provision is subject to variation by local by-laws. ${ }^{1}$ Local by-laws may prescribe for children under fourteen : (a) The hours between which employment is illegal; (b) the number of daily and weekly hours beyond which employment is illegal; and $(c)$ may permit, subject to conditions, the employment of children in any specified occupation. $^{2}$

Under this Act the by-laws of the London County Council provide that a child liable to attend school shall not be employed on days when the school is open for more than three and a half hours a day, nor-
(a) Between 8 a.m. and 5 p.m. ;
(b) Before 6.30 a.m. or after 9 p.m. ;

and on days when the school is not open-

(a) Before 6.30 a.m. or after 9 p.m. ;

(b) For more than eight hours in any one day.

On Sundays a child shall not be employed except between the hours of 7 a.m. and I p.m. for a period not

1 Employment of Children Act, Sect. 3 (I).

${ }^{2}$ Sect. I. 
exceeding three hours. A child liable to attend school shall not be employed for more than twenty hours in any week when the school is open on more than two days, or for more than thirty hours in any week when the school is open on two days only or less.

Additional limitations are imposed on the number of hours during which children may be employed by the Factory and Workshop Act. A child between " twelve and thirteen, who has reached the standard for total or partial exemption under the Elementary Education Acts, and consequently may be employed, must still, if employed in a factory or workshop, attend school in accordance with the requirements of the Factory Act. So must a child of thirteen who has not obtained a certificate entitling him to be employed as a young person." I The famous half-time system is not, as sometimes supposed, a special privilege allowed to workshops and factories. It is permissible in all forms of occupation in a practically unrestricted shape. In factories and workshops the conditions are subject to definite regulations. It is, however, only in factories and workshops, and, indeed, only in certain trades among these, that the half-time system has much practical importance. The general regulations, subject, however, to certain variations, are as follows: ${ }^{2}$ Employment must be either in morning and afternoon sets, or on alternate days

1 Abraham and Davies, "The Law Relating to Factories and Workshops," fourth edition, p. $4^{\mathrm{I}}$.

${ }^{2}$ Factory and Workshop Act, 1901, Sect. 25. 
The morning set begins at 6 a.m. or 7 a.m., and ends-

(a) At one o'clock in the afternoon; or

(b) If the dinner-hour begins before one o'clock, at the beginning of dinner-time; or

(c) If the dinner-time does not begin before 2 p.m. at noon.

The afternoon set begins either-

(a) At I p.m.

(b) At any later hour at which the dinner-time terminates; or

(c) If the dinner-hour does not begin before 2 p.m., and the morning set ends at noon, at noonand ends at 6 p.m. or 7 p.m.

On Saturdays the period of employment is the same as for young persons-6 a.m. to II.30 a.m.-but a child shall not be employed on two successive Saturdays, nor on Saturday in any week if on any other days in the same week his period of employment has exceeded five and a half hours.

A child must not be employed in two successive periods of seven days in the morning set, nor in two successive periods of seven days in an afternoon set.

On the alternate day system, the period of employment is the same as for a young person-i.e., from 6 a.m. or 7 a.m. to 6 p.m. or 7 p.m., with two hours for meals ; and on Saturdays from 6 a.m. to II.30 a.m., with half an hour for meals. Under this system a child may not be employed on two successive days, nor on the same day in two successive weeks. 
Under all the systems a child may not be employed continuously for more than four and a half hours without an interval of half an hour for meals. ${ }^{1}$ Nor must a child be employed on any one day on the business of the factory or workshops both inside and outside the factory or workshop. ${ }^{2}$

This system of regulation refers to textile factories, but these include the vast majority of half-timers. The regulations with regard to non-textile factories and workshops are less rigorous; and in the case of domestic workshops and factories there is additional relaxation of the rules.

The parent or guardian of the half-timer is responsible for the child's attendance at school. As an additional precaution against truancy, the employer may not employ the child unless each Monday the child has obtained from the school a certificate of attendance during the past week. ${ }^{3}$

If we take into account the hours worked in the factory and the hours spent in school, we shall find that the half-timer's week of strenuous effort is a long and a weary one. "Taking one week with another, the employment of the half-timer is for twenty-eight and a quarter hours a week in a textile factory, and thirty in a non-textile factory or workshop; and as he is in school zor thirteen or fourteen hours, his total week in school and factory is from forty to forty-four hours." 4
1 Sect. 25.
2 Sects. 3 I and 46.
${ }^{3}$ Sect. 69.

4 Report of the In terdepartmental Committee on the Employment of School-Children, p. I2. 
In view of proposals made later, I have thought desirable to insert in detail the half-time regulations, in order to show how, in the actual carrying out of industrial operations, a half-time system can be put into effect.

(c) Protection of Health.

There is no law prescribing in all cases the conditions as to buildings, sanitary arrangements, and safety, under which alone children and young persons may be employed. There is no law requiring in all cases a medical certificate from children and young persons to show that they are physically suited for the employment in which they are engaged.

It is no doubt true that the buildings in which juveniles are employed come, in respect of sanitation, drainage, and water-supply, under the general Public Health Acts. It is no doubt a fact that local building by-laws occasionally insist on means of escape in case of fire in premises where more than a certain number of persons are employed. It is likewise part of the law of the land that, if a lad in the course of his work meets with a fatal accident, twelve just men and a coroner must sit on the dead body and investigate the cause.

But, apart from such regulations, which are not confined to the employment of juveniles, or, indeed, to employment generally, it is only in special forms of occupation that there are required additional precautions designed to protect the health and safety of the workers. Elaborate rules prescribe the conditions which must be 
observed in the management of a railway or a mine. The Shop Hours Act requires that seats should be provided for shop assistants. Such Acts have in practice only a limited application in the case of children and young persons, who do not to any large extent come into the classes affected.

Here, as in regard to the regulation of hours, the chief Act of importance is the Factory and Workshop Act. This Act makes careful provision, so far as premises are concerned, for the health of the workers, juveniles and adults alike. Whether the provisions are in practice always enforced is a matter open to some doubt.

In the case of factories, ${ }^{1}$ the outside walls, ceilings, passages, and staircases must be painted every seven years, and washed every fourteen months; and in general the premises must be kept clean and free from effluvia, and the floors properly drained. Ventilation must be adequate, and all gases, dust, and other impurities generated in the course of work rendered, so far as is practicable, innocuous to health. In certain cases the inspector may insist on the provision of ventilating fans. Overcrowding is prevented by requiring a minimum space in each room of 250 cubic feet for each person, or during overtime of 400 cubic feet. A reasonable temperature must be maintained in each room in which any person is employed. 'There must be sufficient and suitable supply of sanitary conveniences. In textile factories a limit is set on the

1 The summary of the provisions that follow is founded on "The Law Relating to Factories and Workshops," by Abraham and Davies, chap. ii. 
amount of atmospheric humidity. In certain dangerous or poisonous trades additional precautions are required. The Secretary of State has large powers of imposing additional regulations on the one hand, and of granting exemptions on the other. The authority for enforcing the regulations in factories is the inspector acting through the Home Office.

The regulations applicable to workshops do not differ very materially from those imposed on factories, but the enforcing authority is different. The authority in the case of workshops is the district or the borough council-i.e., the public health authority. The medical officer of health and the inspector of nuisances have for this purpose the power of factory inspectors. A breach of the law on the subject is declared to be a nuisance, and may be dealt with summarily under the Public Health Acts. The district or borough council are compelled to keep a register of the workshops within their area; and the medical officer of health is required to report annually to the council on the administration of the Factory Acts in the workshops and workplaces in the district. A copy of this report must be sent to the Secretary of State, who remains the supreme authority, and in certain cases of default may authorize a factory inspector to take the necessary steps for enforcing these provisions, and recover the expenses from the defaulting council.

An attempt is also made to regulate the sanitary conditions under which out-workers are employed. Where 
provisions are made by the Secretary of State, the employers concerned are made responsible for the condition of the places in which his out-workers carry on work. The employer must keep lists of out-workers. The district council, in cases where the place is injurious to the health of the out-workers, may take steps to have the evil remedied or the employment stopped.

The Act requires machinery to be properly fenced, and special precautions to be taken in cleaning machinery in motion. Children may not clean any part of machinery in motion, or any place under such machinery other than a overhead gearing. Children and young persons may not be allowed to work between the fixed and traversing parts of a self-acting machine while the machine is in motion.

When there occurs in a factory or workshop any accident which either $(a)$ causes loss of life to a person employed in the factory or workshop, or $(b)$ causes to a person employed in the factory or workshop such bodily injury as to prevent him on any one of the three working days after the occurrence of the accident from being employed for five hours on his ordinary work, written notice shall forthwith be sent to the inspector for the district.

In the case of new factories erected since January $I$, I892, and of new workshops erected since January I, I896, in which more than forty persons are employed, a certificate must be obtained from the local authority for building by-laws, stating that reasonable provision for escape has been made in case of fire. With regard to older factories and workshops, the local authority must 
satisfy itself that reasonable means of escape are provided. From these regulations it will be seen that precautions guarding the health of boys are taken in the case of factories and workshops. There are rules, there is an enforcing and inspecting authority, and there is required a report in all cases of serious accident. But, with one exception, no steps are taken to test the adequacy of the precautions by a periodic medical examination of children and young persons, or to prevent the employment of certain individuals who are physically unfit for the work.

The exception is important, and observes attention, because it indicates a possible line of reform. "In a factory a young person under the age of sixteen, or a child, must not be employed ... unless the occupier of the factory has obtained a certificate, in the prescribed form, of the fitness of the young person or child for employment in that factory. When a child becomes a young person, a fresh certificate of fitness must be obtained." 1 A certifying surgeon is appointed for each district. "He must certify that the person named in the certificate is of the age therein specified, and has been personally examined by him, and is not incapacitated by disease or bodily infirmity for working daily for the time allowed by law in the factory." 2 "The certificate may be qualified by conditions as to the work on which a child or young person is fit to "be employed," and the employer must observe such ;conditions. ${ }^{3}$ The surgeon

1 Factory and Workshop Act, Sect. 63, (I) and (2).

${ }^{2}$ Sect. 64 (4).

${ }^{3}$ Sect. 64 (5). 
has power to examine any process in which the child or young person is employed. ${ }^{1}$ A factory inspector who is of opinion that any young person or child is unsuited on the ground of health for the employment on which he is engaged may order his dismissal, unless the certifying surgeon, after examination, shall again certify him as fit. ${ }^{2}$

This provision only applies to young persons under the age of sixteen, and to children. It does not, moreover, apply to workshops. In the case of workshops, the employer may obtain, if he thinks fit, a certificate from the certifying surgeon. ${ }^{3}$ The Secretary of State has, however, power to extend the regulation to certain classes of workshops, if he considers the extension desirable. ${ }^{4}$

In these cases, and these cases alone, is it necessary to call in the doctor to certify the physical fitness of the boy for the employment in which he is engaged. But under the Employment of Children Act, I903, taken in conjunction with the Education (Administrative Provisions) Act, I907, it is possible to extend considerably the system of medical tests. Under the first of these Acts, which applies to children under the age of fourteen"Sect. 3 (4). A child shall not be employed to lift, carry, or move anything so heavy as to be likely to cause injury to the child.

" (5) A child shall not be employed in any occupation likely to be injurious to his life, limb, health, or education, regard being had to his physical condition.
1 Sect. 64 (6).
${ }^{2}$ Sect. 67.
${ }^{3}$ Sect. 65 .
4 Sect. 66. 
" (6) If the local authority send a certificate to the employer saying that certain employment will injure the child, the certificate shall be admissible as evidence in any subsequent proceedings against the employer in respect of the employment of the child."

If the child has left school-and under certain conditions a child can leave school at the age of twelve-it is not easy to see how the local authority can enforce these provisions. But with children attending school, whole or part time, circumstances are different. Medical inspection of school-children is now compulsory, and it is within the power of the education authority to inspect any such children. ${ }^{1}$ They are therefore at liberty to examine any children known to be at work, and any certificate of " unfitness" sent to an employer would probably be effective.

Further, under the Employment of Children Act, Sects. I and 2, a local authority may make by-laws permitting, subject to conditions, the employment of children under the age of fourteen in any specified occupation; and in the case of "street trading" the age is extended to sixteen. It would be possible therefore, subject to the approval of the Secretary of State, to make by-laws requiring a medical certificate of fitness in certain forms of occupation in which children under the age of fourteen are engaged.

1 Education (Administrative Provisions) Act, 1907, Sect. 13. 


\section{§ 2. STATE ENTERPRISE.}

In the preceding sections the State has played a passive part in the supervision of the boy. It has contented itself with giving orders to others, and with taking some more or less inadequate steps to see that its commands are obeyed, but has directly done nothing itself. We are now to see the State assuming duties of its own, and appearing as the active guardian of the child. Individual or voluntary effort having failed, it has been driven, at first reluctantly, but later with increasing readiness, to fill the gap.

The State has now made itself directly responsible for providing schools for the children of the nation. The schools play an important part in the supervision of character. Attendance at school may be either compulsory or voluntary. The law of compulsory attendance has already been stated. ${ }^{1}$ As a rule children must attend school till they reach the age of twelve, and under local by-laws can in general be retained till they reach the age of fourteen. In certain cases, important from the point of view of discipline, the period of compulsory attendance can be prolonged. Children under fourteen found begging, or wandering without home, or under the care of a criminal or drunken guardian, or in general living in surroundings likely to lead to crime, may be brought before a magistrate and sent to an industrial school. ${ }^{2}$ Here they are boarded and lodged, and may be

1 See pp. 46-48.

${ }^{2}$ Children Act, 1908, Sect. 58. 
kept there up to the age of sixteen, after which time the managers of the school have duties of supervision for a further period of two years, with power of recall if desirable. Children who are truants or are convicted of criminal offences can be treated in the same way.

For the majority of boys State guardianship is confined to the years of compulsory attendance. But a considerable number continue their education in various ways, and so remain under some sort of supervision. Children may remain at the elementary school till the close of the school year in which they attain the age of fifteen. The education authority has power to provide and aid secondary and trade schools, and to make these institutions accessible by means of scholarships; and secondary schools, if in receipt of grants from the Board of Education, must in general reserve a quarter of the places for pupils whose parents cannot afford to pay fees. The education authority has power to provide evening continuation classes for those who desire to avail themselves of the opportunities thus afforded. Those who choose to attend these places of higher education continue in some degree under the supervision of the State.

But the supervision of the State through its schools is not confined to the supervision of conduct. The education authority now exercises important duties in connection with the health of the children in the elementary schools. It is now obligatory on every education authority to inspect medically all children on their ad- 
mission to school, and at such other times as may be prescribed by the Board of Education. ${ }^{1}$ In their original memorandum to education authorities the Board of Education required these inspections-on admission to school, and at the ages of seven and ten. ${ }^{2}$ These regulations have not at present been enforced, but the London County Council has now adopted a scheme which practically embodies them. The local education authority is empowered, with the consent of the Board of Education, to make arrangement for attending to the health of the children. ${ }^{3}$ Medical inspection is compulsory, medical treatment optional. Further, the local education authority may draw on the rates to feed schoolchildren, whether their parents are destitute or not, provided it is satisfied that the children, for lack of food, are unable to profit by the instruction given. ${ }^{4}$

Finally, the local education authority may receive into its day industrial schools children at the request of their parents, who must pay towards the expense such sum as may be fixed by the Secretary of State. ${ }^{5}$

It will be seen that, acting through the local education authorities, the State has now assumed large duties in connection with the supervision of children. To submit to the discipline of the schools the vast majority of the children of the county ; to examine medically all children

1 Education (Administration Provisions) Act, 1907, Sect. I3.

2 Board of Education Circular 576, Sect. 12.

3 Education (Administrative Provisions) Act, 1907, Sect. I3.

${ }^{4}$ Education (Provision of Meals) Act, 1906, Sect. 3.

$\checkmark$ Children Act, Sect. 77. 
in these schools; to feed the necessitous children, and to treat medically the ailing children in the elementary schools ; to remove and provide for until the age of sixteen unfortunate children exposed to an unfavourable environment-these are powers which constitute no small measure of State enterprise.

\section{II.}

\section{State Training.}

Training that shall fit a boy for a trade is of two kinds, general and special. The first must develop those mental qualities of alertness, intelligence, and adaptability required in all forms of occupation; the second must give definite instruction in the principles and practice of some particular industry or branch of industries. For the first provision is made in the elementary school system, with its powers of compelling attendance. For the second we must look to the various types of continuation school. Here, under existing conditions, the State can only offer facilities ; it cannot enforce attendance. ${ }^{1}$

Since the passing of the Education Act, I902 and r903, progress has been marked in both directions. The old "voluntary" schools, whose rolls contained the names of half the scholars in the country, and whose limited funds constituted an impassable barrier to all advance, are now maintained out of the rates; and the gap between non-

1 I am here speaking of England ; in Scotland there are limited powers of enforcing attendance. 
provided and council schools is closing up. The breaking up of the small School Boards and the establishment of larger authorities controlling all forms of education have made for efficiency, while the merging of educational matters in the general municipal work is insuring that practical criticism of his schemes which the educationalist always resents but always requires.

\section{(a) The Elementary School.}

It is obvious that, with the variety of children every school contains and their tender age, no definite trade training can be given in the elementary school. On the other hand, we have advanced far beyond the old educational ideal of providing a common and uniform type of instruction in the common school. Types of school are being multiplied to meet the needs of different kinds of pupils. Provision has long since been supplied for the mentally and physically defective, and serious attempts are now being made to break up and classify that huge group which includes the so-called normal child. In addition to the varying types of elementary school which are in process of being adapted to the differing needs of the locality, and the different classes of child, we have, under the elementary school system, what is known as the " higher elementary school." Originally a school specializing in science and of little value, it is tending to become, under the more recent regulations of the Board of Education, a school where a definite bias, either in the direction of commerce or industry, is given 
to the curriculum. It is true that the number of schools called "higher elementary" shows little signs of increase. $^{1}$ This is due to the rigid and inflexible rules of the Board of Education, which seem expressly designed to kill, and not to encourage, the experiment. But while the name is being dropped, the thing is being preserved and multiplied. London, for example, has recently adopted a scheme for the development of sixty of these types of school, to be called "central schools." The curriculum of each school is determined after taking into account the industrial needs of the neighbourhood in which it is placed. The education given is general in character, but the selection of subjects has special reference to some profession or group of trades. Broadly speaking, there are two general types of school, the commercial and the industrial. The industrial type is already subdivided into the woodwork and the engineering type, and further subdivisions will gradually be formed. In these schools no attempt will be made to teach a trade, but such subjects are included in the curriculum as will be found useful in the trade. In the woodwork type, for example, in addition to a considerable amount of time devoted to practical instruction in woodwork, special attention is given to the kinds of arithmetic and drawing required by the intelligent carpenter. An elaborate scheme for picking out between the ages of eleven and twelve the children suitable for these different kinds of school has been drawn up. A four years'

1 Report of Board of Education, rg08-09, p. I10. 
course of instruction is provided for. In order to induce the poorer parents to allow their children to remain beyond the age of compulsory attendance, the education committee offers bursaries, thereby exercising that negative form of compulsion technically known as a bribe. Other education authorities are establishing schools with similar aims. The experiments are recent, and mark an important and new development. Two advantages are anticipated. First, the variety in the types of school and the careful selection of scholars will promote intelligence by providing that particular kind of educational nutriment best adapted for encouraging the growth of a particular order of mind. Secondly, by guiding the interests of boys in the direction of various occupations, it is hoped that on leaving school these interests will lead the boys to enter those occupations for which to some extent they have been prepared, and in which they are most likely to succeed. The elementary schools, as a body, will thus become a kind of sorting-house for the different trades, and be freed from that charge, to some extent justified, of catering only for the lower ranks of the clerical profession.

\section{(b) The Continuation School.}

It is becoming year by year more generally recognized that a system of education which comes to an end somewhere about the age of fourteen is incomplete and profoundly unsatisfactory. Without attendance at a continuation school of some kind, a boy rapidly loses much 
of the effect of his previous education, and at the same time is deprived of all opportunity of enjoying the advantages of a more specialized training. To meet this need a complex system of continuation school has grown up. It lacks, however, the element of compulsion, except that negative form already alluded to-the bribe of a scholarship. Looking at the machinery as a whole, it may be admitted that the State does afford considerable opportunity to those anxious to continue their general education, or to obtain some specific form of technical instruction. Whether sufficient use is made of this opportunity is a question that must be answered in the following chapter. But taking the machinery as a whole, and as it exists under the best education authorities, the machinery does touch to some extent the principal trades and professions. ${ }^{1}$

I. Provision is gradually being made for those likely to succeed in the higher branches of industry and commerce. The number of secondary schools is being increased, their quality improved, and their types varied. Technical institutes providing day and evening classes of an advanced character are being rapidly multiplied. University instruction, aided out of public funds, is becoming more plentiful and efficient, and, whether during the day or in the evening, is year by year offering larger opportunities to students. Progress is especially marked in the faculties of economics and technology. Scholar-

1 For a more detailed account of the machinery considered desirable, see the Report of the London County Council on "The Apprenticeship Question." 


\section{THE GUARDIANSHIP OF THE STATE}

ship systems, more or less incomplete, make access to these institutions possible for the poorer classes of the community. The trend of development seems to suggest that a system of organization, calculated to provide training for the highest positions in the industrial and commercial world, is developing along the following lines:

Between the ages of eleven and twelve the brightest children will be transferred from the elementary to the secondary school. The secondary school will provide a course of instruction extending to the age of eighteen. Broadly speaking, there will be three types of secondary school, the first giving a general and literary education, the second specializing in commerce, and the third in some branch of science and technology. At the age of eighteen the suitable students will be removed to the University, where they will receive a three or four years' course of instruction suitable to the profession they are intending to enter. It is probable that at the age of fourteen there will be an additional, though smaller, transfer of children from the elementary schools, in order that provision may be made for those who have slipped through the meshes of the scholarship net at the first casting. Scholarships with liberal maintenance grants will make readily accessible to all who are fit the advantages of a prolonged education. Evening classes, leading even to a degree, will remain for those who, for one reason or another, have failed to obtain in their earlier years the advanced instruction they now require. 
An organization of this kind is not at present found anywhere in its complete form, but it is sufficiently complete in certain directions to be considered here, where we are concerned with attainments, and not reserved for a later chapter, where we shall be examining new paths of progress.

2. For those likely later to fill the position of foreman, or to become the best kind of artisan, the day trade school is provided. The boys enter the trade school on leaving the elementary school about the age of fourteen or fifteen, and go through a two and sometimes a three years' course of instruction. These schools continue the education of the boy, with special reference to the trade concerned, and at the same time devote a large amount of time to supplying an all-round training in the various skilled operations the trade requires. They are essentially practical in character, and this practical character is often assured by a committee of employers, who visit the school and criticize the methods of instruction.

3. For those already apprenticed to, or engaged in, the trade two forms of instruction are provided. The most satisfactory are the classes attended during the day. Attendance at such times can only be secured by inducing the employers to allow their lads time off during working hours. In some cases the element of compulsion is introduced by the employers, who make attendance at such classes a condition of employment. The other form of instruction is provided during the evening at a technical institute. In either case the instruction is of a practical 
nature, and designed to supplement the training of the workshop.

4. For those who have entered, or desire to enter, the lower walks of commerce, or the civil or municipal service, there is the evening school of a commercial type, usually held in the building of an elementary school.

5. Of the boys who, engaged in unskilled work during the day, are anxious to continue their general education or to improve their position, the evening school again supplies the need. Some practical work is done in the woodwork or metal centres, but the limited equipment of the elementary school stands in the way of any advanced technical instruction. If we omit the commercial classes, already mentioned, attendance at an evening school often means little more than attendance once a week at a class where instruction is given in a single subject, and not infrequently the recreative element is predominant. Recently, and with considerable success, the "course" system has been introduced. Here the students, instead of being present at a single class once a week, attend on several evenings during the week, and go through a course of instruction in several subjects connected together and leading up to some definite goal.

If to these various types of continuation school we add the large number of lectures on numerous subjects, we shall see that the State through its schools supplies a considerable amount of technical instruction. It would be false to say that the boys receive all the training that they need, but it would not be beyond the mark to 
assert that in the case of many education authorities they are afforded all, and not infrequently more than all, the opportunities for which they ask. It is the demand, and not the supply, that is deficient.

\section{III.}

\section{State Provision of an Opening.}

Until the year rgro the provision of openings in suitable occupations was not considered among the duties of the State. It is true that here and there, usually in co-operation with voluntary associations, an education committee made some attempt to place out in trades the boys about to leave school. But any expenditure in this direction was illegal, and under no circumstances was it possible to do anything for those who had already left school. But in the year rgro the State, without premeditation, has found itself committed to the duty of finding openings for children and juveniles. The revolution was upon us before we had seen the signs of its approach.

This assumption of a new duty was the unforeseen result of the establishment of Labour Exchanges. The Act of Igog thought nothing, said nothing, about juveniles. It was passed as a measure intended to deal with the problem of adult unemployment. Now, there is no problem of unemployment in connection with boys and youths; the demand of employers for this kind of labour ap pears insatiable. Nevertheless, no sooner were Labour 
Exchanges opened, than the question of juveniles came to the front. Employers asked for juveniles, and the managers of the local Labour Exchange, eager to meet the wishes of the employer, searched for and found juveniles. Enthusiastic about his work, and prompted by the laudable desire to show large returns of vacancies filled, it did not occur to him that the problem of the juvenile and the problem of the adult had little in common. He was not permitted to remain long in this condition of primitive ignorance. Questions were asked in the House, letters were written to the papers, deputations waited on the President of the Board of Trade, all complaining that the Labour Exchange was becoming an engine for the exploitation of boy labour. In the case of adults, no bargain as to conditions was struck with the employer; the man had to make his own terms. But the boy could not make his own terms, and public opinion had for some years been uneasy about the increasing employment of boys in occupations restricted to boys, and leading to no permanent situation when the years of manhood were reached. Returns showed that it was largely into situations of this character that lads were being thrust by the Labour Exchange. The Board of Trade rapidly realized the evil, and set itself to work to repair the unforeseen mistake. It wisely decided to grapple seriously with the problem, and did not, as it might well have done, restrict the Labour Exchange to adults.

It determined to appoint Advisory Committees to deal 
with juveniles. In London the following machinery is in process of being established : There is a Central Advisory Committee, consisting of six members nominated by the Board of Trade, six by the London County Council, and six by the committee of employers and trade unionists, who advise the Board of Trade on questions of adult employment. The duty of this Central Committee is to advise the Board of Trade as to the appointment of the local Advisory Committees, which will be formed to control the juvenile department in connection with each of the London Labour Exchanges. It will also be the duty of the Central Advisory Committee to advise generally on questions affecting the employment of juveniles. Though the duties of this committee are nominally advisory, its work will in practice become administrative in character. Here then is an organization which in course of time will probably have to deal with the problem of finding suitable occupations for the child and juvenile population of London. Similar bodies are being formed in other towns. As will appear later, this is one of the most important social questions of the day. How these committees will do their work only the future can show. But if the Board of Trade act liberally in matters of expenditure, there is no cause for despondency, and we may well hope that, by the purest of accidents, we are on the threshold of a new era in the history of industrial organization. Chance is not always blind, and some of its wild castings hit the mark. 
Such, in broad outline, have been the achievements of the State during the age of reconstruction, so far as concerns the problem of boy labour and apprenticeship. Guided by sentiment, partial and limited in the sphere of its operations, the State has yet drifted far from the moorings of laissez-faire, and is destined to drift farther as the years go by.

How far the intricate machinery, slowly pieced together during the last three-quarters of a century, is successful when judged by results, what are its more serious defects, and what should be the lines of future advance, before the establishment of a real apprenticeship system, it will be the object of the following chapters to explain. But one truth should now be abundantly clear: of the three essential factors of that system, not one has been altogether neglected by the State, and in certain departments its guardianship has been widely extended. In the department of supervision it has, through its schools, created an organization to watch over and to control the conduct of all its children; it has recently recognized through the same agency its duty to provide for them at least the elements of physical well-being; and through numerous Acts it has endeavoured to insure for the boy worker a minimum standard—low, indeed, but still real—of proper conditions of employment. In the department of training it has covered the land with a network of educational institutions, which offer to all the possibilities of nearly every kind of instruction. While, as regards the provision of an opening, it has realized the urgency of the 
problem, and has taken the first steps to supply the deficiency. These are all, in spite of many shortcomings, solid achievements, hopeful in the present, and more hopeful for the promise they bring of a larger measure of State guardianship in the years that are to come. 


\section{CHAPTER V}

\section{APPRENTICESHIP OF TO-DAY}

A TRUE apprenticeship system, as already explained, must satisfy three conditions: It must guarantee the adequate supervision of the youth of the country as regards physical and moral development until the age of eighteen at least is reached ; it must supply means of effective training, both general and specialized; and, finally, it must provide to those about to cross the threshold of manhood an opening in some form of occupation for which definite preparation has been given. The efficiency of the industrial organization of to-day must be judged by the extent to which these three conditions are satisfied.

To what extent does the apprenticeship of to-day satisfy the conditions of a true apprenticeship system ? To answer this question we must look far beyond the narrow limits of indentured apprenticeship as it still exists. It touches only a fringe, and a vanishing fringe, of the problem. Life for the youth has grown more complex since the passing of the old organization of the gilds; its success or failure is the outcome of the interplay of numerous forces. Four factors contribute, in a more or less degree, to the result. There is the contribution of 
the State-the last chapter was concerned with the description of the machinery which has slowly been set up during the age of reconstruction-we have yet to test its influence in the actual working; there is the contribution of philanthropic enterprise, as represented in the religious bodies, the clubs, the apprenticeship associations, and skilled employment committees ; there is the contribution of the home, with its discipline and training ; and, finally, there is the contribution of the workshop, using this term to include all forms of occupation, with the methods of entry and the organization for securing a supply of labour. Only when we have taken into account the effects of these four factors can we pass judgment on the apprenticeship of to-day.

\section{I.}

The Contribution of the State.

In estimating the contribution of the State towards apprenticeship of to-day, it will be convenient, as in the last chapter, to trace the effect of this influence in two sections, the one devoted to a survey of the results of State regulation, and the other to an examination of the achievements of State enterprise.

\section{$\S$ I. STATE REGULATION.}

In its scheme of regulation the State has aimed, broadly speaking, at securing three results. It has endeavoured to prevent boys from being overworked or wrongly worked; it has sought to guard them from being engaged 
in demoralizing forms of employment ; and it has striven to secure satisfactory conditions within the walls of the workshop.

The third task presents the fewest difficulties. Medical science is sufficiently advanced to prescribe the conditions as to ventilation, heating, sanitation, and cubic contents essential to the health of the boys. The sad catalogue of accidents is sufficiently long to show where danger, through inadequately guarded machinery, is probable. To enforce the necessary regulations is comparatively easy. There must be a suitable number of inspectors, and these inspectors must be specially trained for their work. Neither condition is at present fulfilled. The staff of inspectors is much too small, and the inspectors themselves frequently lack the requisite technical qualifications.

In the work of guarding boys from being engaged in occupations demoralizing to character, the State has only recently taken the first steps. The Employment of Children Act prohibits street trading under certain conditions. As will appear later in this chapter, there are a large number of occupations where regulation is much required. Indeed, it is a comparatively new idea that the nature of the employment of the boy may have a profound influence on the well-being of the man.

In the department of regulation the most elaborate machinery has grown up around the attempts of the State to prevent boys from being overworked or wrongly worked. The difficulties in the way of success have been 
two. There has been the difficulty in getting the necessary law passed. In this respect it is enough to mention that the "half-time" system, in spite of practically universal condemnation, is still permitted, to show the almost insurmountable obstacles presented by vested interests. There is next the difficulty of enforcing the law. It is often urged that it is idle to place on the statute-book laws which can easily be evaded. Too much weight must not, however, be given to this argument. There is a moral effect in the passing of every law. The fact that the State has condemned certain modes of action is an important factor in the formation of public opinion. Many people realize for the first time that the evils which are the result of conduct hitherto regarded as harmless, because not regarded at all, are sufficiently serious to call for State interference. The law may not have its full effect; it will without doubt have some effect.

The question of enforcement is, however, of vital importance, and it is well to consider the limits of the power of enforcement.

The best method of restricting the hours of employment is to see that the boy is somewhere else during part of the working day. The half-time system, which insured that the boy should spend half his time in school, was established, not primarily with a view to his education, but to prevent him from being overworked. It has, moreover, from its point of view, been completely successful, and has in practice been enforced without difficulty. The various laws relating to compulsory attendance at school 
have exercised an influence more potent in the work of limiting the hours of employment than all the other elaborate regulations on the subject. If we see to it that a boy is in school, he cannot at the same time be found in the factory. The machinery for enforcing attendance now runs without difficulty, and its action is uniform and comprehensive.

The next method of restricting employment is the method of prohibition. Here, again, enforcement presents no serious difficulty. If we forbid children under a certain age to work for wages or to take part in certain forms of occupation, it is enough to find them so engaged at any one moment to secure a conviction.

The third method, which seeks to prevent boys from being overworked by setting a limit on the number of hours during which they may be employed, is almost impossible to carry out. The Shop Hours Act is frequently infringed, and only the most rigid system of inspection can get evidence of cases of infringement. Yet even here detection is comparatively easy. A watch can be kept on the number of hours during which a shop is open, and if this exceed the legal limit we have a fair presumption that the shop assistants are over-employed. But in the case of children we cannot draw this conclusion. We are supposing their hours are more limited than in the case of the adults, and the mere fact that the shop is open during a longer period affords no proof that the child is there all the day on all days of the week. To enforce regulations of this kind we must set a watch on the 
individual child, and on a large scale this is impracticable.

In judging of the results of State regulation, as described in the preceding chapter, we may assume that the regulations are enforced-or at any rate are enforceable-where employment is prohibited, or where attendance at school is required, but that regulations which entail the counting of hours have little effect in preventing overwork except by the indirect method of forming public opinion. Further, when we are seeking a path of reform, we must take the road of prohibition or alternative attendance at school.

Leaving general considerations, and coming to details, it may be said that, so far as children under the age of fourteen are concerned, the system of State regulation, though a little cumbersome, covers a considerable part of the field, provided always that local education authorities make full use of the powers conferred by the Education Acts, the School Attendance Acts, the Children Act, and the Employment of Children Act, and provided also that the Board of Education and the Home Office render full and cordial support. Unfortunately, these provisos are very far from being fulfilled. More than 58 per cent. of the population, for example, live in districts where the attendance by-laws allow of conditional exemption at the age of twelve.

It is true that in nearly half the cases a fairly high standard of attainment is required from the children, but with the remainder no higher standard is required than 
that reached by the normal child at the age of twelve. ${ }^{1}$ Or, again, in connection with the Employment of Children Act, out of seventy-four county boroughs, fifty have made by-laws in reference to street trading, but large towns, like Leeds, Nottingham, or Salford, have made none. Out of IgI smaller boroughs and urban districts, only forty-one have made by-laws; and out of the sixty-two administrative counties, other than London and Middlesex, only one. ${ }^{2}$ It may fairly be assumed that, where no by-laws relating to street trading exist, little is done to enforce the other provisions of the Act.

As regards young persons, if we exclude the Acts relating to mines, which affect a comparatively small number of lads, the Shop Hours Act, with its mild provisions of sea.ts for assistants and a maximum week of seventy-four hours, the only Act which can be said to exert a large measure of supervision is the Factory and Workshop Act. Assuming that the system of regulation there found is adequate, and adequately enforced-both assumptions far from being fulfilled in practice-there remain the young persons who do not come within its provisions. The number of these is very large. In the next chapter figures are given relating to the occupations of London children on leaving school and between the ages of fifteen and twenty. A study of these tables will show that not more than at most a third of the young

1 See Report of the Consultative Committee on Continuation Schools, p. 22.

2 Report of the Departmental Committee on the Employment of Children Act, pp. 6, 7 . 
persons are brought within the scope of the Factory and Workshop Act. A large proportion of the lads engaged in the building trades, and practically the whole of those employed in shops, in transport, in commerce, and in general labour, are excluded. In their case there is no State supervision to regulate the conditions of their work.

Coming to concrete examples, the van-boy may in all kinds of weather spend a dozen hours a day lolling on the tail of a cart, idle for much of his time, and for the remainder holding the horses outside a public-house, or lifting weights too heavy for his strength. The errandboy, none too well clad or shod, may, delivering parcels and messages, trudge through the cold and rain over long leagues of streets during long stretches of the week. The office-boy may be cooped up in a dark and ill-ventilated office during most of the hours of daylight. The shopboy may stand ten, twelve, or on Saturdays fifteen hours of the twenty-four in the street or in the shop, with one eye on the goods and the other on a penny novelette. And there is no public authority to say whether the conditions of his employment are satisfactory, no power to have him medically inspected, no possible guarantee to insure that when he passes the threshold of early manhood the vigour and the brightness of youth shall not have given way to the feeble health and the torpor of old age. Unquestionably, we owe much to sentiment for the evils it has denounced and remedied, but we owe also to the régime of sentiment the fact that some two-thirds of 


\section{APPRENTICESHIP OF TO-DAY}

the young persons in the country are engaged in occupations carried on without regulation and unvisited by any inspector of the State.

\section{§ 2. STATE ENTERPRISE.}

The most signal example of State enterprise in the realm of boy labour is to be found in that huge organization of schools, elementary and continuation, which now cover the country, and whose efficiency is rapidly increasing. The organization has already been described; it remains to summarize briefly its principal effects. First, the boys attend school with astonishing regularity. An average percentage of attendances during the year of ninety-five, and even more, is become common. Truancy is rare, and growing rarer. The truant schools are being gradually emptied, and several have been closed. This result is no doubt in part due to the increased fine for non-attendance, and the pressure thus placed on the parent. But excellent attendance implies much more than the elimination of the truant; it means that, after making allowance for absences due to illness and other sufficient causes, the boy attends school with perfect regularity and punctuality at all times when the schools are opened. Now, this ideal is in the case of the vast majority of boys attained. The result must be attributed to the influence of the teachers over the boy. Prosecution of the parent may cure gross irregularity, but perfect attendance can only be secured by enlisting the co-operation of the boy. The first effect of the school, then, is seen in the almost unqualified regularity 
and punctuality of the attendance. If we reflect on the home conditions of many of the boys, we shall be compelled to pay a high tribute of praise to the work of the teacher. The second achievement lies in the admirable order maintained within the walls of the school. Ready obedience is the rule, and not the exception. This is in general not the result of a system of harsh discipline-corporal punishment is decreasing at once in severity and in frequency-it is due to the personal influence of the teacher. In the third place, a spirit of industry and active attention pervades the work of the school. In discussing with the authorities of secondary schools the career of the children who have won scholarships from the elementary schools, I have more than once been told that the chief characteristic of these scholars lies in their patient and strenuous diligence. In this respect they serve as an admirable example to the fee-paying pupils. It is true that the scholars are picked children, but ability and diligence are, as experience shows, by no means inseparable companions. Here, again, we see the effect of the school. Finally, the schools are institutions which make for character in the best sense of the word. The moral training is gradually freeing itself from the "do and don't" of the home, and is beginning to reach the higher level of morality where the command is " to be this, not that." A standard of school honour is being sought for, and sometimes attained. To take a single example. In what is perhaps the poorest school in all London, set in the most squalid and vice-haunted region, it has been made 
a matter of honour with the boys who are receiving school dinners to come to the headmaster as soon as the home circumstances temporarily improve and say: "I don't want a dinner this morning, because father has got a day's work."

Habits of regularity, obedience, and industry, and the cultivation of a sense of honour - these are the chief results of State supervision carried out by means of the schools. Two questions require an answer: Do these qualities, found within the precincts of the school, overflow and affect the conduct of the boys outside the school? Do they last when school-days are over, and the boys gone out to work? With regard to the first, there is good reason to believe that they do overflow. The school training does influence the conduct of the boys outside. No one who has watched a zealous headmaster replace an ancient and inefficient teacher of the old type can fail to have observed a striking change in the behaviour of the boys as seen in the street and in the home. With regard to the second question, we must reply that undoubtedly in many cases the qualities gradually disappear. When we come, as we shall do shortly, to the survey of the conditions of boy labour, we shall not be surprised at this unfortunate truth. It would be difficult to imagine any form of training that would be permanent when all discipline is relaxed or entirely discontinued at the most critical period of the development of the boy.

The elementary school is now made responsible for the supervision of the health of the children. Medical inspec- 
tion of all children is now compulsory, while medical treatment is made legal. The education authority may also draw on the rates to provide meals for necessitous children. It is too soon to estimate the effect of these new powers, but if they are used with wise generosity they should exercise a profound influence on the health of the rising generation.

But however beneficent may be the influence of the elementary school, it comes to an end abruptly at the age of fourteen, and often a year or two earlier. Up to the age of leaving school, the boy is carefully guarded by the State, and then, with no transitional stage, he becomes a man, and, so far as the State is concerned, all control is withdrawn. Two or three per cent., with the help of scholarships, may pass annually to the secondary school, where State supervision is continued. Not more than 30 per cent. of those who leave the elementary school attend an evening school, ${ }^{1}$ and even if they do there is no medical inspection in such places, and little effective discipline is possible for boys attending evening school on two or three nights a week. The remaining two-thirds disappear from the sight of the State, which henceforth renounces all responsibility for their supervision.

We have next to regard the schools as training-grounds for the workmen of the future. We ought not to look to the elementary schools to provide any definite preparation for a trade. Unfortunately, through no fault of

1 "The Organization of Education in London," by R. Blair, Education Officer to the London County Council, p. 29. 
their own, and because of the industrial development of the day, the schools are turning out in thousands lads completely equipped for a certain class of occupation. We have already seen that the most signal triumph of the schools is to be found in the habits of regularity, intelligence, and obedience, which they impress on the boys. Now, these qualities are essential to success in all walks of life; but for one form of employment alone are they all that is required. This form of employment includes those occupations in which boys and boys only are engaged, and where the boys are discharged as soon as they become men. The messenger-boy, the shop-boy, the van-boy, and even the boy who attends to some machine which monotonously performs a single operation - the boy who comes into one of these classes need take with him nothing but the three recommendations of regularity, obedience, and intelligence. We shall trace later the disastrous effects of these forms of employment. It is not without significance that the rapid increase in the number of boys so engaged has synchronized with the rapid improvement in the system of elementary education. It is something of a tragedy that the most signal triumph of the schools should be, perhaps, the cause of their most signal failure.

Definite training must be looked for in the continuation school. It is unnecessary to add much to what has been said in the last chapter; the State offers opportunity, but with its existing powers can do little more. Speaking generally, for the child of comparatively well-to-do 
parents, for the clever child, for the child of unusual energy and physical vigour, these opportunities can be enjoyed; but for the remainder-and that the great majority - they are useless, because beyond the reach of ordinary endeavour.

Of State enterprise in the provision of an opening it is too early to speak; the juvenile branch of the Labour Exchange is only creeping into existence. In the next chapter an attempt will be made to explain how best can be realized the possibilities which lie latent in these institutions.

\section{§ 3. SUMMARY.}

We are now in a position to summarize the achievements and the defects of the contribution of the State towards the creation of a true apprenticeship system. Its machinery of regulation has removed the worst abuses of child labour, and in certain departments of industry protects, with some degree of success, the health of the young persons engaged. Its enterprise in the field of education is providing supervision over the health and conduct of the boy till he reaches the age of fourteen, while for the young person it offers opportunities of longer supervision and technical training.

If much has been done, much more remains undone. Regulation still leaves rampant many of the evils of child labour. Some two-thirds of the boys as they leave school enter occupations where regulation hardly exists. State enterprise for all practical purposes exerts no super- 


\section{APPRENTICESHIP OF TO-DAY}

vision over lads between the ages of fourteen and eighteen -the most important epoch of their lives. Technical training, and even the continuance of general education, are possible only for a favoured few, and for the present there is no State provision of an opening.

These are grave defects, and apprenticeship of to-day stands condemned unless it can be shown that one or other of the remaining factors supply what the State has failed to give.

\section{II.}

The Contribution of Philanthropy.

The second of the general forces, as distinguished from the individual and special influences of the home and the workshop, which may make some contribution towards the apprenticeship of to-day must be sought among the varied religious and philanthropic associations. While we could not expect from these bodies any assistance in the work of technical training, we might hope to find in their midst conditions which make for the better supervision and control of the lads who have left school.

Beginning with the more distinctly religious associations, we find among them practical unanimity of opinion. One and all confess sadly that they are unable to keep in touch with the boys after they have gone out to work. For the tens of thousands of schoolboys who attend Sunday-school there are only hundreds of lads on the roll of Bible-classes. The sudden change from the status 
of schoolboy to the status of wage-earner, which for the majority severed all connection with the education authority, has even more decisively brought to an end the supervision of church and chapel.

The miscellaneous associations represented by clubs, lads' brigades, boy scouts, and the like, have all been called into existence for the express purpose of exerting some measure of control over that transition period of life which separates the boy from the man. How many lads between the ages of fourteen and eighteen come within the sphere of influence it is not possible to say with any exactness. The Twentieth Century League estimated in 1903 that in London about 27,780 boys were connected with institutions of this character, and we shall see later that there are in London about 120,000 boys between the ages of fourteen and eighteen.

It would be no less difficult to weigh the value of the work done. Existing as they do on a voluntary basis, and free from all element of compulsion, such supervision as they exert must take the form of tactful guidance. Their success or failure depends less on the machinery and more on the personal qualities of the manager. The wide and admirable influence of the best clubs is the triumph, not of the system, but of the exceptional individual. Exceptional individuals are, it must be remembered, exceptional, and an organization which depends on their presence is necessarily limited in the extent of its operations. We cannot therefore look to these associations to meet adequately the call for supervision. 
Of recent years numerous associations have been formed with the object of providing suitable openings for boys. There are two sides to their work. On the one hand, situations are found, terms made with employers as to wages and training, and steps taken to see that these terms are carried out. On the other hand, periodic visits are paid to the boy in his home, advice given as to attendance at evening schools, and friendly relations established between boy and visitor. In general, these bodies are concerned with placing out lads in skilled trades, though here and there some attempts have been made to attack the better parts of the unskilled labour market. Work of this character entails the expenditure of much time and money, and requires for the negotiation with employers considerable technical qualifications. Experience has shown that a staff of volunteers cannot alone perform the necessary duties, and paid officers have been appointed. The cost necessarily limits the expansion of the organization. Out of the 30,000 boys who annually leave the elementary schools of London, it is probable that not more than 2 per cent. come under the influence of these associations. On the other hand, if the sphere of their operations is limited, within that sphere it has achieved very considerable success. They have been pioneers in a new movement, have fully justified their existence, and must now look to the State to continue on a larger scale, but on the same general lines, the work that they have begun. Unlike most volunteers, these employment committees welcome this transfer, and are 
now readily placing their services at the disposal of the Board of Trade through its juvenile Labour Exchange.

This brief survey of the contribution of philanthropic enterprise to the apprenticeship of to-day reveals one obvious conclusion: the associations only touch a fringe of the problem, and in no way exert any comprehensive measure of control over the lads between the ages of fourteen and eighteen. Their number, their variety, and their enthusiasm, indicate the urgent need of supervision rather than supervision successfully achieved. We cannot look to them to supplement in any large degree the defects in the scheme of State guardianship, or the more grave defects which will appear when the conditions of home and workshop have been passed in review.

\section{III.}

\section{The Contribution of the Home.}

What contribution does the home make to the solution of the apprenticeship question? We cannot, indeed, expect to find within the walls of the home provision made for the general education of the boy, or the specialized training of the youth ; but it is not unnatural to look to the parent to exercise supervision over his children till manhood is reached, and likewise to offer to the boy leaving school advice and material assistance in the selection of a trade. We are still inclined to regard the family as the one relic of the patriarchal system that has retained a vigorous vitality through all the ages; we are 
still apt to see in the home a small world, edged off from the large world outside, self-centred, self-ruled, and enjoying all the advantages of a benevolent despotism.

To what extent is this general assumption justified by the results of actual experience? The question is of profound importance, and has not received the attention it deserves from those who have written on boy labour. If we can take it for granted that in the normal home we have the means of controlling the boy and the growing lad up till the age of eighteen, we have a solid foundation on which to rest the new apprenticeship. Abnormal homes may need attention; but if the problem of supervision is solved for the majority, if there is an authority to which the boy submits himself as a matter of course, to add training and to organize openings are tasks which should present no serious difficulty.

Can we look to the home to provide this fundamental basis of a true apprenticeship system? To answer this question we must study the homes themselves. A few years ago I devoted a large amount of time to the collection of material touching the character of family life in towns. The results were published in an essayentitled "The Boy and the Family." 1 I may perhaps be allowed to summarize the conclusions there established.

Home varies from home; each may be said to have its own individuality, but each has much in common. To give definiteness to the problem, I endeavoured to

1 "Studies of Boy Life in Our Cities," edited by E. J. Urwick. Dent and Co. 
class the homes under three types. In the main, type number one referred to the inhabitants of one and two room tenements ; type number two embraced the families possessing three rooms; while the third type included those persons fortunate enough to rent more than three rooms. The size of the home proved a rough, though the best attainable, method of classifying the characteristics of the inmates.

Supervision has been interpreted to mean two thingssupervision of health and supervision of conduct.

So far as the supervision of health is concerned, it is probable that very few of the parents belonging to the three types possess the necessary knowledge to carry out this duty. Among all classes of the community ignorance on matters affecting the hygiene of the home is almost universal. But even if knowledge were present, the resources at the disposal of large numbers would prove inadequate to make that knowledge effective. With type number one overcrowding is the rule; with type number two it is common; and only in the third type do we reach conditions of housing favourable to health.

The experience derived from medical inspection of school-children and the administration of the Provision of Meals Act has revealed the deplorable condition of large numbers of children when left to the unaided care of their parents. The returns of necessitous children fed, which are published weekly in the minutes of the London County Council, showed that during the winter of I909-Io. 
at the time of most acute distress, about 9 per cent. of the children in the schools were receiving meals. A careful inquiry, the most elaborate of its kind, made into the home circumstances of the necessitous children in certain schools showed that the number of children actually fed was probably below, and certainly not above, the number who required meals. The same inquiry, with its lurid pictures of squalor and distress, proved how small was the prospect of health for many of those children, even though they were fed at school. It may be regarded as a conclusive demonstration of the call for more searching regulation on the part of the State. ${ }^{1}$ It is probable, however, that the need for food is far larger than that represented by the number of children actually fed. Several inquiries, such as those carried out by Mr. Charles Booth in London, and Mr. Rowntree in York, indicate that the effective income of nearly a third of the population is too small to supply in adequate quantity even the bare necessities of existence.

Medical inspection is now revealing the number of children suffering from definite ailments, and urgently requiring medical treatment, which they have hitherto been unable, in a large proportion of cases, to obtain. It would appear that some ro per cent. suffer from defective vision, about I per cent. from discharging ears, about the same number from ringworm, while at least a

1 "Home Circumstances of Necessitous Children in Twelve Selected Schools." Report of the London County Council. 
third are suffering in health from the result of decaying teeth. ${ }^{1}$

Everywhere we have abundant evidence to show that, from want of supervision, or of the effective means of supervision in the home, large numbers of children are growing up ill-clad, ill-nourished, and suffering from definite diseases, all alike leading to inefficient manhood.

The second department of supervision is concerned with the supervision of character. Can we rest satisfied that the parents exercise over the growing lads that salutary control all growing lads require? The question is of profound importance, if, as all agree, character is the condition of success when the first steps are taken in the industrial world. It is necessary to distinguish between the boy attending school and the boy exempt from compulsory attendance. In what follows I shall draw largely on my essay in "Studies of Boy Life." The conclusions are derived from the experience of many years' residence in a poor part of London, and have been tested by a careful inquiry among ministers of religion, school-teachers, rent-collectors, and others with special knowledge of the subject.

\section{$\S$ I. THE BOY OF SCHOOL AGE.}

If the parents are to control the boys, the boys must come much under the personal influence of the parents;

1 See "Medical Treatment of Children attending Elementary Schools," in Report of the Medical Officer (Education) of the London County Council for the year r9og. See also Report of the Medical Officer of the Board of Education for 1909. 
in other words, rulers and ruled must meet frequently. Now, in all three types of family the father exercises little direct control over the children. If of good character, he is either out at work or out looking for work during five days of the week, and sees the children only in the evening. On Saturday afternoons and on Sundays he is at home; but a week-end visitor cannot be the dominant factor in domestic affairs. If control is exercised, it must be exercised by the mother. To trace her influence, it is necessary to picture the kind of life led by each type. I quote from my essay:

"So far as the first type is considered, it is not easy to say when the children and parents meet. . . . The general order of events is something as follows: If it is one of the days on which he elects to work, the father rises about five o'clock, finds his own breakfast, and then quits the house. Some two or three hours later the school-children get out of bed, wash their faces, take a slice of bread and dripping, and go out. Sometimes the mother rises at that time and gets the breakfast, but in most cases remains in bed. At nine the boys go to school. At noon school is over, and the boys, after amusing themselves in the playground or street for an hour, go home to get some food. The mother meanwhile has risen, dressed the smaller children, performed the irreducible minimum of domestic work, and then left the house to gossip with a neighbour, or earn a few pence by charing. On rare occasions she may cook the children some dinner, but as a rule they get what food they can 
find, and eat it in the streets. Sometimes they receive a halfpenny to buy their own meal at a fried-fish shop. The boys then return to school, escape at half-past four, possibly go home to tea, and then once more turn for amusement to the streets. There they remain until it is dark, and often in summer till dawn begins to break, when at length they seek their dwelling and go to bed. In many cases the boys do not find their way back to their own houses, but take up their quarters for the night in the house of some friend. Sometimes they do not sleep in a house at all. In one case of which $I$ have heard three boys spent a fortnight in a wash-house on the top of some blocks. There they lived an independent existence, getting their food and attending school regularly all the while. Later on, being discovered by a policeman, they were sent to their respective families. . . . Week follows week with little variation to mark the march of time. As brief a fragment of the boy's life as is possible is spent within the common dwelling, which offers him no occupation, and is entirely devoid of interest or attraction. The mother does not demand his presence indoors, while he himself has no wish to be there. The street, and not the house, ought probably to be regarded as the home or meeting-place of the family." 1

Supervision under circumstances of this kind must be an almost negligible factor in the life of the home. Let us now come to the second type. I quote again :

1 "Studies of Boy Life," pp. 22-25 passim. 
"In the second type, as already mentioned, the family usually occupies three rooms. At first sight the conditions found in the former type seem to prevail here also. Indeed, as a matter of fact, the boys spend hardly more time at home than those just considered. Out of school hours they are either in the street or employed in some form of paid work. ... School, street, meals, and bed alternate with one another here in much the same way as they did in the first type. But while the facts remain for the most part unchanged, their setting and colouring are very different. Another atmosphere seems to pervade the whole life; some sense of order and regularity begins to manifest itself; meals are at fixed hours; and the boys are expected home and sent to bed at more or less definite times. They return to their own tenements, and do not spend the night with some of their neighbours. As will appear later, home interests begin to develop; and if the boys spend their leisure in the streets, this is due more to their own choice than to the wish of their parents.... The mother does not display the utter indifference to the state of the dwelling or the habits of the children conspicuous in the first type. Some sort of ideal of home she seems to possess, but to obtain this ideal is beyond her power. She has the look of one who feels that things are wrong, and yet can see no remedy. She notes, for example, the evil influence the street exerts on the characters of her boys, but does not know how to preserve them from its overwhelming attractions." ${ }_{1}$

1 "Studies of Boy Life," pp. 26-28 passim. 
"The chief difference, then, between the first and second type lies not so much in a different kind of life as in a certain change of atmosphere that pervades and transforms the common existence. In the third type this change of atmosphere becomes more conspicuous. A great part of the boy's time is, indeed, still spent outside the dwelling-place, but the life at home begins to assume larger proportions. There is more order and quiet in the house-a condition which reacts favourably on the boys. They are no longer seen hanging about the streets, loafing at the corners, or shouting noisily in the gutters. Though much out of doors, they go farther afield, and visit parks or museums; while, if they stay near home, they will usually be discovered in the school playground. In the evening many of them are indoors, and have various occupations, of which, perhaps, reading is the chief." 1

In type number one, then, there is, for all practical purposes, a complete absence of supervision. In the second type there is a desire for supervision, but the narrowness of the house accommodation thrusts the boys into the streets. In the third type alone are the conditions favourable to supervision.

\section{§ 2. THE BOY AFTER SCHOOL DAYS.}

If the boy while at school is under little parental control, it is not to be expected that this control will be tightened when school days are over. With the first 
type of family there was no supervision before, and there is no more afterwards. The boy is self-supporting, and troubles little about the home, and the home troubles little about him. There is a partial exception in the case of the coster. Here the boy may become one of the regular working members of the establishment, and remains with his father; but the discipline is of a rude and ready sort.

With the second type of family the boy's earnings are of great importance to the family, and the mother does her best to keep him at home. Any exercise of discipline is avoided, lest the lad should take his earnings and go elsewhere. $\mathrm{He}$ is rather in the position of a favoured lodger, whose presence is valuable to the home, and who must be treated well for fear he should give notice.

In the third type of family, the boy, with growing years, passes out of the control of the mother, and is resentful of any restraint exerted by a woman. What supervision he enjoys comes from the father. The two do not meet often; father and son are seldom employed together, and the long distance that frequently separates home and work places the boy beyond the reach of parental control during the greater portion of the week.

Such in broad outline, rendered jagged, no doubt, by numerous exceptions, is the quantity and the quality of the supervision exercised by the town parent over the town boy. Even with the highest type no high standard is reached, while with the lower we cannot contemplate the picture with any degree of satisfaction. Speaking 
generally, the city-bred youth is growing up in a state of unrestrained liberty; and what makes the problem more serious is the fact that all evidence goes to show that this disquieting phenomenon is not an accident, but the direct product of the social and industrial conditions of the times. Towns are growing larger, and with the growth of towns the whole conditions of family life are being transformed. The old patriarchal system is gone; the father is no longer an autocratic ruler in his small world. The family, so to say, has become democratized; we have in it an association of equals in authority. Now, the most ardent advocates of the extension of the suffrage have always limited their demands to an appeal for adult suffrage; they have never clamoured for children to be given a vote. Yet this, for all effective purposes, is what happens in the home in the case of the boy as soon as he has left school. The status of wage-earner has brought with it the status of manhood, and his earnings have conferred on him immunity from control and the right to be consulted in the politics of the home. Another fact, not sufficiently recognized, tends to break down the patriarchal system. With the steady improvement in the State schools, the boy is usually better educated than the father; the father knows this, and the boy knows it too.

It is idle, therefore, to look for any large amount of parental control over the boy who has left school. We must face realities, however unpleasant these realities may happen to be; and one of the realities of the time is 
the independence of the lad. What is equally significant is the suddenness with which this independence comes. Until the age of fourteen he has remained under a carefully designed system of State supervision, exerted by the school authorities; while in a large number of cases the discipline of the home has been an important factor in his existence. At the age of fourteen, as a general rule, the control of school and home end together. The lad goes to bed a boy; he wakes as a man. There should therefore be little cause for surprise if the habits of the school and home are rapidly sloughed off in the new life of irresponsible freedom.

Whether, therefore, we look to the State, to philanthropic enterprise, or to the home, we find no satisfactory guarantee for the supervision of the youth of the country. We have yet to search for this supervision in the workshop; but if it is absent there, we shall be faced with the disquieting phenomenon of the boy at the age of fourteen enjoying the full and complete independence of the adult.

\section{IV.}

The Contribution of the Workshop.

Having examined three out of the four factors which contribute to the apprenticeship of to-day, and found them all inadequate, we must now turn to the workshop in the hope that we shall discover there conditions more favourable to the well-being of the youth of the country. If, however, this last factor prove defective, the appren. 
ticeship of to-day will stand condemned, and the case for drastic reform will become unanswerable. It will therefore be desirable to devote considerable space to this, the central feature of the problem of boy labour.

In what follows it is proposed first to make a detailed study of conditions in London, and then to present a general picture of the state of boy labour in other parts of the country. London has been selected for a detailed study because in a peculiar degree it represents the extreme type of urbanization. There is also the advantage that in the case of London the material required for the examination has to a large extent been collected. The investigations of Mr. Charles Booth, the publications and inquiries on the subject carried out by the London County Council, Mr. Cyril Jackson's report on boy labour presented to the Poor Law Commission, and numerous other writings, have provided for the study of London a mass of information which, though not in all respects exhaustive, is more complete than can be found elsewhere.

\section{$\S$ I. LONDON.}

A study of the problem of boy labour in London involves the study of three questions. First we have to consider the case of the children who, while still attending school, are employed for wages. Next we must devote special attention to the boys as they leave school and distribute themselves among the different occupations. Finally, we must watch the later career of those lads, 
and in particular endeavour to ascertain in what way and with what results is made the difficult passage from the status of the youth to the status of the man.

\section{(a) The Employment of School-Children.}

In London the half-time system is not permitted. The standard of attainment for total exemption has been made sufficiently high to prevent the great majority of boys from leaving school till the age of fourteen is reached. It is, however, a fact that improved methods of instruction and more rapid promotion from class to class are tending to lower the age at which it is possible to obtain a Labour Certificate. How far this opportunity is used it is not easy to say; but in certain schools, situated in the poorer districts, it is alleged that there is a growing tendency for the brighter children to claim exemption in this way. The regularity of attendance is admirable, the average attendance in boys' schools exceeding 90 per cent. We may therefore assume that, if the boys work for wages, they must work at times when the schools are not opened.

To what extent are boys employed while still liable to attend school ? In I899 a return was obtained throughout the elementary schools of England and Wales of the number of children so employed. In London, in the case of boys, the figures were $2 I, 755 .^{1}$ The tables also give the ages of the children, but boys and girls are not

1 Elementary Schools (Children Working for Wages) Parliamentary Return, r899, p. 32. 
separated. If, however, we assume that the number of children of each sex at each age is proportionate to the total number of children of each sex at all ages, we find that 78 per cent. of the boys were eleven and upwards, and 22 per cent. under eleven. The number of boys of eleven and upwards would be about 17,000 . There are in the elementary schools about 70,000 boys eleven years of age and upwards, so that about 24 per cent. of these boys are employed. In other words, nearly a quarter of the boys in the elementary schools above the age of eleven were employed at the time of the return. The actual number of boys who are employed during the course of their school career would be considerably larger, as they would not all be employed at the same moment. The return is more than ten years old, but, with the exception of the children under eleven, it is improbable that there has been much change. Similar figures may be deduced from the Report of the Interdepartmental Committee on the Employment of School-Children, Igor. ${ }^{1}$

With regard to the number of hours worked, Miss Adler's evidence is selected, and typical schools show that $5^{6}$ per cent. were employed for more than twenty hours a week, while I4 per cent. were employed thirtyfive hours or upwards. ${ }^{2}$ In individual cases the figures were much higher. "Thus a boy of eleven years of age, for four shillings a week, was employed for forty-

1 Report on Employment of School-Children, p. 8. Ibid., p. 9. 
three and three-quarter hours in carrying parcels from a chemist's shop, and, except on Sundays, was practically every moment of his life at school or at work from seven in the morning till nine o'clock at night. Another boy, aged thirteen, worked fifty-two hours a week, being employed by a moulding company, and attending a theatre for five evenings a week and for half a day on Wednesday for a matinée - for the last, however, playing truant from school." ${ }^{1}$ The following graphic account taken from a school composition, and obtained under circumstances which guarantee its essential accuracy, shows the amount of work which may be compressed into a single day. It refers to Saturday:

"I first got up from bed about half-past six, and put my clothes on and had a wash. Then I went to work at B.'s, and swept out his shop, and then I did the window out. But after I done the window I had my breakfast and went in the shop again. I started taking out orders that came in. While I was taking the orders out, Mr. B. went to the Borough market for some potatoes, cabbages, and some onions; but when he came home I had to unload his van. After I unloaded his van. he went for some coal, which he sells at one and sixpence a hundredweight, but he got two tons of coal in. Then we had dinner about one o'clock. When we had our dinner, I had a rest till about four o'clock, when I had tea. When I had my tea I had to go and chop some wood, when it was time to shut up the shop. I had my supper and

1 Report on the Employment of School-Children, p. 9. 
went home, and went to bed, and the time was about twelve o'clock." 1 It will be seen that, with the exception of a break in the middle of the day, the boy was on duty for nearly three-quarters of the twenty-four hours, and for part of the time was engaged in heavy manual labour.

What effect does employment have on the physical condition of children under the age of fourteen? "That excessive employment is injurious alike to the education and to the health of the children is hardly in question. It was testified to by witness after witness, many of them in no way likely to be influenced by merely theoretical objections to child labour." 2 On the other hand, most of the witnesses that appeared before the Interdepartmental Committee were of opinion that " moderate work" was in many cases not only not injurious, but positively beneficial." 3 It is not easy to understand what is meant by the last statement. If some form of employment is beneficial, then the 76 per cent. who are not so employed suffer, and steps should be taken to encourage them to work. It is doubtful whether the witnesses would have accepted this conclusion, from which, on their own assumptions, there is really no escape. The difficulty lay in drawing the line. "Most of the witnesses seemed to suggest that twenty hours might be fixed as the maximum weekly limit; but, on the other hand, we found some cases where less than twenty hours a week, if con-

1 Quoted from "Studies of Boy Life," p. 24.

2 Report on Employment of School-Children, p. ro.

3 Ibid., p. II. 
centrated in one or two days, or if done at night, must be injurious." 1

But the evidence of most value on the subject is to be found in a Report of the Medical Officer of the London County Council. ${ }^{2}$ About 400 boys employed outside school hours were examined. The following table, with defects in percentages, was obtained as the result $:^{3}$

\begin{tabular}{|c|c|c|c|c|c|c|}
\hline Hours worked Weekly. & $\begin{array}{l}\text { Actual } \\
\text { Number } \\
\text { of Boys. }\end{array}$ & $\begin{array}{l}\text { Fatigue } \\
\text { Signs. }\end{array}$ & Anæmia. & $\begin{array}{l}\text { Severe } \\
\text { Nerve } \\
\text { Signs. }\end{array}$ & $\begin{array}{l}\text { Deformi- } \\
\text { ties. }\end{array}$ & $\begin{array}{l}\text { Severe } \\
\text { Heart } \\
\text { Signs. }\end{array}$ \\
\hline $\begin{array}{l}\text { All schoolboys of } \\
\text { district workers } \\
\text { and non-workers }\end{array}$ & 3700 & - & 25 & 24 & 8 & 8 \\
\hline Working 20 hours & 3,700 & & 25 & 24 & 0 & 0 \\
\hline or less $\ldots$ & 163 & $5^{\circ}$ & 34 & 28 & I 5 & I I \\
\hline Working 20 to 30 & & & & & & \\
\hline hours $\ldots$ & 86 & $8 I$ & 47 & 44 & $2 I$ & $\mathbf{I}_{5}$ \\
\hline Working over 30 & & & & & & \\
\hline hours $\ldots$.. & 95 & 83 & 45 & $5^{\circ}$ & 22 & 2 I \\
\hline
\end{tabular}

It will be seen that the defects rise rapidly with increase in the hours of work; while, even in the case of those working less than twenty hours, there is a serious deviation from the average. The fact that 50 per cent. of those working less than twenty hours should exhibit signs of fatigue, even where no permanent physical evil results, must seriously affect the value of the school

1 Report on Employment of School-Children, p. II.

2 Report of the Education Committee submitting the Report of the Medical Officer (Education) for the year r9o6. P. S. King and Son.

${ }^{3}$ Report of Medical Officer, p. 22. 
instruction. In every case the workers compare unfavourably with the average for the whole of the workers and non-workers. We cannot view with satisfaction the truth that, even in those employed with moderation, deformities and severe heart signs should be nearly 50 per cent. above the average. The medical officer adds other conclusions no less disquieting. " Working eight hours on Saturday is as inimical as thirty hours during the week, and working through the dinner-hour appears particularly productive of anæmia."1 "Retardation in school work was noted in 209 out of these 330 boys, 86 being one standard, 83 two standards, 37 three standards, and 3 four standards behind that corresponding to their age." 2 As his final conclusion the medical officer states: "We must set up as an ideal the suppression of child labour below twelve years of age, and during school life regulate it to twenty hours weekly, and a maximum of five hours on any one day."'3 The figures, however, would seem to go far in justifying the more drastic remedy of complete prohibition.

It is, however, fair to mention that the Report of the Interdepartmental Committee, and also the Report of the Medical Officer, refer to a state of affairs prior to the passing of the Employment of Children Act. Under this Act, as explained in the last chapter, ${ }^{4}$ employment of children under the age of eleven is forbidden, while the by-laws of the Council place restrictions on the number

1 Report of the Medical Officer (Education) r9o6, p. 23.

2 Ibid., p. $23 . \quad 3$ Ibid., p. $24 . \quad$ See p. 43. 
of hours children may work, and the times of day during which such work may be carried on. It is too soon to judge of the extent to which these restrictions can be enforced. During the first year of effective operation in London there were, in respect of boys under the age of sixteen, I3,46r cases of infringement. Prohibition under a certain age or during certain times of the day is comparatively easy to enforce; but limitation of hours, as experience of the Shop Act shows, is extremely difficult to enforce, and peculiarly difficult where, as with school-children, persons are not employed regularly, but work irregularly at times when the schools are not open. To get evidence sufficient to justify convictions is almost impossible, except in a few outrageous cases.

What, if any, effect does the employment of schoolchildren have on the general question of the preparation for a trade? Into this general question the Interdepartmental Committee did not enter. They did indeed regard certain forms of occupation as injurious, while they pronounced as beneficial employment in moderation. But this statement has apparently reference only to matters of health, and not to the relation of employment during school days to employment afterwards. The question is of great importance, as habits, in respect of work for wages, formed by the boy cling persistently to the youth. It is necessary, therefore, to pay some attention to the characteristics of the work which schoolboys undertake. In London 90 per cent. of the work 
would be included in the three following classes: (I) Shops-errand-running and delivery of parcels, milk newspapers, and watching the goods spread on the counters outside the shops; (2) domestic-knife and boot cleaning, and occasionally baby-minding; and (3) street employment-hawking of newspapers, matches, and flowers, organ-grinding, and the like. Now, none of these forms of occupation provide any trade-training, or offer an opening with satisfactory prospects, to the boy as he leaves school. On the other hand, this class of work has distinctly injurious effects. First, it is employment of a casual character. Affected as it is, on the one hand, by attendance at school, and on the other by Saturdays and holidays, it is essentially irregular as regards hours. Secondly, it is easy to obtain, and consequently lightly undertaken and lightly dropped. Where another situation can be obtained at will, there is no demand on the worker to display the qualities that make for permanence of employment. Thirdly, it is work in which youths as well as boys are engaged; in other words, it does provide an opening to the boy as he leaves school-an opening which he is likely to accept, because it is the most obvious, but at the same time an opening in one of those forms of occupation entrance into which we should, as will appear later, do our utmost to discourage. It is singularly unfortunate that a boy's first association with any kind of paid employment should be of this nature. And, finally, it is at least open to grave doubt whether that sense of independence of home which comes with 
the consciousness of earning wages should begin at as early an age as twelve or thirteen.

It would not be easy to imagine a more unsatisfactory form of preparation for a trade than that provided by the kind of work carried out by wage-earning children. If we add to this demoralizing influence the injurious effect on health and education, the case for total prohibition of boy labour during school-days becomes very strong.

\section{(b) The Entry to a Trade.}

The great majority of boys remain at the elementary school till they attain the age of fourteen; it is no less true that the vast majority cease attendance as soon as that age is reached. The period of the next four yearsthat is, from fourteen to eighteen-forms the most critical time of their career. It is during these four years that the boy must, if ever, have taken the first steps towards learning a trade. During this interval his physical strength must mature, his character take on itself a more or less permanent set, and the question whether his education shall represent something more than a faint shadow of early impressions be finally determined. In short, it is during these four years that the future citizen is made or marred.

The previous survey, whether of the factors which contribute to the apprenticeship of to-day, or of the evils which are found among wage-earning school-children, does not guarantee a favourable start in the world of whole-time employment. Each year about 30,000 boys 
leave school at the age of fourteen to take up some form of work. These figures do not agree with the Census returns, because the latter include all London boys in all classes of society, whether at school or at work. Here we are concerned only with the boys of fourteen who leave the elementary school with the intention of earning their own living. Between the ages of fourteen and eighteen there will therefore be 120,000 boys. It is the careers of these 120,000 boys that we must now try to follow.

What are the first occupations selected by these I20,000 boys? During the last few years the London County Council has endeavoured to find an answer to this question. Each head-master of an elementary school is required annually to fill up a form in respect of each boy who has left the school during the preceding twelve months. The information asked for is "occupation of parent," " occupation of boy," " whether skilled or unskilled," or " whether a place of higher education is attended." Returns have been received and summarized for the years $1906-07$ and r907-08. The first return was incomplete, but the second included the vast majority of those who left. Below is given the summary for the two years :

\begin{tabular}{|c|c|c|c|}
\hline & Skilled. & Unskilled. & $\begin{array}{c}\text { Higher } \\
\text { Education. }\end{array}$ \\
\hline Number & 8,662 & I $_{5,910}$ & 1,524 \\
\hline Percentage & $33 \cdot 2$ & $6 I \cdot 0$ & $5 \cdot 8$ \\
\hline Percentage, I906-07 & $28 \cdot 5$ & $67 \cdot 9$ & $3 \cdot 6$ \\
\hline
\end{tabular}


It will be seen that, including those who went to some higher form of education, little more than a third of the boys left school to enter a skilled trade. ${ }^{1}$

\section{TABLE I.}

\begin{tabular}{|c|c|c|c|c|}
\hline \multirow{2}{*}{ Class of Occupation. } & \multicolumn{2}{|c|}{ Number. } & \multicolumn{2}{|c|}{ Percentage. } \\
\hline & Parent. & Boy. & Parent. & Boy. \\
\hline Trades and industries & $6 I_{5}$ & 347 & $40 \cdot 87$ & I $8 \cdot 74$ \\
\hline Domestic offices or services & 23 & 46 & $\mathrm{I} \cdot 52$ & 2.48 \\
\hline $\begin{array}{l}\text { Transport (including messen- } \\
\text { gers, errand-boys, van- } \\
\text { boys, etc.).. }\end{array}$ & I9I & 829 & $12 \cdot 69$ & $44 \cdot 76$ \\
\hline Shopkeepers, shop-assistants, & & 029 & 1269 & $44 \%$ \\
\hline and dealers.. & I37 & 133 & $9 \cdot$ ro & $7 \cdot 18$ \\
\hline Commercial occupations & 61 & $r_{4} \mathrm{I}$ & $4 \cdot 05$ & $7 \cdot 61$ \\
\hline General labour $\quad \ldots$ & 436 & $2 I_{5}$ & $28 \cdot 98$ & $\mathrm{II} \cdot 6 \mathrm{I}$ \\
\hline Professional occupations and & & & & \\
\hline their subordinate services & II & 5 & 0.73 & 0.27 \\
\hline General or local government & 26 & 6 & $\mathrm{x} \cdot 73$ & $0 \cdot 32$ \\
\hline Defence of the country & 5 & I & $0 \cdot 33$ & 0.06 \\
\hline Higher education $\quad .$. & - & 27 & - & $r \cdot 45$ \\
\hline Unemployed .. $\quad$.. & - & 102 & - & $5 \cdot 5^{2}$ \\
\hline Total & 1,505 & $\mathrm{r}, 85^{2}$ & $100 \cdot 00$ & $100 \cdot 00$ \\
\hline
\end{tabular}

It is unfortunate that no full analysis has been made of these returns. The value of the information which would have thus been obtained was not supposed to justify the labour and expenditure involved in such an analysis. I have, however, roughly analyzed nearly

1 Report on the Apprenticeship Question, Minutes of the Education Committee of the London County Council for February 24, 1909, p. 414. 
4,000 cases, and endeavoured to classify the occupations, in accordance with the table founded on the Census return which will be given later. ${ }^{1}$ I selected for this purpose typical districts in London. Table I. includes returns

TABLE II.

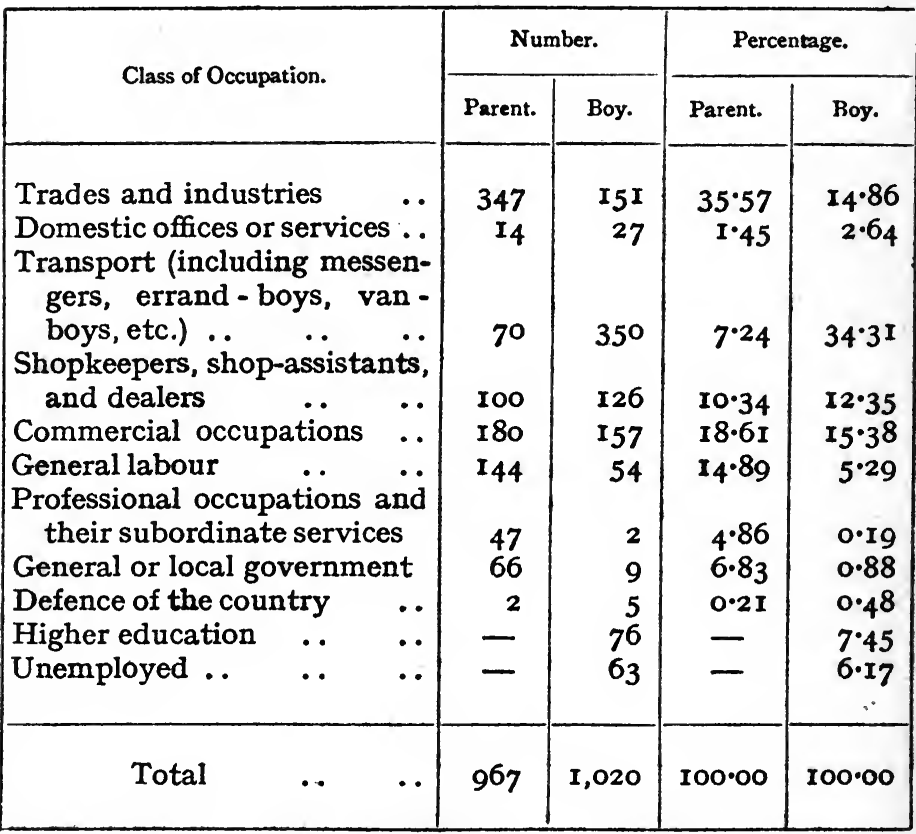

from all the schools in the electoral areas of Bermondsey, North Camberwell, and Walworth ; it represents a typical miscellaneous working-class district. Table II. includes the electoral areas of Dulwich and Lewisham; it may be

1 The substance of what follows appeared in an article published in the Economic Journal for September, 1909, and is reproduced by the kind permission of the Editor. 
regarded as typical of suburban villadom so far as its inhabitants send their children to the elementary schools. Table III. includes the electoral areas of Whitechapel and St. George's-in-the-East, districts distinguished by the presence of a large number of small trades and sweated

TABLE III.

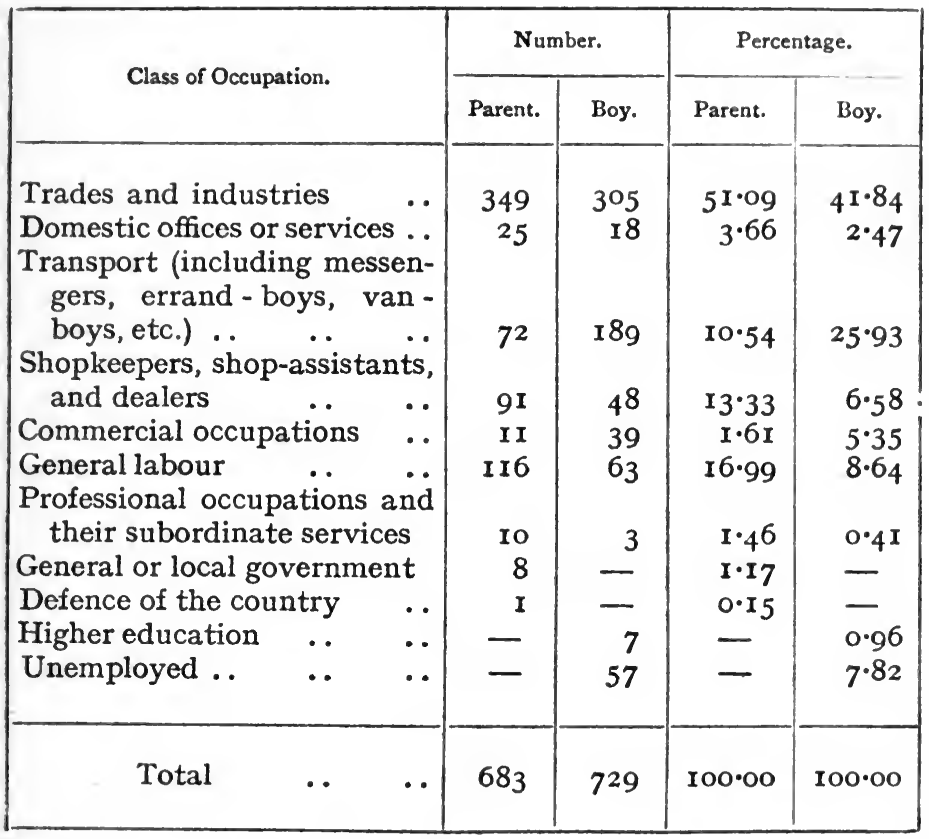

industries. Table IV. includes the collective results of the three preceding tables, and may be taken as fairly typical of London as a whole. It was necessary to exclude the returns of a few schools as incomplete, indefinite, or obviously inaccurate. Parent stands for occupation 
of parent, boy for occupation of boy. The two do not quite correspond, as in a certain number of instances the occupation of the parent was unknown. I have included the telegraph-boys under " Transport," as for my purpose this classification was the more suitable.

\section{TABLE IV.}

\begin{tabular}{|c|c|c|c|c|}
\hline \multirow{2}{*}{ Class of Occupation. } & \multicolumn{2}{|c|}{ Number. } & \multicolumn{2}{|c|}{ Percentage. } \\
\hline & Parent. & Boy. & Parent. & Boy. \\
\hline Trades and industries & $x, 308$ & 803 & $41 \cdot 46$ & $22 \cdot 31$ \\
\hline Domestic offices or services .. & 62 & $9 I$ & I.97 & $2 \cdot 53$ \\
\hline $\begin{array}{l}\text { Transport (including messen- } \\
\text { gers, errand - boys, van - }\end{array}$ & & & & \\
\hline boys, etc.) .. & 333 & $x, 368$ & ro.55 & $38 \cdot 00$ \\
\hline $\begin{array}{l}\text { Shopkeepers, shop-assistants, } \\
\text { and dealers }\end{array}$ & 328 & 307 & 10.30 & $8 \cdot 52$ \\
\hline Commercial occupations & 252 & 337 & $7 \cdot 98$ & $9 \cdot 36$ \\
\hline General labour & 696 & $33^{2}$ & $22 \cdot 06$ & $9 \cdot 22$ \\
\hline $\begin{array}{l}\text { Professional occupations and } \\
\text { their subordinate services }\end{array}$ & 68 & Io & $2 \cdot 16$ & $0 \cdot 28$ \\
\hline General or local government & 100 & I5 & $3 \cdot 17$ & $0.4 \mathrm{I}$ \\
\hline Defence of the country & 8 & 6 & 0.26 & $0 \cdot 16$ \\
\hline Higher education ... & - & IIO & - & $3 \cdot 05$ \\
\hline Unemployed .. $\quad \ldots$ & - & 222 & - & $6 \cdot 16$ \\
\hline Total & $3, I_{55}$ & 3,601 & $100 \cdot 00$ & $100 \cdot 00$ \\
\hline
\end{tabular}

In the interpretation of these tables certain facts must be borne in mind. None of the parents are returned as unemployed; this is because the trade of the parent was asked for, and no account was taken as to whether he was or was not employed. Secondly, the occupations 
are somewhat vaguely described; this in particular is true of the term "labourer." More exact information would no doubt have removed the parent from the class "general labour," and placed him in the class " transport," and occasionally in the classes " domestic servant" or "shop-assistant." Thirdly, the messenger-boys are included partly under "transport" and partly under "shop-assistants," the boy being termed sometimes an errand-boy and sometimes a shop-boy. The term " office-boy," which appears frequently in the returns, is vague. I have classed the office-boy as an errand-boy unless the school return places him in the column " skilled employment," when I have included him under the heading " commercial occupation."

Making allowance for a certain inevitable inaccuracy which belongs to returns of this kind, we have a general picture, accurate in all essentials, of the distribution of boys among the various forms of occupation immediately after leaving the elementary school. The columns which refer to the trade of the parents, and indicate therefore the distribution of the parents among the various forms of occupation, are of considerable value. If we take Table IV., which may be regarded as typical of London as a whole, and compare the last two columns, we shall at once notice the striking difference that marks the distribution of boys and of adults among the several kinds of employment. In " trades and industries," $4 \mathrm{I}$ per cent. of parents are engaged, and only 22 per cent. of boys ; 38 per cent. of the boys are engaged in " trans- 
port," and only ro per cent. of parents. This fact carries with it a conclusion of great importance-son and father can seldom work together. If, for example, Io per cent. of the parents are included under " transport," and 38 per cent. of the boys, it is clear that little more than a quarter of such boys can be employed in company with their parents. The actual facts, as revealed by an examination of the individual returns, are much stronger, and demonstrate the extreme rareness of father and son following the same occupation. In the case of "trades and industries" the trade of father and son is not infrequently the same ; this is in particular true of " tailoring " trades of the East End, included in Table III., where the proportion of adults to boys are as fifty-one to forty-two. In suburban villadom, pictured in Table III., the clerk is often father to the clerk, while the son of a shopkeeper occasionally assists his parents in the shop. The coster habit likewise runs in families. But with these exceptions father and son do not work together. In consequence, in his first situation the boy is cut adrift from the home and its control, such as it is. He has not his father by his side to note and guide his conduct; and if he enters a skilled trade, he lacks the personal interest of the parent to guarantee his satisfactory training. We have already seen that the school supervision is at an end; in consequence, the only disciplinary influence left is the influence of the employer. The character of the employment and the nature of the supervision of the master become, therefore, of supreme importance to 
the well-being of the boy. It is consequently necessary to examine in some detail the distinguishing features of the various kinds of occupation. They are usually roughly classed as skilled or unskilled, according as they do or do not lead to a form of employment which requires specialized skill or specialized intelligence.

The Unskilled Trades.-Practically the whole of the unskilled trades are included under the terms " domestic service," " transport," "shop," and "general labour," and the great majority of the boys who select these occupations may be said to select an unskilled trade. In Table I., a typical working-class district, it will be seen that 66 per cent. of the boys who leave the elementary schools come within this class. In Table II., a suburban area, the figures are 55 per cent.; but a considerable proportion of those included under "shops" appear to be employed in the shops of their parents, and to be learning the business. In Table III., representing the small East End trades, the figures are 44 per cent.; but, judged by wages and conditions of employment, the majority of the 42 per cent. included under trades should be transferred to the class of unskilled work. For all the districts, as a whole typical of London, Table IV. shows the figures to be $58 \cdot 27$ per cent. The figures quoted above ignore the boys returned as unemployed and unknown, the number of these for all London being 6 per cent. They are boys waiting for something to turn up; what will turn up it is impossible to predict. But it is safe to say that a considerable portion will drift into unskilled work. 
The unskilled trades fall into three classes. The first and smallest is included under " domestic service." Under this head are found boys in barbers' shops, page-boys, club-boys, boot and knife boys. Employment in a barber's shop is notoriously unhealthy ; a barber's shop is also supposed to be not infrequently the resort of the betting fraternity. The fortunes of the page and club boy await the zeal of an investigator; the knife and boot boy soon passes to some other occupation. Of the three classes, domestic service is the least important and the soonest left by the boy.

The second class, included under " transport" and " shopkeepers," is far the largest and the most important. In all London some 47 per cent. of the boys are found here; or, if we add a half of the 6 per cent. returned as unemployed, we may say that half the boys who leave the elementary schools belong to this class. It is necessary to take "transport" and " shopkeepers" together, because it is impossible to tell whether a "shop-boy" is merely an errand-boy, or a boy on the road to become a properly trained shop-assistant. It is probable, however, that only a small number could be regarded as future shop-assistants.

Ignoring these exceptions, we have to follow the fortunes of 50 per cent. of the boys leaving school-in other words, of $\mathrm{I}_{5}, 000$ persons. Their forms of employment have much in common. In the first place, they

1 L.C.C. Report of Medical Officer (Education), 1906, p. 23, showed that this was the most injurious form of work in which school-children were engaged. 
are what is known as " blind-alley" occupations-they lead nowhere. Boys only are engaged, and when the boys become men they are cast adrift. Sometimes they are absorbed in the adult service, but more usually, if they have not already left, are given notice, and must at the age of eighteen seek out some new way of earning a living. The report of Mr. Cyril Jackson makes this fact abundantly clear." "The industrial biographies received," he says, " show clearly that there is generally a time of transition when boys have to seek new occupations, for which they have little aptitude." 2 Or again : "There appears to be no doubt that the restlessness of many of the boys doing more or less unskilled work obscures from some employers the fact that they are using a greater number of boys than can ever be employed in connection with their trade as men. The employers who have filled up forms often state that they ' never dis. charge a boy who is willing to stay,' or 'that boys are only discharged for misconduct,' when it is evident from the figures appearing in the same form that there must be a considerable proportion of the boys passing out of the trade each year... That many employers, on the other hand, do in fact discharge a considerable proportion of their boys because they have no room for them as men-or, to express the same thing in the form in which it presents itself to the masters, because they cannot afford to offer men's wages-is shown in the short

1 Report of Mr. Cyril Jackson on Boy Labour, prepared for the Poor Law Commission.

${ }^{2}$ Report on Boy Labour, p. 7 . 
accounts of the trades in the Appendix." 1 It is needless to labour the point further, as everyone familiar with the conditions of boy work give evidence to the same effect.

The second characteristic of these trades is that they are mainly concerned with fetching or carrying something-messages, letters, parcels. It is characteristic of that stage of civilization at which we have arrived that we want to save ourselves trouble, or to save ourselves time. Boys are the instruments we use. "Here we are, all of us," says a modern writer, "demanding an endless number of tiny jobs to be done on our behalf. Every year multiplies these demands, increasing the pace at which the jobs can be done, and the number of them that can be crowded into the time. We learn to expect more and more conveniences at our elbow by which communication can be made, business transacted, messages despatched, parcels transferred, news brought up to date, transit hastened, things of all kinds put under our hand. We touch buttons, press knobs, ring bells, whisper down telephones, keep wires throbbing with our desires, bustle and hustle the world along. And all this in the end means boys. Boys are what we set moving. Boys are the material in which we deal. Boys are our tools. Every wire has a boy at the end of it." 2

This tendency to demand the services of boys has spread through all classes of society. To take a single example of quite recent growth : It is becoming less and

1 Report on Boy Labour, pp. 7 and 8.

2 Canon Scott Holland, Introduction to "The Problem of Boy Work," by the Rev. Spencer J. Gibb. 


\section{APPRENTICESHIP OF TO-DAY}

less common for the housewife to bring the results of her marketing home herself; a boy delivers the goods instead. Go into any shop, even in the poorest part of the town, and make a few purchases; the shopman will probably offer to send them home for you. There is something flattering and pleasant in the offer; it is one of the new products of competition to multiply conveniences instead of cutting prices. The demand for boys is rapidly increasing; and while the demand is increasing, the supply of boys has diminished. The raising of the school age, the improved attendance, and the decrease of truancy, have all removed from the labour market an immense number of boys. "The Census figures show that there has been a steady diminution of boys employed under fifteen during the last quarter of a century." 1 The Labour Exchanges testify to the same effect, the managers frequently saying: "There is an unsatisfied demand for juvenile labour of an unskilled type." 2 This growing demand has two effects. First, as it becomes increasingly easier for boys to obtain situations, there is less and less inducement for them to show such industry and good conduct as are necessary to retain their places. Dismissal has no terrors; it means, if they please, a few days' holiday, or, if they prefer it, a new employer can be at once discovered. It becomes therefore difficult for an employer to exercise over the boys the discipline they need; if he attempt to do so, he

1 Report on Boy Labour, p. 4.

2 Report of the Departmental Committee on the Employment of Children Act, 1903, I910, p. I4. 
will soon find himself without boys. Lads change situations for the mere sake of change, to see what happens. "I have known," says Mr. J. G. Cloete, "boys who, within three years of leaving school, have been employed in as many as seventeen different occupations." 1 The second consequence of the increased demand for boys in these kinds of occupations is a rise in wages. The earnings of these boys are considerably higher than those obtained by a boy who enters a skilled trade. "The casual and low-skilled employments give higher wages in the early years in order to attract the boys." 2 With boys choosing. as they do, their own occupations, high wages at the outset are more attractive than low wages with the prospect of learning a trade.

The third characteristic these occupations have in common lies in certain general conditions of employment. Hours are long; at the same time, the boy is often idle for long periods, waiting for messages to come in and parcels to go out. Shop-boys and telegraph-boys are kept hanging about with nothing to do. The officeboy in a small office is often the whole staff, and is left alone for hours when his master is out, and "spends his time either in vacancy, in mischievous expeditions along the corridor, or in reading trash of a bloodthirsty nature." 3 The boy has often heavy goods to carry long distances, and overtaxes his strength. Either

1 " Studies of Boy Life," p. xIx.

2 Cyril Jackson, Report on Boy Labour, p. I4.

3 The Rev. Spencer J. Gibb, "The Problem of Boy Work," p. 33 . 
there is too much idleness or too much work; these are the alternatives. In neither case is there the possibility of much supervision.

The fourth characteristic has not received the attention it deserves. These forms of occupation, though unskilled in the sense that the boy receives no training in his present place of business, nevertheless demand qualities of a high standard. The boy must be regular, obedient, and, above all, intelligent. A dull boy as a messenger is liable to make stupid and irritating mistakes. The stories of district messengers carrying letters unaided over the Continent show that the boys possess no ordinary intelligence. Now, we have already seen that these are the qualities which are in a peculiar degree the product of the elementary schools. The schools turn out innumerable boys of this kind. It is not, perhaps, a mere coincidence that the increasing use of boys in occupations which call for alertness of mind has gone on side by side with improvements in the educational system. The State has spent much money on these boys. A boy who starts to attend school at the age of three and leaves at fourteen has had spent on him a sum of money which, if invested year by year at 4 per cent., and left to accumulate till the time for leaving school comes, would amount to nearly $£$ Ioo. Each year in the 30,000 boys who leave school $£ 3,000,000$ of State-created value is turned adrift. The State has therefore a right to demand that this capital sum of $£$ roo invested in the boy shall not be squandered by the 
employer. He ought to give back at the age of eighteen at least as valuable an article as he received four years earlier.

This consideration leads to the last characteristic distinguishing these occupations. They lead to nothing, and when the boy reaches the end, he is, in the majority of cases, distinctly inferior in every way to what he was three or four years before. Evidence in favour of this assertion is overwhelming. "At the present time, at the age of eighteen, after a four years' course of employment, whose chief characteristics are the long hours, the lack of supervision, and the total absence of any educational influence, the lad is a distinctly less valuable article in the labour market than he was when he left school four years previously. His only asset is represented by greater physical strength, accompanied probably by a marked decrease in general health and vigour. $\mathrm{He}$ has lost the intelligence and aptitude of the boy, and remains a clumsy and unintelligent man, fitted for nothing but unskilled labour, and likely to become sooner or later one of the unemployed." " "There seems little doubt that the boy labour is used up for industrial purposes, and that they are left less capable members of the community, with little prospect of good work when they become adults." 2 "The most hopeless position is that of the errand-boy at a small shop in a poor neighbourhood;

1 Report on the Apprenticeship Question, Minutes of the Education Committee of the London County Council, February 24, 1909, p. 424.

2 Report on Boy Labour, p. 27. 
his prospects are absolutely nil."1 " The chart prepared from the forms filled in by boys who entered life as errand-boys shows that the small proportion who find steady and skilled employment afterwards have ceased to be errand-boys very early; the vast majority become workers in low-skill trades, or general and casual labourers." 2 "Mr. Courtney Terell, who has been making inquiries from the Passmore Edwards Settlement, writes: "I feel confident... that the messenger work produced a definite effect on the boys, as will the continual performance of any one of a definite function which admits of no improvement, and that this has unfitted them for other work." "3 "The injury done to these boys is not that they are compelled as men to devote themselves to low-skilled labour, but that from the more or less specialized nature of the work which has employed this boyhood, they are unfitted to become good low-skilled labourers." 4

It is impossible to resist the mass of evidence of this kind which might easily be increased indefinitely. The boy gains nothing from this form of employment and loses much. He loses the results of his training in the elementary school; the habits of obedience, regularity, and industry are dead ; the bright intelligence is dulled, and with the coming of dulness goes the power of learning. He loses his prospects; his future is the future of the unskilled labourer - the unskilled labourer, robbed of

${ }^{1}$ Mr. Cloete, in "Studies of Boy Life," p. 125.

2 Report on Boy Labour, p. 20.

3 Ibid., p. $20 .{ }^{4}$ Ibid., p. 26. 
that grit and alertness which alone secure for unskilled labour the adequate reward of permanent employment at a steady wage. His loss is the loss of the community, which is compelled later to relieve him and his family, and perhaps in the end find a home for him in the workhouse. And in thinking of this deterioration, and of that hopeless future which that deterioration involves, we must never forget that it is not a mere handful of lads who suffer in this way, but that half the boys who leave the elementary school start on this dreary journey, and, so starting, bid fare to reach that dreary end.

Reckoned in money, the State has spent a million and a half on these boys, and but little comes back to the State or remains with the boy. If it has gone anywhere, and it probably has, then it has gone into the pockets of the employers who have sucked out of the boys their value, and then cast them aside as worthless refuse, a sort of slag or waste product of their works, for which neither they nor anyone else can find a use. In saying this there is no desire to censure unfairly the employers. They are undoubtedly to blame, because thoughtlessness and ignorance in persons of their position are always blameworthy; but there is nothing deliberate in their actions, and they are largely unconscious of the harm they are doing. There is no active cruelty, and often much rude and ready kindness. The boys to them are merely instruments in the machinery of their business, for the moment the cheapest instruments that can be found, to be used until a new and better supply takes the place of those who are 
used up. They are ignorant of the consequences of their conduct, and, as their evidence shows, generally imagine that the boys who leave find suitable jobs. It is only of late years that numerous investigators and managers of boys' clubs have revealed the grave results of this thoughtlessness. Employers who generally enjoy a good reputation as employers are often the worst offenders. Indeed, the most flagrant example of this exploitation of boy labour is to be found in the Imperial Government and the Municipal Service. Mr. Cyril Jackson has in his report devoted much space to the telegraph-boys in the service of the Post Office. "The boys come frum very good homes, and are often the pick of the family. They are examined medically, and bring characters." 1 A mere fraction are absorbed in the adult service. "It appears as if the Post Office is one of the least promising occupations into which a boy can enter. The better boys go into it, and it is very depressing to see from our returns how very few of the very large number discharged at sixteen or seventeen get into as good employment as their good social standing and general standard of education should have guaranteed for them."2 "Everyone of experience seems to agree that these telegraph-messengers who are discharged exemplify in a very striking way the evils of a parasitic trade." ${ }^{3}$ Yet these things had been going on for years in a service like that of the Post Office, which is subject to much criticism by its employees,

1 Report on Boy Labour, p. I7.

2 Ibid., p. r6. ${ }^{3}$ Ibid., p. I7. 
and yet no attention had been called to the evil. Unfortunately, boys have no votes, and do not form trade unions. Other Government departments and the Municipal Service seem no less ignorant and no less worthy of blame. A short time back the Education Committee called the attention of the London County Council to the misuse of its boy labour, and now the Council allows its boys, weekly, six hours " off" during working hours, and provides classes which they are compelled to attend. At the same time it has nominated one of its officers to look after the interests of these boys, and to guide them into useful occupations.

If the public service is thus guilty, we must not be surprised that private employers are not conscious of wrongdoing in their use of boys. The evil is now revealed; there can be no further excuse for ignorance. How to deal adequately with the problem must be left to the consideration of the next chapter.

The third division of the unskilled occupations comes under the head "General Labour." Some 9 per cent. of the boys as they leave school fall into this class. This is a nondescript class not clearly defined in the returns. Probably a considerable proportion should be brought into the preceding class, but there are evidently a large number who could not be disposed of in this way. Boys employed in warehouses, in gardens and parks, boys in small places assisting the master in the lighter forms of labour, boys accompanying their fathers and joining in his work-these come into this division. The returns are 
not sufficiently explicit to yield materials for a critical examination; but one or two conclusions can be derived from their examination. It will be seen that 22 per cent. of the parents, as compared with 9 per cent. of boys, are recorded as being general labourers. There is here no excess of boys ; there should not be the same difficulty in boys finding openings in the adult service as in those occupations where boys can claim a practical monopoly. Boys have always taken some part in labouring work, and so passed to the better class of unskilled labour. Boys in warehouses, for example, frequently find there permanent situations. Further, the proportion of parents to sons would indicate the possibility of the two being employed together, and the boy thus remaining under the supervision of his father. An examination of individual returns justifies this conclusion. On the other hand, it is to be remembered that the hours of employment are frequently very long, and the work arduous and ill suited to the strength of a growing lad, and in no way regulated by legislation. Taken as a whole, it is probable that the boys who enter this kind of occupation, though without opportunity of continuing their education, are not in as forlorn a condition as those in the previous class. But the whole question is obscure, and it is difficult, without fuller information, to test the nature of their training.

The Skilled Occupations.-The skilled occupations fall into two classes-those where manual skill is required, and those concerned with commercial and clerical operations. The former are included under "Trades and 
Industries," and the latter under " Commercial Occupations," "Professional Occupations," and " Local Government."

I. Trades and Industries.-From the tables printed on pp. II5-II8, it will be seen that under this heading there are in Table I., the type of a working-class district, $4 \mathrm{I}$ per cent. of parents and I9 per cent. of boys; in Table II., the type of a suburban district, the figures are 36 and 15 respectively; in Table III., the type of the small trader of the East End, $5 \mathrm{I}$ and 42 ; while in Table IV., the type of London as a whole, the percentage is in the case of fathers $4 \mathrm{I}$, and in the case of boys 22 . We have now to consider the prospects as regards supervision, training and opening which these trades offer to the boys who enter.

Table III., with its percentage of 5 I parents and 42 boys engaged in trades and industries, presents a pleasing appearance, but the bulk of the trades concerned belong to the tailoring and other industries where sweating is rife, where the skill required is of a low order, and the wages small and often below the level of bare subsistence. The boys learn something, are frequently employed with their fathers, and have a more or less permanent outlook, though within the horizon of that outlook is seldom included the vision of a living wage. They in general do not form part of the class which finds its way into the ranks of that miscellaneous unskilled labour whose chief characteristic is casual employment.

Ignoring this table, and taking the table for all London, 
we find again the great disproportion of boys and parents. There are two ways in which the boys may learn. They may become indentured apprentices, or, engaged only by the week, though sometimes still termed apprentices, they may enter the workshop, and take what chance is afforded them of " picking up" the mysteries of the trade.

(a) Indentured Apprenticeship.-Apprenticeship is of little importance in London; the system is rapidly becoming obsolete. Whether this is desirable is a matter of opinion; that it is a fact cannot be gainsaid. All evidence is unanimous in support of this conclusion. In 1906 a special committee was appointed by the London County Council to make inquiries into the question, and, after careful investigation, reported that "in London the old system of indentured apprenticeship has for many years been falling into decay. In the majority of the industries it has almost entirely disappeared; in others it is occasionally found existing in a haphazard and highly unsatisfactory manner; while in only a few trades can it be said to be the commonly recognized way of entering the profession." 1 There are in London various charities, with an income of about $£ 24,000$ a year, which, in accordance with the terms of their trusts, might be used for purposes of apprenticeship; "but not more than a third of the income has been devoted to this purpose." "The fact that so small a fraction of the income has been devoted to apprenticeship indicates that the trustees have

1 Report on the Apprenticeship Question, p. x. London County Council Publications. P. S. King and Son. 
not found it an easy task to find candidates anxious to be indentured to one of the skilled trades." 1 "The recurring note," says Mr. Charles Booth, "throughout the whole of the industrial volumes of the present inquiry is that the system of apprenticeship is either dead or dying." 2 The numerous letters to the Press, the wealth of speeches on the matter, the sundry public meetings presided over by all manner of persons, from the Lord Mayor downwards, all voice the same opinion. It is needless to labour the question; we may take it as an accepted fact that in London indentured apprenticeship is obsolescent, and the system itself of negligible value as a factor in the training of youths in the process of skilled trades.

(b) Picking up a Trade.-Here a boy enters a workshop, and takes his chance of learning the trade from watching and assisting the men. The employer is under no agreement to give him instruction-least of all, to make an allround craftsman of him. The boy rarely acquires more than a certain dexterity in the performance of a single operation; and, however proficient he may become in that operation, his general intelligence and skill suffer. from a narrow and exclusive specialization. The system and consequences are dealt with at length in the Report of the London County Council already mentioned. The importance of the problem must be the justification for a long quotation :

1 Report on the Apprenticeship Question, p. 2.

2 Charles Booth, "Life and Labour of the People," vol.ix., p. 222. 
"The high wages a lad can earn as an errand-boy . . . are more attractive than the low wages associated with an industrial training. Earning looms larger in his imagination than the laborious and less remunerative learning. ... Even if, on leaving school, he obtains employment in a workshop, his prospects may not be materially improved. As an errand-boy running in and out of the workshop, if possessed of aptitude and sharpness, he may in a haphazard fashion pick up a smattering of the trade. If he is taken into the shop as a learner, he has little chance of getting an all-round training. $\mathrm{He}$ is frequently out of work, and even when employed seldom learns more than a single operation. The Advisory Committee of the London County Council Shoreditch Technical Institute ${ }^{1}$ recently held an exhaustive inquiry on the subject, and some of the conclusions are so germane to the present question that they merit quotation. 'It is thus possible,' they write, 'for a boy to be at one branch of a trade for a few months only, and when bad trade intervenes he is thrown out of employment, and frequently finds himself at twenty years of age without a definite knowledge of any craft whatever, and he swells the ranks of the unemployed. We have it on the authority of foremen, employers, apprentices, and parents, that very little opportunity exists, even in big houses, for a boy to learn his trade thoroughly; indeed, we have had students who have been in a workshop as appren-

1 This Advisory Committee contains representatives of the chief woodwork industries of the district. 
tices for three or four years who could not make a small drawer, and in many cases who could not square up true or make the usual joints; and in the woodworking trade their knowledge of drawing when they come to us is practically nil. It is a rare thing to find a young workman who can attack any branch of his trade successfully. It frequently occurs that, in consequence of extensive subdivision of labour and excessive competition, a man or boy is set to do one thing-e.g., music-stools, overmantels, chair-legs, sideboards-all the time. It is true the man or boy becomes skilled in one direction, but correspondingly narrow in a true appreciation of his trade. It is also a frequent occurrence that a master who has a job on hand which is slightly out of the usual run finds it impossible to put it in the hands of his usual staff. Moreover, when work of delicate design and construction has to be made from specified drawings, it is extremely difficult to obtain men who can proceed with the work on their own responsibility. Not only do these remarks apply to the woodcrafts generally, but they apply with equal force to such work as upholstery (both stuffing and drapery), to metal-work, and to carving. In connection with the latter subject, it is a rare thing indeed for carvers to design a carcass in the rough, and then to see whether the proposed carved portion is in harmony with the whole -whether the said carving be too much in relief, too flat, too expansive, or altogether out of character with the general work. It is notorious that guod polishers and furniture decorators are exceedingly rare, and many a 
high-class manufacturer has his goods spoiled on account of bad polish and decorative treatment." "1 It must be remembered that this last quoted opinion is not the opinion of the amateur, but the informed opinion of representative employers.

The woodwork and furniture trades are not peculiar in the characteristic of inadequate training. "We have reason to believe," continues the Report, " that if a similar inquiry were made into other trades, the same unsatisfactory picture would be disclosed. Either the training is one-sided, or there is no training at all. The consequences are sufficiently obvious. The skilled trades are, we fear, recruited in the main by immigrants outside London. In many trades the Londoner is at a discount. Acquainted as he is with but one or two operations of his industry, if he loses his situation, it is only with the greatest of difficulty that he can find another. Mr. Charles Booth states that ' with carpenters and joiners, bricklayers, carriage builders, engineers, smiths, and saddlers, the percentages of heads of families born out of London range from 5I to 59.' An inquiry made of the Technical Board of the London County Council on the Building Trades in I858 showed that ' $4 \mathrm{I}$ typical firms in various branches of the building trades having I2,000 employés had only 80 apprentices and 143 learners, instead of $I, 600$, which would have been the normal proportion.' The same Report mentions that 'among the foremen and operatives who have come before us, not one stated that

1 Report on the Apprenticeship Question, p. 4. 
he was born or trained in London.' In these trades the better positions go inevitably to the country-bred man, with his all-round training. In the docks alone does the Londoner hold his own. An inquiry there showed that among the dock-labourers proper more than 72 per cent. were born in London-a result not calculated to excite any very solid satisfaction. These facts should arouse serious apprehension concerning the future of the Londonbred citizen. We cannot view with equanimity his relegation to lower positions, while the better places are given to better-trained immigrants. We are not prepared to admit that the Londoner is, on the average, inherently inferior either in intelligence or manual dexterity to his country-born neighbour."1

These quotations indicate clearly the general aspects of the situation. They show the small prospects boys enjoy who enter a skilled trade in London. Parents are not blind to the condition of affairs, and it is not unnatural on their part to allow the boys to go out as errand-boys, where at least the immediate earnings are larger and the hope of advancement not much more discouraging.

2. Clerical and Commercial Occupations.-Including under this head commercial and professional occupations, and general or local government, we find in Table I., the type of a working-class district, $6 \frac{1}{2}$ per cent. of parents and 8 per cent. of boys; in Table II., the type of the suburbs, 30 per cent. of parents, and $16 \frac{1}{2}$ per cent. of boys ;

1 Report on the Apprenticeship Question, p. 4. 
in Table III., typical of the East End, 4 per cent. of parents, and 6 per cent. of boys; in Table IV., typical of London as a whole, I3 per cent. of parents, and ro per cent. of boys. In the school returns no boy was placed under these headings unless he appeared in the column "Skilled Work." In judging of these results it must be borne in mind that the better positions fall to those who have had at least a secondary education. Nevertheless, clever boys, who attend evening schools, have some prospects of advancement. One feature in the returns was the large number of boys who were apparently employed with their fathers. In many instances boys obtain their positions as the result of examination. This is true of several banks, assurance companies, railway companies, and is becoming the general practice in the Civil and Municipal Service. Many of these examinations are within the standard of attainment reached by the cleverer boys in the elementary schools. The boys at their place of employment are taught sufficient to enable them to do the work allotted them. This is often of a specialized character; and without further education they cannot expect to escape from the lowest ranks of clerks. If well conducted, they can probably obtain a permanent position when manhood is reached, or, at any rate, are not discharged because they have become men. Change in the methods of business, or failure of the concern, may entail dismissal ; and after dismissal a new position is not easily obtained. But the lower ranks of the clerical profession are ill paid, and the need to present a good appear- 
ance makes serious inroads on the meagre stipend. Unless the boy continues his education and means to rise, his outlook is not very encouraging. He has, however, the advantage of supervision, of relatively short hours, and enjoys the possibilities of attendance at evening schools. In spite of what is often said to the contrary, taking things as they are, he has the best prospects of those included in the returns. The fact that so large a proportion of boys coming from the suburbs is found in this class would seem to indicate that the more thoughtful parents share this opinion.

\section{(c) The Passage to Manhood.}

The tables quoted on pp. II5-II8, and founded on school returns, refer only to the first occupations of boys as they leave school. It is unfortunate that no figures exist which trace year by year the later careers of the boys. All persons, however, who have any intimate knowledge of the subject agree that the boys repeatedly move in an almost aimless fashion from one situation to another.

The census returns indicate in a general way the distribution, among the trades and occupations, of persons of various ages. They do not, however, give us a yearly survey ; and after the age fourteen to fifteen we are compelled to rest content with figures which cover periods of five years. The following table is taken from a table printed in a Report to the Education Committee of the London County Council, made by a special committee 
appointed to deal with the apprenticeship question; it is founded on the Igor census return :1

\section{OCCUPATIONS OF BOYS AND MEN.}

Percentages.

\begin{tabular}{|c|c|c|c|c|}
\hline Class of Occupation. & Age $14-15$ & Age 15-20. & Age $20-45$. & Age $45-65$. \\
\hline Trades and industries & $14 \cdot 74$ & $31 \cdot 54$ & $35 \cdot 76$ & $38 \cdot 85$ \\
\hline Domestic offices or services & $\mathrm{I} \cdot 75$ & $3 \cdot 29$ & 3.55 & $3 \cdot 35$ \\
\hline $\begin{array}{l}\text { Transport (including mes- } \\
\text { sengers, errand-boys, van- }\end{array}$ & & & & \\
\hline boys, etc.) $\quad \ldots \quad \ldots$ & $27 \cdot 65$ & $19 \cdot 49$ & $16 \cdot 04$ & $14 \cdot 19$ \\
\hline $\begin{array}{l}\text { Shopkeepers, shop-assist- } \\
\text { ants, and dealers.. }\end{array}$ & $6 \cdot 03$ & & $14.5 \mathrm{I}$ & 9.23 \\
\hline Commercial occupations .. & $4 \cdot 61$ & II.5O & $9 \cdot 55$ & $12 \cdot 40$ \\
\hline General labour $\quad \ldots \quad \ldots$ & $x \cdot 46$ & 5.53 & $8 \cdot 46$ & $7 \cdot 02$ \\
\hline $\begin{array}{l}\text { Professional occupations and } \\
\text { their subordinate services }\end{array}$ & $0 \cdot 73$ & $2 \cdot 00$ & 4.55 & $5 \cdot 08$ \\
\hline $\begin{array}{l}\text { General or local government } \\
\text { of the country (including } \\
\text { telegraph-boys) .. }\end{array}$ & & & & \\
\hline Defence of the country .. & $0 \cdot 15$ & $r \cdot 77$ & $\begin{array}{l}3.40 \\
1 \cdot 40\end{array}$ & 0.62 \\
\hline $\begin{array}{l}\text { Without specified occupa- } \\
\text { tion or unoccupied (in- } \\
\text { cluding boys at school) .. }\end{array}$ & $39 \cdot 87$ & $9 \cdot 83$ & $2 \cdot 48$ & $7 \cdot 02$ \\
\hline Total number analyzed .. & $4^{I, 889}$ & $208,92 \mathrm{I}$ & 869,466 & 313,949 \\
\hline
\end{tabular}

In comparing this table with the tables founded on the school returns, it must be borne in mind that this table is not confined to persons who have passed through the elementary schools, but refers to all the inhabitants of London.

1 Minutes of the Education Committee, February 24, 1909, p. $4^{\mathrm{I}} 5$. 
The most striking feature in the table is the marked difference in the distribution of occupations at the age of fourteen to fifteen, and at other ages. The third column, which includes persons between the ages of twenty and forty-five, covers the period of a man's greatest vigour, and may be regarded as the normal or stable distribution. Comparing the first and the third column, it becomes obvious that the first year, at least, after leaving school is a year of uncertainty and aimless wandering. The boys have not definitely chosen any particular occupation as their life's work. How long is spent in this state of unprofitable drifting the census returns do not show as the following years are not separated. But the fact that the distribution in the second column differs materially from the normal distribution of the third column would seem to indicate that this period stretches some distance into the years that lie between the ages of fifteen and twenty.

In default of this general information, we must fall back on special investigations; and here the facts are drawn from too narrow a circle of inquiry to be regarded as altogether typical. In his report to the Poor Law Commission, Mr. Cyril Jackson gives an instructive table ${ }^{1}$ (see p. I45). It is founded on biographies of boys obtained from boys' clubs, schoolmasters, and managers of schools.

I have omitted the ages that follow, as the number of boys concerned was too few to justify any conclusions, The rapid diminution in the number of boys when the age of eighteen is reached impairs the value of the last

1 Report on Boy Labour, p. 47. 
two columns. In general, the districts from which the boys are drawn are poor ; but the fact that the boys come into relation with various organizations, and were no doubt assisted by them, should lead us to believe that the picture presented errs, if anything, by being too favourable. The steady increase in the trades, and the

PERCENTAGE OF BOYS IN VARIOUS GROUPS OF OCCUPATIONS AT EACH AGE.

\begin{tabular}{|c|c|c|c|c|c|c|}
\hline Occupations. & Age 14. & Age 15. & Age 16. & Age 17. & Age $x 8$. & Age 19. \\
\hline Skilled trades & II $\cdot 2$ & $I_{4} \cdot \mathrm{O}$ & $16 \cdot 8$ & $17 \cdot 8$ & $18 \cdot 0$ & $16 \cdot 3$ \\
\hline Clerks & $I_{4} \cdot 6$ & $15^{\circ} \mathrm{O}$ & $16 \cdot 4$ & $I_{5} \cdot 2$ & $\mathrm{I}_{5 \cdot 4}$ & $14 \cdot 3$ \\
\hline Low-skilled & $28 \cdot 2$ & $3^{2 \cdot} \cdot 8$ & $34 \cdot I$ & $33 \cdot 9$ & $32 \cdot 5$ & $34^{\cdot I}$ \\
\hline Carmen $\quad$. & $0 \cdot 6$ & $0 \cdot 2$ & 0.6 & $2 \cdot 6$ & $4 \cdot 5$ & $5 \cdot I$ \\
\hline Van-boys $\quad$. & $8 \cdot 2$ & $6 \cdot 6$ & $5 \cdot 2$ & $4 \cdot 9$ & $2 \cdot 8$ & $I \cdot 2$ \\
\hline Post Office .. & I. 4 & $I \cdot 4$ & $0 \cdot 2$ & $0 \cdot 2$ & $0 \cdot 3$ & $I \cdot 2$ \\
\hline Errand and shop & & & & & & \\
\hline $\begin{array}{c}\text { boys } \\
\text { General and }\end{array}$ & $30 \cdot 5$ & $22 \cdot 0$ & I8.4 & $\mathrm{I}_{5} \cdot \mathrm{O}$ & $12 \cdot 6$ & $10 \cdot 3$ \\
\hline labour $\quad$.. & $5 \cdot 3$ & $7 \cdot 0$ & $6 \cdot 7$ & $6 \cdot 9$ & $6 \cdot 4$ & $8 \cdot 7$ \\
\hline Army & - & 0.6 & $0 \cdot 6$ & $I \cdot I$ & $3 \cdot 6$ & $4^{\circ} \mathrm{O}$ \\
\hline At sea & 0.2 & $0 \cdot 4$ & $0 \cdot 8$ & $I \cdot 5$ & $2 \cdot 8$ & $3 \cdot 5$ \\
\hline Emigrants & - & - & $0 \cdot 2$ & 0.4 & 0.8 & $I \cdot 2$ \\
\hline Total No. of boys & 485 & 500 & 474 & $44^{8}$ & $35^{6}$ & $25^{2}$ \\
\hline Unemployed & I & 2 & I & I3 & 22 & 22 \\
\hline
\end{tabular}

equally steady decrease in the number of van-boys, Post Office boys, errand and shop boys during the first three years is instructive. Trades, skilled and low-skilled, reckoned in percentages, have risen from $39^{\circ} 4$ to $50^{\circ} 9$, while the messenger class has fallen from $40^{\circ} \mathrm{I}$ to $23^{\circ} 8$. The changes in the earlier years are the most significant. 
and little stability of occupation is reached before the age of eighteen. The age of fourteen evidently represents the year of greatest indecision and maximum drift.

In other parts of his report Mr. Jackson has endeavoured to follow the history of boys who have begun life as errand-boys or as van-boys. " From the forms returned," he writes, "it seems clear that the theory that boys can become errand-boys for a year or two, and then enter skilled trades, cannot be maintained. Very few boys can pick up skill after a year or two of merely errand-boy work." 1 Or again: "The chart prepared from the forms filled in by boys who entered life as errand-boys shows the small proportion who find any steady and skilled employment afterwards, and those have ceased to be errand-boys very early. The vast majority become workers in low-skilled trades or general and casual labourers." 2 Of all the "blind-alley" occupations, that of the van-boy appears the most deplorable. "The life of the van-boy is a rough and somewhat lazy one. They have long hours, spells of idleness, and considerable opportunities of pilfering and drinking." 3 "The chart shows that it is a very low grade of occupation, and that very few boys who begin as van-boys get into skilled tradesa far lower percentage, in fact, than errand-boys." 4

The second point to be noted in the table founded on the census returns is the large number-nearly 40 per cent.- - of boys of the age of fourteen returned as without

1 Report on Boy Labour, p. 20.

3 Ibid., p. 22.

2 Ibid., p. 20.

- Ibid., p. 23. 
specified occupation or unoccupied (including boys at school). There are in the elementary schools about 5,000 boys between the age of fourteen and fifteen, and probably about the same number in secondary schools. Converted into percentages, this 40 per cent. would be broken up into 24 per cent. at school and 16 per cent. without specified occupation. The last figure is high, and justifies the conclusion, not only that the boys of fourteen wander from occupation to occupation, but that they also are frequently doing nothing. The habit of shifting from situation to situation necessarily involves considerable periods of unemployment. Thus early in their career the boys become accustomed to the evils of casual labour.

We can arrive at the same conclusion by approaching the problem from a somewhat different point of view. If in some trades we discover an excess of boys, and in others an excess of men, it is clear that there must be shocks and shiftings in the passage from youth to manhood. In London the number of lads between the ages of fourteen and twenty is 17.5 per cent. of the number of males between the ages of fourteen and sixty-five. If, therefore, we find the proportion of lads to total males engaged in any trade, reckoned in percentages, differs much from 17.5 , either lads must at some time pass out of the trade or men come in. On the other hand, in a trade where this percentage is approximately 17.5 boys who enter have, at any rate, the chance of finding employment as men. In this sense we may regard the distribution of lads and men in a trade as normal 
when this percentage lies between I5 and 20 ; less than normal when it drops below I5; more than normal when it rises above 20. The following table may be taken as an example of trades in which considerable numbers of persons are engaged :

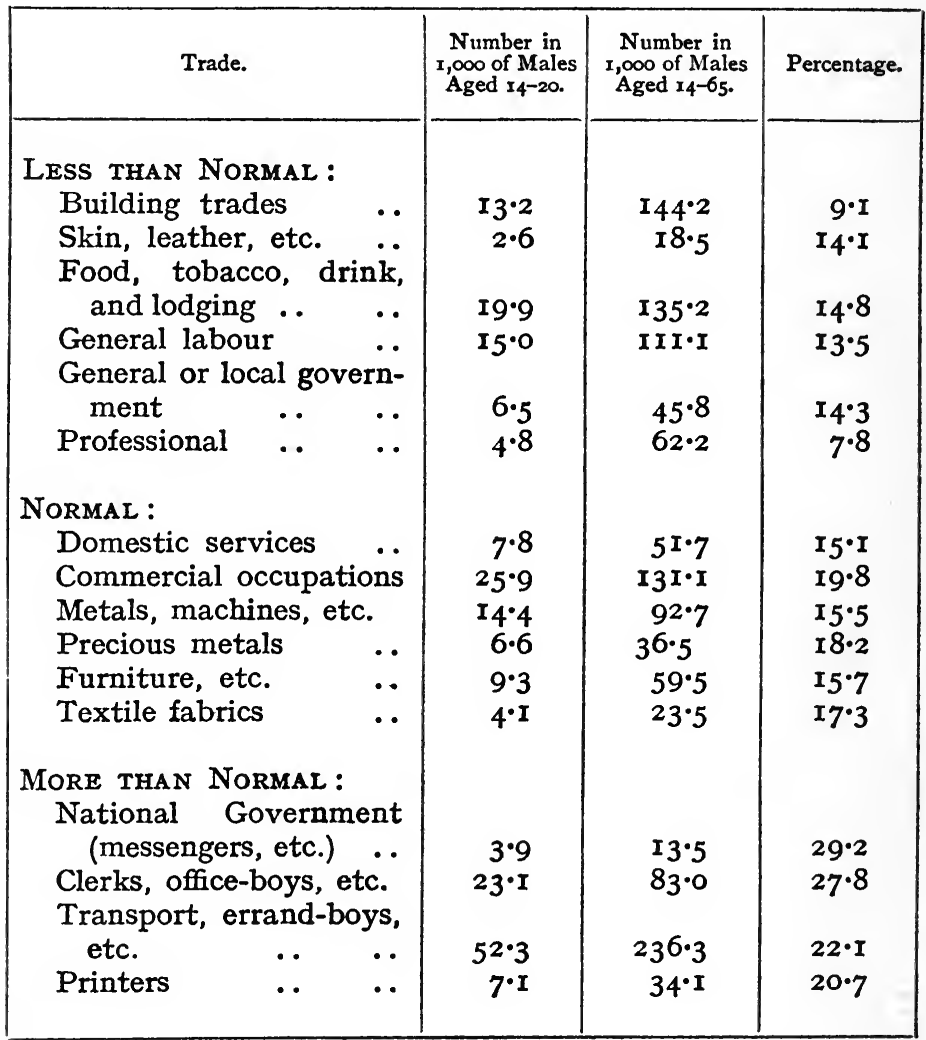

If we could have taken the period fourteen to eighteen instead of fourteen to twenty, these tables would have been even more striking than they are. But, even as they 
are, they are sufficient to enforce the lesson that between the occupation of the boy and the occupation of the man there is a gulf fixed. The one does not lead naturally to the other. When the boy becomes a man he does not find provided for him a natural opening; with more or less pains, he is driven to force a way in trades for which he has received no definite preparation, and in which diligence and good character do not afford any guarantee of success.

\section{(d) Summary.}

Before proceeding to examine the conditions of boy labour in other parts of the country, it will be desirable to summarize the results for London, and so to determine how far the essentials of a true apprenticeship system are found in that city.

Supervision. - The boy should be under adequate supervision until he reaches the age of at least eighteen. In London, so far as the majority are concerned, all State supervision ends at fourteen. When the boy goes out to work what measure of supervision was previously found in the home comes to an end ; it is beyond the power of parents to exert any real control over the boy. $\mathrm{He}$ is his own master, finds his employment for himself, and leaves it when he thinks fit. Philanthropic enterprise touches a fringe, and a fringe only, of the boys; their growing sense of independence resents restraint. The story of the workshop points the same moral. Personal relations between boy and employer are seldom possible; and where the demand for the services of boys is unlimited 
and unsatisfied, attempts to enforce discipline fail, because, sooner than submit, the boy seeks another situation.

Training.-For the unskilled labourer of the future London provides no training. The schools do, indeed, turn out in the boys ready made and completely finished articles for boy-work and "blind-alley" occupations. and three or four years of such employment destroy the mostmarked results of elementary education. The skilled workman of the future finds in the workshop small chance of gaining that all-round training which will make of him a man, and not a machine. Technical education for the minority is successful, but without power to compel attendance and limit the hours of boy-labour it is only the few who can avail themselves of the opportunities offered.

Opening.-Boys' work is separated from man's work, and there is no broad highway leading from the one to the other. The lad of eighteen is compelled to make a new beginning just when new beginnings are most difficult. His power of learning is gone from him, and in the unskilled labour market alone does he see any prospect of earning immediate wages. The State Labour Exchange is an infant which has yet to justify its creation.

In London the provision of supervision, of training, of an opening, is alike defective, and beyond the age of fourteen for the majority of boys can hardly be said to exist at all ; and, what is most serious, we are face to face with a state of affairs where there is no sign of improvement, and where all tendencies indicate for the future 
an accelerated rate of progressive failure. In short, London cannot claim even the beginnings of a real apprenticeship system.

\section{§ 2. OTHER TOWNS.}

Among the cities London does not stand alone in its conditions of boy labour. It may indeed be regarded as the most extreme example of urbanization, but it is nothing more ; it is a normal type, not an exception or monstrous exaggeration. As the capital of the Empire and the seat of government, it has its own characteristics, but so likewise has every other town. But dominating all these local variations and giving uniformity to the conditions of boy labour in our cities, remain the common features of the industrial development of to-day. This, at any rate, is the unanimous testimony of all those investigators-and they have been many-who have studied the problem.

I shall not, therefore, make any attempt to apply to other towns the detailed method of investigation $I$ have endeavoured to employ in the case of London. It will be enough to show that the general conditions are the same. What differences exist are differences of degree, and not differences of kind.

\section{(a) The Employment of School-Children.}

The investigations of the Interdepartmental Committee has proved beyond doubt that throughout the country it is common for children, while still attending school, to 
work long hours for wages. One or two quotations will be sufficient to justify this statement. The Report declares " that, as the door has been closed to their employment in factories and workshops and during school-hours, there has been a tendency, which many witnesses believe to be an increasing one, towards their employment in other occupations before morning school, between school-hours, in the evening, and on Saturdays and Sundays. Provided they make eight or ten attendances every week, they may be employed (with a few exceptions, and these little enforced) in the streets, in the fields, in shops, or at home, for the longest possible hours, and on the hardest and most irksome work, without any limit or regulation."1 Evidence abounded to show that such possibilities of overwork were frequently realized. Examples have already been quoted in the case of London, and it is unnecessary here to go over the same ground again.

That legislation, as at present enforced, has done little to cure the evil of overwork may be seen from the reports of school medical officers. Some of these are quoted in the Annual Report for I909 of the Chief Medical Officer of the Board of Education. The school medical officers were not asked to report specially on the problem, but their inspection of school-children revealed the magnitude of the evil.

"Several school medical officers report on the question of child labour duing I909. Dr. Thresh (school medical officer, Essex) places on record the serious extent to which children are employed out of school-hours in the

1 Report on Employment of School-Children, p. 5. 
Grays and Tilbury districts, and gives many individual examples. Dr. Forbes (school medical officer, Brighton) gives some interesting particulars from a statement prepared by the Inspector under the Employment of and Cruelty to Children Acts. In this area the head-teachers furnish regularly lists of children known by them to be employed out of school-hours. Among these children it was found that 39,25 , and 22 per cent. were illegally employed during 1907 , I908, and I909 respectively. Dr. Clarke (school medical officer, Walthamstow) found that I9 per cent. of the boys examined were employed out of school-hours, of whom I9 per cent. worked an average of eleven hours per week ; 32 per cent. worked ten hours and over on Saturdays ; 20 per cent. worked twenty hours or over during school-days. A full analysis of all children known to be employed out of school-hours at Yeovil is made by Dr. Page (school medical officer), who found that 22 per cent. of all children eight years of age and upwards were so employed, and of these 40 per cent. worked for twenty hours and upwards per week. Dr. Hope (school medical officer of Liverpool) produces evidence to show how usefully medical inspection may be linked up with the arrangements made to put into force by-laws relating to the employment of children. Thus, all cases where there was reason to suppose that the bylaws were being infringed were reported to the Sanitary Department. These children cases numbered 308 during the year, and a table is given showing in what manner they were dealt with. At Leamington, II9 boys and 30 
girls were reported by Dr. Burnet as employed in a wage-earning capacity either before or after school-hours, and 90 boys and II girls both before and after schoolhours. Of these, 63 children were of subnormal nutrition, 22 were suffering from anæmia, 2 from phthisis, 8 from heart disease, and 25 had enlarged tonsils. Several of these children were quite unfit for such employment, and the subject is deserving of a thorough investigation with a view to adopting protective measures where necessary. At Southport, I3I leaving boys (32\%7 per cent.) were found to be doing unskilled or casual work, and in Oldham I79 of the children inspected were similarly engaged." 1

As in London, so in other parts of the country, schoolchildren work for long hours, and no adequate means exist at present to prevent the evil. As in London, so in other parts of the country, signs of serious physical weakness are the common accompaniments of this employment, and the health of the rising generation is injured. As in London, so in other parts of the country, the forms of employment in which children are engaged are uneducational, and tend to lead children, when school-days are over, into the " blind-alley" occupations.

Besides these children, there are about 38,000 " halftimers." 2 It is needless here to dilate on the evils of the half-time system, which allows children who have

1 Report of Chief Medical Officer of Board of Education for I909, pp. 80-8I, note.

2 Report of Consultation Committee on Continuation Schools, p. 206. 
reached the age of twelve to spend half the day in the factory and workshop. It is condemned by all qualified to pass on it an impartial judgment. Its continuance reflects little credit on the humanity of those employers and those trade unions who have repeatedly opposed its abolition.

\section{(b) The Entry to a Trade.}

The survey of conditions of juvenile employment in London made clear certain facts. There was the growing demand for boys in what has been called " blind-alley" occupations, and the demoralizing effect of such work. There was the difficulty of obtaining adequate training for those who had entered a skilled trade. There was a general lack of supervision in the workshop. And, finally, there was no easy passage from youth to manhood. It is impossible to read the Report of the Poor Law Commission and the volumes of evidence, or to study the various investigations in to the conditions of sundry towns, without being convinced that London is in no way peculiar. The chief difficulty in approaching the problem lies in the selection of the all too numerous witnesses.

The Report of the Poor Law Commission probably provides the best summary of the mass of evidence on the subject. Both Reports-Majority and Minority-alike realize the gravity of the problem, not for London alone, but for the whole of the country. "The problem," says the Majority Report, " owes its rise in the main to the enormous growth of cities as distributive centres, giving innumerable openings for errand-boys, milk-boys, office and shop 
boys, bookstall-boys, van, lorry, and trace boys, streetsellers, etc. In nearly all these occupations the training received leads to nothing ; and the occupations themselves are, in most cases, destructive to healthy development, owing to long hours, long periods of standing, walking, or mere waiting, and, morally, are wholly demoralizing." 1 Or, again: "The almost universal experience is that in large towns boys, owing to carelessness or selfishness on the part of the parents, or their own want of knowledge and thought-for the parents very often have little voice in the matter-plunge haphazard, immediately on leaving school, into occupations in which there is no future, where they earn wages sufficiently high to make them independent of parental control and disinclined for the lower wages of apprenticeship, and whence, if they remain, they are extruded when they grow to manhood." 2 Or, to go to the Minority Report: "There are the rivet-boys in shipyards and boiler shops, the 'oil-cans' in the nut and bolt department, the 'boy-minders' of automatic machines, the 'drawers-off ' of sawmills, and the ' layers-on ' of printing works, and scores of other varieties of boys whose occupations presently come to an end." 3 Or, again : "In towns like Glasgow, Liverpool, Bristol, Newcastle, the proportions of van-boys, etc., are as large as in London." 4 Employers do not always conceal the fact: "In the words of a frank employer, they (the boys) are not taught; they

1 Majority Report of the Poor Law Commission, p. 325.

2 Ibid., p. 325 .

${ }^{3}$ Minority Report of the Poor Law Commission, p. Ir66.

4 Ibid., p. Ir66. 
are made to work continuously at their own little temporary trades." 1 If we desire actual figures of those engaged in one class of the "blind-alley " occupationsmessengers-Mr. Jackson tells us that " under fourteen years of age there are no less than $32,536\left(23^{\circ} 5\right.$ per cent. of those occupied under that age), while there are 4I,659 aged fourteen, and 54,592 from fifteen to nineteen years of age inclusive, of which it is probable that the bulk are under seventeen years of age." 2 Writing of Norwich, the same writer says : "There seems little doubt that the boy labour is used up for industrial purposes, and that they are left less capable members of the community, with little prospect of good work when they become adults." 3

Apart from the Report of the Poor Law Commission, individual writers of wide and varied experience outside London have voiced the same view. "It has never been so easy," writes Dr. Sadler, " as it is in England to-day, for a boy of thirteen or fourteen to find some kind of virtually unskilled work, involving long hours of deteriorating routine, in which there is little mental or moral discipline, but for which are offered wages that for the time seem high, and flatter his sense of being independent of school discipline and of home restraint." 4 And the same writer continues : "Certain forms of industry, which make large use of boys and girls who have recently left the elementary schools, are in part (except where the employers make special efforts to meet their responsi-

1 Minority Report on the Poor Law Commission, p. I 66.

2 Report on Boy Labour, p. 5. ${ }^{3}$ Ibid., p. 27.

4 M. E. Sadler, "Continuation Schools," Preface, p. xii. 
bility) parasitic in character, and get more than they ought, and more than their promoters realize that they are getting, of the physical and moral capital of the rising generation." 1

The Rev. Spencer J. Gibb, who has devoted special attention to the problem, writes: "The characteristic evils of boy work invade office work in a peculiarly subtle and dangerous form. In every city small offices are to be found in which the whole of the business, such as it is, is carried on by the master himself, who has frequently. to be absent from his one-roomed office. The office-boy, who constitutes the entire staff, is meanwhile left in charge. He has probably nothing to do, and spends his time either in vacancy, in mischievous expeditions along the corridor, or in reading trash of a bloodthirsty nature."2 Under such conditions supervision and control are negligible factors in the training of the workshop. It seems unnecessary to multiply examples; all persons of experience lament the increasing employment of boys in "blind-alley" occupations, and deplore the general lack of supervision.

The question of the skilled trades has received less attention, and there is much need of such a careful inquiry in various towns as had been made by Mr. Tawney in the case of Glasgow. Writing of the woodwork trades in that town, he says: "There is no regular training system; a boy learns incidentally, and is only shifted from one machine to another when the shop needs it. . . .

1 M. E. Sadler, "Continuation Schools," Preface, p. xiii.

2 The Rev. Spencer J. Gibb, " The Problem of Boy Work," p. 33. 
One of its employés was the best producer of wooden rings in his town, but could not make a wage at turning a table-leg," and adds that, " with the exception of a few old men who were trained under the apprenticeship system, the foremen are the only men with all-round skill." 1 While of the engineering trades he says: "On entering the works the lad who is going to be a fitter goes straight to the fitting shop and learns nothing else ; a lad who is going to be a turner goes to the machine shop and does not learn fitting." 2 Specialization is pushed even farther, and lads are kept to a single machine. Drilling, milling, slotting, punching, band-sawing, or screwing machines can be used after a few days' training, and this is all the experience a boy gets. And, speaking generally of Glasgow firms, Mr. Tawney says: "Boys are kept, as a rule, in their own departments. They are not taught ; they are made to work." These facts were obtained as the result of a careful inquiry among Ioo firms in Glasgow.

Glasgow, then, repeats the story of London; and there is good reason to believe that other towns, if submitted to a similar examination, would demonstrate the fact of the inadequacy of the workshop training of to-day. Apprenticeship, according to numerous witnesses, is everywhere decaying, and there is nothing except the technical school rising to take its place ; and under existing conditions the technical school can touch only a fringe of the problem.

1 Economic Journal, December, 1909, p. 522.

${ }^{2}$ Ibid., p. 522. 


\section{(c) The Passage to Manhood.}

The evidence of the last few pages, relating to the increase in the number of "blind-alley" occupations and to the inadequate training of the workshop, would show that, as in London, so likewise in other towns, there is no easy passage from the work of the youth to the work of the man. There is a break in the continuity of the service somewhere about the age of eighteen. New openings have then to be searched for, and new beginnings made, when the habits of learning have disappeared, even if the opportunities for it presented themselves.

It would seem superfluous to repeat for other towns the statistical evidence in support of this statement which was given in the case of London. "Blind-alley" occupations and troubled passage to manhood necessarily go together. Mr. Tawney's researches in Glasgow indicate clearly the difficulties of this transition period. A single quotation must suffice : "A district secretary of the Amalgamated Society of Engineers says of a worldfamous firm which employs several thousand men making a particular kind of domestic machine : ' It is a reception home for young bakers and grocers. Boys go to it from other occupations to do one small part of the machine. When they leave they are not competent engineers, and find it difficult to get work elsewhere."1 Detailed figures for the country as a whole in respect of certain trades may be found in Mr. Jackson's Report on Boy

1 Economic Journal, December, I909, p. 532. 
Labour. All evidence, from wheresoever collected, goes to show the existence of the break between the work of the boy and the work of the man.

It is trusted that sufficient evidence has been produced to prove conclusively that the conditions of boy labour in London do not differ essentially from the conditions of boy labour in other towns. The evidence could have been multiplied indefinitely and, what is most striking, among the mass of witnesses forthcoming there is none found to venture a contrary opinion. We may take it, then, as a well-established fact that in other towns besides London, supervision, training, and the provision of an opening are alike gravely and progressively defective. In other words, among the urban districts of the country no true apprenticeship system exists or is in course of creation.

\section{§ 3. RURAL DISTRICTS.}

No comprehensive inquiry has been made into the conditions of boy labour in rural districts and small towns. A few studies of individual villages exist-as, for example, " Life in an English Village," by Miss Maude Daviesbut these are not sufficiently numerous to justify any general conclusions. The return on Children Working for Wages, made to the House of Commons in I899, gives certain statistics. From the returns on pages $2 \mathrm{I}$ and 23 we see that for England and Wales some $5^{\circ} 2$ per cent. of children above Standard I. were working for wages. 
The percentage for boys alone would be 8.5 per cent., or for boys eleven years and upwards about I7 per cent., compared with 24 per cent. for London alone. These figures would seem to show that, while common, work among school-children over the country as a whole does not quite reach the London level. So far as can be gathered from the returns, it is in towns that the employment of school-children is most frequent, though in rural districts it is frequent enough to constitute a grave evil.

The same return gives the occupation of children as they leave school. On page $\mathrm{I}_{3} 3$ is the summary.

The table is incomplete: "In London the proportion of children is no less than 94 per cent. ; in the group of large urban districts, 72 per cent. ; while in the rest of England and Wales, including the rural districts and small towns, the percentage sinks to $47 . " 1$ Without a careful analysis, such as only local knowledge could supply, it would be dangerous to give much weight to the return. It does, however, appear from the summary that " blindalley" occupations bear a close relation to urbanization, and that the two increase together. Or looking at the question from another point of view, a boy in rural districts enjoys greater opportunities of continuity of employment in the passage from youth to manhood than he does in the towns.

There is good reason to believe that the prospects of

1 Elementary Schools (Children Working for Wages) Act, Part (2), Return for England and Wales, 1899, p. iv 
OCCUPATIONS OF BOYS ON LEAVING SCHOOL IN (I) LONDON, (2) LARGE URBAN AND MANLFACTURING DISTRICTS, AND (3) RURAL AND SMALL URBAN DISTRICTS OF ENGLAND AND WALES. ${ }^{1}$

\begin{tabular}{|c|c|c|c|c|c|c|}
\hline Occupation. & Londo & & $\begin{array}{l}\text { Large Urb } \\
\text { Manufact } \\
\text { Distric }\end{array}$ & & $\begin{array}{l}\text { Rura } \\
\text { Small } \\
\text { Distr }\end{array}$ & \\
\hline & No. & $\%$ & No. & $\%$ & No. & $\%$ \\
\hline Agriculture $\quad$. & IOI & - & 730 & 2 & I $7,95^{\circ}$ & 26 \\
\hline Building $\quad \ldots$ & 787 & 3 & $\mathrm{I}, 973$ & 4 & 3,744 & 5 \\
\hline Woodworking .. & 905 & 4 & $59 I$ & $\mathbf{I}$ & $66 \mathrm{I}$ & 1 \\
\hline Metal, engineering, and & & & & & & \\
\hline shipbuilding $\quad$.. & 949 & 4 & 4,090 & 8 & 3,119 & 4 \\
\hline Mining and quarrying & 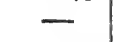 & - & $\mathrm{I}, 584$ & 3 & 6,5 I0 & 9 \\
\hline Textile .. & 49 & - & 6,046 & 13 & 5,522 & 8 \\
\hline Clothing & 665 & 3 & 1,634 & 3 & 1,612 & 2 \\
\hline Printing and allied trades & I,I I I & 4 & 868 & 2 & 680 & I \\
\hline Clerical .. & 2,060 & 8 & 5,666 & I 2 & 2,727 & 4 \\
\hline In shops $\quad \cdots \quad \ldots$ & $3,5^{84}$ & I 4 & 6,084 & 13 & 7,045 & Io \\
\hline 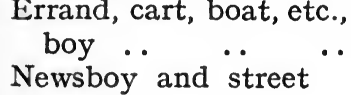 & 10,283 & 40 & I0,496 & 22 & 9,917 & $I_{4}$ \\
\hline vendor $\quad \ldots \quad \ldots$ & 964 & 4 & 1,472 & 3 & 1,223 & 2 \\
\hline Teaching & 120 & - & 430 & I & 557 & I \\
\hline Domestic service & 301 & I & I73 & - & 1,090 & 2 \\
\hline $\begin{array}{ccc}\text { Miscellaneous } & \text { and } & \text { in- } \\
\text { definite } & . . & \ldots\end{array}$ & 2,256 & 9 & $4, I 59$ & 9 & $4,8 \mathrm{I} 7$ & 7 \\
\hline cupied & 24,145 & 94 & 45,996 & 96 & 67,174 & 96 \\
\hline No reported occupation & 1,623 & 6 & 2,097 & 4 & 2,765 & 4 \\
\hline Grand total & 25,768 & 100 & 48,093 & 100 & 69,939 & 100 \\
\hline
\end{tabular}

1 Elementary Schools (Children Working for Wages) Act, Part (2), Return for England and Wales, 1899., p. vii. 
an all-round training are more favourable in a village than in a town. The fact, already mentioned, that immigrants from rural districts obtain the better positions in London trades, especially in the building trades, would seem to justify this conclusion. There is also the general consideration that rural districts are always nearly a century behind the industrial development of the towns, and represent therefore an older condition of affairs. Workshops are smaller, the gulf between man and employer less impassable, and the old paternal relation between boy and master more possible of attainment. We may therefore assume, without much risk of error, that training is better in rural districts than in towns.

On the other hand, while it is true that in industrial progress the villages lag behind the towns, they still follow them, though at an interval. Machine-made goods, especially in the woodwork trades, are in villages replacing the hand-made goods, and the demand for manual dexterity is to this extent decreasing. It would also seem to be true that the old indentured apprenticeship is falling into disuse. In the Wiltshire village of Corsley, for example, while apprenticeship occupied a prominent position in the past, in the story of to-day it passes almost without mention. In Miss Davies's ${ }^{1}$ study of the occupations of the inhabitants of that village, only one apprentice is mentioned. It is also a fact that those who are concerned with the administration of local charities

1 M. F. Davies, "Life in an English Village," chap, x. 
for apprenticeship are finding increasing difficulty in dis covering masters who are willing to take boys as inden. tured apprentices, even for a premium, and boys who are desirous of being indentured.

We may, perhaps, therefore assume that, while the conditions of boy labour are more favourable in rural districts than they are in towns, the old machinery of training is falling into disuse, and no adequate substitute is taking its place.

\section{V.}

The Break-up OF Apprenticeship.

The survey of the elements that make up the appren. ticeship of to-day is now complete. Each of the factors which contribute to the result-the State, Philanthropy, the Home, the Workshop-has been examined, and their influence appraised. It is therefore possible to pass judg. ment on the system, and, by realizing the present situation in all its relations, to understand clearly the nature and the extent of the problems which call for solution in the immediate future.

The period of apprenticeship has been shown to divide itself naturally into two parts. There are the years during which the boy is at school, ending somewhere about the age of fourteen. For the right use of these years we have seen that the State is beginning to accept full responsibility. Whether we have been concerned with the conduct, the physical welfare, or the training of the child, 
we have found collective enterprise assuming new duties, and carrying them out with a growing enthusiasm. Nor can we have remained blind to the large measure of success achieved. If defects here and there mar the result, they are clearly the defects that belong to all experiments in the early stages, and are obviously not the ineradicable faults of a worn-out system. In short, so far as regards the earlier years of the apprenticeship of today, there is no cause for despondency. Progress is the distinguishing characteristic of this first period; the boy is the centre of influences increasing in number, and deliberately planned to promote his well-being. One disquieting phenomenon that calls for attention is the large mass of school-children working long hours. Health is undermined, the effect of education impaired; while the occupations, essentially of the "blind-alley" type, encourage an unfortunate taste for this form of employment. Further, the various local authorities, especially in rural districts, have been very lax in using the powers conferred by the Employment of Children Act.

The second stage of apprenticeship covers the years between the ages of fourteen and eighteen. In our survey of this period we have been unable to find much cause for satisfaction. The State no longer recognizes its responsibility for the well-being of all its youth; it is content to offer opportunities of training to those who are able and willing to avail themselves of these advantages, and these last form only a small minority of the whole. The 
success of evening schools, technical institutes, and other places of higher education, so far as concerns those who come within that sphere of influence, only adds to our regret that that sphere of influence is so narrowly restricted. The majority, at least two-thirds, of the boys pass out of the control of the State, and for the completion of their apprenticeship we must look in other directions. Our search in these other directions has met with little reward; we have found everywhere failure, and, what is worse, failure that is rapidly progressive. Nowhere on a large scale can we discover provision made for the supervision and training of juveniles; from all sides we receive a tumult of complaint that things have gone astray. Philanthropic enterprise, whether represented by the religious bodies or lads' clubs, laments the lack of control over the boys, and frankly confesses its inability to deal satisfactorily with more than a small minority. The testimony of the home is the same; parents complain of the growing independence of their children, and to a large extent have ceased to attempt to exert any restraint over the conduct of their sons. Under the stress of modern industrial conditions and accentuated urbanization, the old patriarchal system of the family has broken down; the home represents an association of equals, in which, perhaps, the young can claim a predominant influence.

When we pass to the workshop, in the hope of reaching law and order and constructive thought, it is only to be confronted with the most signal example of an organiza- 
tion which defies every principle of a true apprenticeship system. That the boy of to-day is the workman of to-morrow is a thought that suggests itself to only a few of the most enlightened employers. To the many he is merely a cheap instrument of production to be used up, and then scrapped as waste machinery. $\mathrm{He}$ is kept at " his own little temporary task" ; and, to make things worse, he is in so much demand that discipline cannot keep him very steadily even to this, or his services will be withdrawn. With the separation of man's work from boy's work there is no easy passage from youth to manhood. With the minute subdivision of operations, there is small chance of a lad in a skilled trade becoming a master of his craft.

Apart from the small amount of medical inspection required by the Factory and Workshop Act, no attempt is made to insure that the growing lad is physically fit for the work in which he is engaged. His health is the concern of no one till its breakdown brings him under the Poor Law or thrusts him into the ranks of the unemployable. Undisciplined, with health and training neglected, the lad of eighteen tends to find himself more and more left without prospects, and a person for whom no one in particular has any particular use. In short, our survey of the problem of the apprenticeship of to-day shows conclusively that we have, in the true sense of the word, no apprenticeship system. The old apprenticeship system has broken up, and there is nothing come to take its place. 
It would be incredible if serious consequences did not accompany this complete break-up of the apprenticeship system; and it needs but little search to discover evils of farreaching significance. There is first the evil of an uncontrolled youth. A child at the age of fourteen is not fitted to enjoy the independence of an adult. This statement is a truism, but there is tragedy in the fact that society of to-day confers, as we have seen, this irresponsible freedom, in a more or less unqualified form, on the majority of boys when they leave the elementary schools. In the hooligan of the streets or in the youthful criminal we have the most striking example of the fruits of an undisciplined boy. The report of the Commissioners of Prisons for the year ending March 3I, I908, makes this clear. Writing of the Borstal Association, they say: "In this admirable report" (the report, that is, of the Borstal Association), " which should be studied by all who are interested in the causes of crime, after specifying many circumstances which induce the criminal habit, they refer in particular to the absence of any system of control or organization for the employment of the young, as one of the principal causes of wrong-doing. "When a boy leaves school the hands of organization and compulsion are lifted from his shoulders. If he is the son of very poor parents, his father has no influence, nor, indeed, a spare hour, to find work for him; he must find it for himself; generally he does find a job, and if it does not land him into a dead alley at eighteen he is fortunate, or he drifts, and the tidy scholar becomes a ragged and defiant corner loafer. Over 80 
per cent. of our charges admit that they were not at work when they got into trouble." '1 The Poor Law Commission calls attention to the evil effects of certain forms of employment which the boys choose because of the freedom they give. " ' Street-selling, for example,' says the Chief Constable of Sheffield, ' makes the boys thieves.' ' News-boys and street-sellers,' says Mr. Cyril Jackson, ' are practically all gamblers.' ' Of I,454 youths between fourteen and twenty-one charged in Glasgow during I906 with theft and other offences inferring dishonesty, I,208, or 83.7 per cent., came from the class of messengers, street-traders, etc.,' says Mr. Tawney."'2 And it would be easy to multiply indefinitely examples of this kind. It must not, of course, be assumed that all boys become hooligans or criminals, but all do suffer from the want of control and the need of a more disciplined life. Hooliganism is merely an extreme type of a disease which in a milder form fastens upon the boys who are allowed unrestrained liberty. The disease is the disease of restlessness - the restlessness of the town, the dislike of regularity, the joy in change for change's sake, and the habit of roving from place to place.

This disease, with the lack of proper technical training, leads on to unemployment when the age of manhood is reached. Unemployment is not the fate of the old only ; it is becoming common among the young. "The per-

1 Report of the Commissioners of Prisons for the year ending March 3I, 1908, p. I4.

2 Report of the Poor Law Commission, p. 325. 
centage of men under thirty years of age qualified for assistance under the Unemployed Workmen Act, I905, was :1

\begin{tabular}{|c|c|c|}
\hline & Up to March 31, 1906. & $\begin{array}{l}\text { Twelve Months ending } \\
\text { March } 3^{x}, \text { x907. }\end{array}$ \\
\hline $\begin{array}{l}\text { London } \ldots \\
\text { Whole of England }\end{array}$ & $\begin{array}{l}23 \cdot 9 \\
27 \cdot 3\end{array}$ & $\begin{array}{l}27.4, \\
30 \cdot 2 "\end{array}$ \\
\hline
\end{tabular}

“ It has become clear," says a manager of boys' clubs with a very wide experience, " to all students of the labour problem that a wrong choice of their first work-or, rather, no choice at all, but a drift into it-is responsible for the presence of considerable numbers of young men amongst the unemployed." 2 The Reports of the Poor Law Commission, Majority and Minority alike, repeatedly voice the same opinion. "The great prominence given to boy labour, not only in our evidence, but in the various reports of our special investigators, leads us to the opinion that this is perhaps the most serious of the phenomena which we have encountered in our study of unemployment. The difficulty of getting boys absorbed, through gradual and systematic training, in the skilled trades is great enough; but when to this are added the temptations, outside the organized industries, to enter at an early age in to occupations which are not themselves skilled and give no opportunity for acquiring skill, it seems clear that we are faced by a far greater problem than that of finding employment for

1 Morning Post, January 3, 1909, letter from Professor M. E. Sadler.

${ }^{2}$ Russell and Rigby, “ Working Lads' Club,” p. 286. 
adults who have fallen behind in the race for efficiencynamely, that the growth of large cities has brought with it an enormous increase in occupations that are making directly for unemployment in the future." 1 The Minority Report is equally emphatic. "There is no subject," it says, " as to which we have received so much and such conclusive evidence as upon the extent to which thousands of boys, from lack of any sort of training for industrial occupations, grow up, almost inevitably, so as to become chronically unemployed or under-employed, and presently to recruit the ranks of the unemployable. In Glasgow nearly 20 per cent. of the labourers in distress are under twenty-five, and one-half of them are under thirty-five."2 Or again: "It has been demonstrated beyond dispute that one of the features of the manner in which we have chosen to let the nation's industry be organized is that an increasing number of boys are employed in occupations which are either uneducative (in the sense of producing no increase of efficiency and intelligence) or unpromising (in the sense of leading to no permanent occupation during adult life) ; secondly, that there is a constant tendency for certain industrial functions to be transferred from men to boys, especially when changes in the processes of manufacture or in the organization of industry are taking place rapidly. The resulting difficulty is the double one of the over-employment of boys and the under-employment of men."3

1 Majority Report of the Poor Law Commission, p. 326.

2 Minority Report of the Poor Law Commission, p. 1165.

3 Ibid., p. 1166. 
It is hoped that the present chapter may have made clear the various steps in this unfortunate process of industrial development. First, we have the qualities which are the result of the school training-qualities of regularity, obedience, and intelligence-qualities required, indeed, in all forms of work, but supplying a complete technical outfit alone for the "blind-alley" occupations. The boys leave school, having had expended on them in each case a capital sum of public money of about one hundred pounds. They are valuable assets, and employers have discovered the fact, and adjusted their methods of production or distribution to make full use of this new and valuable supply. High wages attract the boy, who makes his own choice, and earning is regarded as more attractive than the laborious and less remunerative learning.

This leads on to the second stage, the "blind-alley" occupation or the skilled trade where there is no real training. Four years of this kind of work dissipate the effects of elementary education. Too often weakened physically by long hours of employment, demoralized by the life of freedom and the fatal facility in obtaining a second job when fancy has made him throw up the first, robbed by disuse of the power to learn even if the inclination were present, he is, at the age of eighteen, a distinctly less valuable asset in the labour market than he was four years before. The hundred pounds investment of public money intended for life has been squandered in youth; the employer has possessed himself of it; and when the boy 
asks the wages of a man, he is informed that his services are no longer wanted, and told to transfer them elsewhere.

Then comes the final stage of degeneration-unemployment or under-employment. The habit, acquired through four years of constant practice, of throwing up a job on the smallest pretext, remains with the lad of eighteen, but the facility of finding another is no longer his. The intensity of the demand for men varies almost inversely with the intensity of the demand for boys; the two are competitors in the same labour market, and of the two the boy is the cheaper and the more efficient instrument of production. Further, habits of boyhood have too often bred a liking for casual employment, with its frequent holidays. Here, also, the employers are willing to oblige him ; they find it convenient to have at their beck and call a reserve of labour which can be drawn upon when business is brisk, and discharged in times of slackness. Finally, if he desires regular employment, it is none too easy to discover a suitable opening. The sphere of his usefulness is small; he has for sale a certain amount of animal strength, none too well developed, but has little else to offer. He can push and he can pull indifferently well, but in the world of industry there is not, as is supposed sometimes, an unlimited demand for pulling and pushing. And all the time he is faced with the fact that recruits to the army of pushing and pulling are coming from all sides. Men skilled in the performance of a single operation, and robbed of their well-paid employment by a new invention; men from decaying trades 
and incapable through lack of training of adapting themselves to fresh conditions ; men a little past the vigour of manhood; men discharged for misconduct; men who have lost their work through the bankruptcy of a company or the death of a master-all alike, when everything fails them, turn in desperation to pulling and pushing ; and meanwhile machines of novel design decrease year by year the demand for pulling and pushing.

All these effects, with innumerable variations, are the result of a wrong start, and of the neglect during the years that lie between the ages of fourteen and eighteen. Want of supervision, want of technical training, want of an opening for which special preparation has been giventhese are the three great and characteristic evils of the present industrial situation. Taken together, they are a negation of all apprenticeship in the true sense of the word. During the course of the last few years we have at least learned to know the cause of our suffering, and to know the cause is at least the first step in the path of prevention. And, further, we have begun to see rising from the ruins of the old stabilities of life and the ancient order of industrial organization an edifice-small, indeed, at the moment, but bearing the mark of constructive thought, because reared by the growing power of collective enterprise ; and, knowing this, we can turn in a spirit of hope to the task of creating a new apprenticeship system. 


\section{CHAPTER VI}

\section{THE NEW APPRENTICESHIP}

In the present chapter we must endeavour to find some remedy for the evils disclosed in the preceding pages. The old apprenticeship system has broken up, and there is nothing come to take its place. In consequence, the youth of the country is to a large and growing extent passing through the years of adolescence without supervision, without technical training, without prospects of an opening when manhood is reached. These are defects in the industrial organization so obvious that they are now attracting general attention, so grave that there is need of immediate and comprehensive measures of reform.

In what direction is the remedy to be looked for ? From what quarter may we expect the new apprenticeship to come? The survey of the conditions of boy labour, contained in an earlier portion of this volume, has disclosed two forces at work in the training of the youth of the country. The one force is destructive in its action; the other constructive. Reform obviously lies in the repression of the former and in the encouragement of the latter; there is no other alternative.

The force of destruction has been found throughout 
associated with the characteristic phenomena of the industrial revolution. The accentuated spirit of competition, the increasing use of capital and machinery, with the consequential development of large undertakings, and the rapid changes in methods of production to meet new demands or to make use of new inventions, have all alike been hostile to the well-being of the boy. The system, created by what may be called the natural growth of modern business organization, has been a system which has, in one form or another, continually attempted to exploit child labour. Under this system children, in days gone by, were driven to the mine and to the factory, or herded in gangs in the fields and barns of the farm, and even at the present time are allowed to perform tasks far beyond their strength. Under this system we have watched the slow and continuous decay of indentured apprenticeship, the steady decrease of facilities for obtaining an all-round training in the workshop, and the ever-broadening gulf separating youth from manhood in the sphere of industry. As a result of this system we have seen the hand of control lifted from the shoulder of youth, and have noted lads, under the wayward guidance of an irresponsible freedom, drifting into the path of crime and disorder. We are driven to believe that it is the young who swell the armies of unemployment, and have realized with sudden dismay that, young though they are, they are yet too old to break the set habits of an unfortunate past. And we are beginning to perceive clearly that these phenomena, of ill omen, are not a mere accident, 
but an integral part of the industrial organization; and to understand that, in spite of numerous superficial changes, the system, born of the revolution of a hundred years ago, has not altered in essentials, and now, as then, threatens with destruction the youth of the land.

That system has never enjoyed full freedom of development, but the limits set on its power for evil have not come from within; they have come from without, and been imposed on the employers by the legislative action of the State. It is the State which has throughout the period supplied the second or regulative and constructive force in the training of the youth of the country. It has forbidden the employment of boys in some occupations, and in others limited the hours of employment. Acting without any clearly defined plan, but striking at the evils, which gusts of popular opinion denounced and refused to tolerate, it has yet made impossible the worst abuses of child labour. It has, however, long since passed beyond the realm of mere veto, and has these many years entered the sphere of constructive reform. The scheme of compulsory education, the provision of opportunities for technical instruction, and the powers, recently conferred on local education authorities, to attend to the physical condition of school-children, are all signal examples of the beneficent influence of the second force.

We are left, then, with these two forces-the force of destruction and the force of construction; and the fate of the youth turns on the issue of the struggle between the two. They are not, indeed, the only forces concerned 
in the problem of boy labour, but, compared with their influence, all others sink into insignificance. The State and the industrial system both possess the characteristic of universality, and no other organization can make the same claim. Philanthropic and religious associations have always been found to protest against the abuses of child labour, but their protest only became generally effective when the State gave to it the force of law. Philanthropic and religious associations have been pioneers in the field of education, but the advantages were offered to all only when the State stepped in and assumed the responsibility. Individual employers have always been found to offer to their lads humane conditions of work and full opportunities of training, but these remained the privileges of a few, and it was only through State interference that the many obtained their share. As pointing the way to reform, these other agencies have been, and are, of priceless value to the community, but as themselves the instrument they have invariably proved a failure. We are left, then, with two forces which alone need to be taken into account-the industrial organization and the State. For the creation of the new apprenticeship system either the industrial organization must reform itself, or the State must reform the industrial organization : there is no third alternative.

Let us begin with the first alternative, and ask ourselves whether there is any reasonable hope of reform from within the industrial organization. The experience of the past is uniformly hostile to any such expectation. 
In the history of the last hundred years there is no single exception to the rule that all general improvements in the conditions of boy labour have come from without, and not been carried out from within. The experience of the present repeats in an even more emphatic way the experience of the past. It is impossible to point to one single example of an industrial reform now in course of development, and affecting on a large and beneficent scale the prospects or the training of the boy. It would be easy to cite a hundred instances of the contrary process. The whole of the last chapter is nothing but a detailed summary of the progressive defects of the industrial system, and its attempts to exploit in its own interests the value of boy labour. We saw how, by the multiplication of "blind-alley" occupations, the industrial system contrived to lay hold on and use up most of the products of an improved elementary education initiated by the State. Past and present experience are in accord; we cannot look for reform from within.

It is necessary to guard against a possible misinterpretation. There is no thought here of blaming the employer. The fight lies not between boy and employer, but between the force of the State and the force of competition, using the last word to denote the most marked characteristic of the industrial revolution. The employer is in general as much a victim of the process as the boy. He cannot be justly blamed for what he cannot be fairly expected to prevent. The exigencies of competition drive him to select the cheapest methods of production at the 
moment. If these methods involve the exploitation of the boy, it is unfortunate for the boy, but the employer has no other alternative. To produce as cheaply as his neighbours is the one condition of success ; more remote considerations cannot enter into a business undertaking. Those well-intentioned persons, with a smattering of illdigested science and a system of economics far removed from all practical realities, who talk amiably of the interests of employers and their boys, as future workmen, being identical, confuse the good of the present generation with the good of the generation that comes after. It is undoubtedly a fact that any system which injures the workers will in the long-run injure the trade of the country, but this is true only in the long-run, and the run is often very long. Now, survival in business is determined in the immediate future. The heavy charges on fixed capital, the interest on outstanding loans, the weekly wages bill, and the long tale of daily outgoings, make it impossible for the employer to follow proper methods of training in the hope that the new generation of workers will, by their added efficiency, recoup him for his expenditure. To last till that time he must live through the interval, must obtain that contract to-day, this order to-morrow, and must get it at a profit-in other words, he must choose the cheapest method of production here and now; there and next year will be too late. It will be no inducement to him to reflect that his methods would in the long-run prove the best, if he knows that he cannot stay the course. Competition is 
of to-day; it takes no account of the happenings of tomorrow. Those who in the struggle cannot survive this year will not live to reap the harvest of future years. Agreement among employers on such questions has been found impossible; the temptation to win by evasion an illicit success proves too strong for the majority. Those who pursue the better methods disappear; those who pursue the worse survive to propagate their kind. There is valid in the world of business a law somewhat analogous to Gresham's law in matters of currency; the bad pushes out and replaces the good. There is a real struggle between the interests of one generation and the next. The employer must concern himself with the things of his own day; it is for the State, whose life is ageless, to guard the welfare of those who are to come. By insisting on the methods that are good in the long-run, by forbidding those which are good only in the immediate present, it places all employers on the same level, and enables the best of them to do what was before impossible. It does not thereby interfere with competition ; it merely changes the direction of competition by guiding it into less injurious channels. But the secret of success, as demonstrated by the experience of more than a century, must be sought in the enactment of general regulations, which will apply to all employers, and not be looked for in what is sometimes termed the spirit of growing enlightenment. Unless it can be shown that the immediate interest of the employer is one with the proposed reform, nothing really effective can be done by moral suasion; 
while, if the two are in accord, moral suasion is superfluous. It can hardly be supposed that the contemplative outsider should know the business of the employers better than they do themselves. The mere fact of calling to our aid the power of moral suasion should be enough to show that enlightened self-interest will not suffice; we do not appeal to a man's conscience when we can appeal to his pocket. If, then, reform and the immediate interest are not in accord, consent on the part of one employer means risk of failure in a world where salvation depends on very small margins of profit.

It is, therefore, for the most part labour lost to devote time to the consideration of reforms which do not rest on the basis of legal obligation, and we might at once turn to considerations of State control and State enterprise if it were not for the fact that in the minds of many there still remains a hope of the coming of salvation from another direction. They advocate the revival of the old indentured apprenticeship system, and believe that they have only to explain the situation adequately to the employer for him to realize that his interests lie in its revival. This belief assumes, as already mentioned, that the outsider knows the business of the employer better than he does himself-a tolerably large assumption. We might drop the matter with this criticism, but a reexamination of the old apprenticeship system, in the light of the industrial revolution and of the proposals for its revival, will help us on our journey towards the goal of the new apprenticeship. Such examination will 
show, first, the conditions which a true apprenticeship must fulfil; and, secondly, that those who hark back upon the past for their ideals of reform are conscious that the past must change its dress before it can hope to commend itself to the critical taste of the present.

Now, in its best form, as was shown in the second chapter of this book, the old apprenticeship system was a success. It did afford means of adequate supervision over the youth of the country; it did supply them with technical training; and it did provide an opening in an occupation for which special preparation had been made. But a closer examination of the problem showed that success depended on the satisfaction of three conditions : First, it was essential for the apprentice to live with his master, or at any rate that the relations between the two should be of a paternal character; the second essential was the universality of the small workshop, with the facilities it gave for an all-round training; and, thirdly, an essential part of the system was the existence of the gild, which represented masters and men alike, and in the interests of all inspected and controlled the methods of the workshop. With the dissolution of the gilds we saw the first weakening of the apprenticeship system. There was now no authority guarding the interests of the trade as a whole; compulsory apprenticeship was often used as a means of supplying the employer with cheap and enforced labour, for whose future he had no responsibility. With the advent of the industrial revolu- 
tion we watched the steady disappearance of the small workshop. Training became difficult, and often impossible. With both masters and men formal apprenticeship lost favour, and the system entered on its second stage of decay. With the multiplication of "blind-alley" occupations, with the growing cleavage between man's work and boy's work, and with division of labour pushed to its utmost extreme, came, as has been proved, the break-up of the apprenticeship system.

Now, there is nothing in the signs of the times to herald the approach of a new industrial revolution and a return to the old order of the Middle Ages. Machines and machine methods have come to stay, and must stay if the varied needs of the huge populations of to-day are to be satisfied. The more serious advocates of the revival of indentured apprenticeship admit this fact, and fully realize that modifications of the system are necessary. They suggest that committees of volunteers should assume certain of the functions of the gild; they should exercise a kindly supervision over the boy in his home, and take steps to insure that the conditions of the indenture are observed by the employer. Secondly, they propose that the one-sided training of the workshop should be supplemented by technical classes provided by the education authority and supervised by an advisory committee of representatives of the trade. Finally, they urge that these proposals, so far from being visionary, have actually been realized in practice with complete success. 
Why may not we look for a general extension of these methods ?

The answer is tolerably obvious. The experiments have undoubtedly been successful. They have shown the steadying influence exerted over the boy by an indenture; they have shown the advantages that come from friendly visiting at the home or the workshop ; they have shown the value of technical classes and trade schools supervised by representatives of the trade. But what they have not shown is that the experiment, while resting on a purely voluntary basis, admits of indefinite expan. sion. Indeed, the fact that the co-operation of the education authority is invoked, in order to provide technical instruction that shall supplement the training of the workshop, is sufficient evidence that we cannot dispense altogether with the assistance of the State. But much more remains to be said against the possibility of indefinite extension. Take the case of indentures. $I t_{\text {, }}$ is true that some employers can be found willing to receive indentured apprentices, and some boys willing to be indentured. But this does not affect the general rule that the conditions of the modern workshop do not allow of the use of apprentices, whose training is enforceable at law, or discount what is a matter of common observation-that neither employers nor boys like to bind themselves together for a period of years. Indentures may be an excellent plan for curbing the independence of the boy, but it does not, unfortunately, follow that the boys who most want curbing will be the boys 
who will accept this fretting restraint. What happens in practice is that a select number of boys willing to submit to control are brought into relations with a select number of employers willing to be troubled with boys. This is good as far as it goes, but it goes no way in the direction of providing supervision for the boys who most need it. Or take again the question of supplementing in the technical institute the training of the workshop. Experience here and in other countries shows conclusively that technical instruction, to be really effective, must be given during the daytime, when the lad is fresh, and not during the evening, when he is wearied out by the day's work. But, ignoring the necessarily limited number of cases in which boys are able to forgo earning altogether, instruction during the day is possible only where employers allow their apprentices time off during the day to attend classes. It is true that some few employers have given this permission, but their number is strictly limited. In the hope of extending the principle, the London County Council recently carried out an elaborate inquiry among employers, but with very small results. "If we compare," says the report, " the magnitude of the elaborate inquiry carried out by the principals of polytechnics and technical institutes, by the skilled employment committees, and by the Council itself, with the extent of the success attained, we are bound to admit that the results are of the most meagre dimensions. There appears no prospect of inducing employers on any large scale to co-operate with us in the establishment of a satisfactory 
system of 'part-time' classes." 1 Extension on a large scale and on a voluntary basis is impossible.

But, neglecting the question of possibilities, is the revival of an indentured apprenticeship, as a method of learning certain trades, in itself a thing to be desired ? There remains one difficulty that has never satisfactorily been surmounted. If indentured apprenticeship is the door leading to a skilled trade, there will be a movement in the trade to close all other doors. Those who have paid a premium, or at any rate served their time for low wages, cannot be expected to allow without complaint vacancies in the trade to be filled by men who have not passed through a similar period of servitude. If the door is closed, there is no way of recruiting the trade in times of expanding business. But, in general, prohibition has not proved practical, and other ways of entry are discovered, and as these ways are easier, it is only natural that people should tend to choose the easier path. Indentured apprenticeship has never escaped from this dilemma; either the trade is closed to strangers when there is no means of expansion, or the trade is open when there is no inducement to be apprenticed. The change in modern industry, with its tendency to break down the barriers between trade and trade, only accentuates the acuteness of the dilemma.

Finally, assuming indentured apprenticeship to be both practical and desirable, would it provide a solution for

1 Minutes of the Education Committee, February 24, 1909, p. 422 . 
the problem of boy labour? It is obvious that it would only touch a fringe of the question. We have already seen that some two-thirds of the children, as they leave the elementary school, enter a form of occupation which leads only to unskilled labour, and even for that provides no adequate training. An apprenticeship system would not affect these two-thirds. A boy cannot be apprenticed as an errand-boy, or in one of those workshops where practically only boys are engaged. Not only is this class the most important in respect of numbers; it is also the class most urgently in need of control. It is here that degeneration and demoralization are most marked, while it is here that indentured apprenticeship offers not even a shadow of a remedy. A system which ignores the majority, even if it provided for the favoured few, cannot be regarded as affording a possible solution of the problem of boy labour.

We cannot, therefore, look to the revival of apprenticeship, even when supplemented by technical training, to carry us far on the road of reform. It would, however, be a mistake to under-rate the lessons of the experiments. They have shown the value of indentures as a means of controlling the boy; they have shown the value of sympathetic supervision; and they have shown the value of the technical school in widening the inadequate training of the workshop. The defects of the experiment lay in the necessary limitations of the case. Remove the limitations, and you remove the defects. We want universal indentures, universal supervision, universal 
training. To guard against the dangers of creating a privileged class through the establishment of an apprenticeship system we must see to it that all alike serve a period of apprenticeship. Obviously, we cannot apprentice all boys to employers ; we must, therefore, apprentice all boys to the State. There is nothing new in this proposal. Already, through the law of compulsory attendance at school, all boys are so apprenticed between the ages of five and fourteen. What is necessary is an extension of the period of an already existing apprenticeship system.

In the search of a means of preventing an evil, the most difficult task is always to exclude the inadequate and the irrelevant. When all paths of advance, with one exception, have been blocked, there is no longer any choice or risk of losing one's way. We have now seen that all ways, except the way of collective control and collective enterprise, fail to reach the desired goal, and, having exhausted all other alternatives, must fall back upon the State. Some do this willingly, some reluctantly, but all, with a few exceptions that may be disregarded, appeal to the State when they are convinced that help can be looked for from no other source. We are now in that position, and must frankly face the situation.

Failing assistance in any other direction, we must call on the State to organize a new apprenticeship system. Such a system must make due provision for supervision, training, and an opening. It remains to be considered how these three essentials can be secured. 


\section{I}

\section{SUPERVISION.}

A boy must be under some sort of supervision until he reaches at least the age of eighteen. Such supervision must have respect to his physical well-being as well as to his conduct. Neither the home, nor philanthropy, nor the workshop can be looked for to provide this supervision. They have all failed, and that failure is progressive. The State remains as our only hope. The State has not failed; it has made impossible the worst abuses of child labour, and through its educational system has been an influence for good in the moral and physical development of the children. Its success has been great, and that success has been progressive. Where it has failed, it has failed because its supervision has been withdrawn too soon. The remedy is obvious : we must extend the sphere of State supervision. Three reforms are urgently necessary: (I) The raising of the age of compulsory attendance to fifteen ; (2) the complete prohibition of the employment of school-children for wages ; and (3) the compulsory attendance of lads between the ages of fifteen and eighteen at some place of education for at least half the working day. With regard to these proposals, it may be said that all three are supported by the Minority Report of the Poor Law Commission and by the labour organizations which have in general expressed their 
approval of that Report. (I) and (3) are the recommendations of the Report of the Education Committee of the London County Council, adopted unanimously by that body in February, I909; while (I) and (3) also received a qualified approval from the Majority Report of the Poor Law Commission, and from the Report of the Consultative Committee of the Board of Education on Continuation Schools. They have, therefore, behind them a strong backing of expert opinion.

\section{(a) The Raising of the School Age.}

More than ten years have elapsed since Parliament last raised the age of compulsory attendance. There is almost universal agreement that the time has come for adding another year. The discipline of the school is successful while it lasts, but fails in permanent effect because it is withdrawn too soon. In the last chapter we saw from the study of the census tables that for at least the first year after school the boys have settled down to no very fixed employment. Many of the skilled trades do not take learners and apprentices before the age of fifteen. " It is clear," say the Education Committee of the London County Council, " that the year after leaving school-the year, that is, between the ages of fourteen and fifteenis for the children concerned a year of uncertainty. Nearly half are returned as without specified occupation. No doubt a large proportion of the number are attending some place of education, but it is no less true that a considerable number are not classified, because for the time 
being they are doing nothing. They have thrown up one situation and are looking out for another. In this respect we must remember that it is a common practice-at any rate, so far as the poorer section of the community is concerned-for the children, and not their parents, to select for themselves the form of occupation and find for themselves situations. The children are too young to choose wisely, and, as a natural consequence, shift from place to place until they discover something that suits their taste or ability. It would be difficult to imagine a more unsatisfactory method of training. Till the age of fourteen they are carefully looked after in school; at the age of fourteen they are set free from all forms of discipline, and become practically their own masters. We must not, therefore, be surprised that under such conditions the effect of the school training is transient, and the large amount of money spent on their education to a great extent wasted." 1 And, summing up the whole case for the raising of the school age, the Education Committee say: "The advantages of keeping children at school until the age of fifteen are many and obvious. They receive an extra year's instruction at a time when they are most apt to learn; they are kept for another year under discipline just at the period when it is easiest to influence permanently the development of character. With the exterision they escape the year of aimless drifting from occupation to occupation, and, when called on to choose a profession, they will

${ }^{1}$ Minutes of the Education Committee, February 24, 1909, p. $4^{16}$. 
have a year's extra experience to help them in the choice. We may hope that under these new conditions the tendency to follow the line of greatest initial wages will decrease, and be replaced by a tendency to consider as of paramount importance prospects of training and hope of future advancement." 1

In raising the school age we should take the opportunity of getting rid of certain anomalies which now exist. While for the vast majority of children in London and many other places attendance is compulsory up to the age of fourteen, exemption is possible at the age of twelve and thirteen for a small minority. In certain parts of the country large numbers of children are allowed to leave before the age of fourteen. It is unfortunate that it is the cleverest children who are entitled to this earlier exemption. We are here looking at the problem of apprenticeship from the standpoint of supervision, and in the case of supervision age and not mental attainment must be the determining principle. The bright precocious boy of twelve or thirteen is precisely the boy who stands most in need of control. Morally and physically he is likely to suffer from the effects of premature freedom. The sleepy dullard, who is kept at school until fourteen, could be freed from discipline at an earlier age, with less risk of serious harm. In raising, then, the age of compulsory attendance to fifteen, we must abolish the privileges of exemption

1 Minutes of the Education Committee, February 24, 1909, p. 4 I6. 
and the powers of local option, and enact that all children shall attend school full time until they reach the age of fifteen.

\section{(b) The Prohibition of Child Labour.}

Much space has in this volume been devoted to the task of demonstrating the extent and the evils of child labour. It has been shown that anything except the very lightest employment is physically injurious. It has been made clear that the work in which children are engaged is frequently demoralizing, while it never paves the way to entering a skilled trade when school is left. They are essentially "blind-alley" occupations. Further, we have seen good reason to believe that the habit of earning money and the precocious sense of independence so encouraged are not in the best interests of order and discipline. We note the evil in its worst form under the " half-time" system. "The half-timers," we are told, " become clever at repartee and in the use of "mannish" phrases, which sound clever when they dare use them. They lose their childish habits ... some of the boys commence to smoke and to use bad language." 1 Finally, it has been proved that limitation of the hours of employment in the case of school-children is in practice impossible; there is no ready way of detecting breaches of the law. We are, therefore, driven to the conclusion that, unless the evils are to remain-and this is not tolerable - we must prohibit altogether the employ-

1 M. E. Sadler, "Continuation Schools," p. 334. 
ment for wages of children liable to attend school full time.

Various objections are made to the proposal. We are told by many of the witnesses who appeared before the Interdepartmental Committee on Wage-earning Children that a little light work was good for boys ; it kept them out of mischief. Ignoring the difficulties of insuring that the work shall be little and light, they do not seem to make out their case. In London, as has been shown, not more than a quarter of the boys during the course of their school time are ever engaged seriously in paid employment. If, therefore, the work was beneficial, we should expect to find in the after-career of the 25 per cent. evidence of the advantages they have enjoyed, and in the case of the 75 per cent. signs of failure due to their less fortunate training. But all experience points in the opposite direction. It is the 25 per cent. who drift most generally in to the "blind-alley" occupations; it is from this 25 per cent. that the majority of hooligans and youthful criminals are recruited.

It is also argued that there are certain tasks which only children can perform, because they occupy only a small portion of the day. Papers must be delivered and milk left at people's houses. But in Germany much of this work is done by old men, ${ }^{1}$ and even in this country the " knocker-up" in the morning is not a child, but an old

1 " Berlin, though growing luxurious, is not yet as spendthrift of young life as is London. The newspaper-boy and the streettrader are unknown" (Report to the London County Council, by Miss Durham, p. 3). 
man. Employers in the textile trades declared that it is only by beginning young that children can acquire the necessary quickness and deftness of touch. But as these trades absorb in the adult service only a small proportion of the children engaged, and seeing that in many instances the half-time system has been dropped as uneconomic, there does not seem much force in this objection. Moreover, it cannot be beyond the power of manual training in the schools to provide a fitting and less injurious substitute.

The arguments in favour of the continued employment of school-children are the arguments of the old world, and the new world is becoming a little tired of the arguments of these old-world people. The time has come to make a stand, and insist that for all children there shall be insured the blessings of childhood. The first step in this direction lies in making it impossible for them to enter the ranks of the wage-earners as long as their names remain on the roll of the elementary school.

\section{(c) The New Half-Time System.}

The proposals for raising the school age and for prohibiting child labour during that period will do much to strengthen the system of supervision. Another year of school discipline; another year of medical inspection and medical treatment; protection during another year from the evil effects of overwork and from the demoralization due to "blind-alley" occupations and premature earningthese reforms will bring us some way on our journey 
towards the new apprenticeship, but they will not bring us the whole way. There remain the three years which lie between the ages of fifteen and eighteen, and include the greater part of the period of adolescence-in some respects the most important period in the development of a human being. It is during these years that character begins to take its permanent set; it is during these years that, with the coming of puberty, there is most risk of ugly and dangerous outbreaks; it is during these years that physical health demands the most careful attention ; and it is during these years that, with the exception of the failures of civilization-the physically, the mentally, and the morally defective-there is no real supervision or, under existing conditions, any hope of securing it.

To allow irresponsible freedom during these years is to court disaster ; to give it suddenly and in an unqualified degree, as it is given now when the school career is brought to an abrupt end, is to follow a course condemned by all educationalists. No parent, even the most thoughtless, among the well-to-do classes would think of treating his son in this fashion. His whole scheme of education is founded on the principle of a slow and gradual loosening of the bonds of discipline. The close supervision of the private school is replaced by the larger liberty of the public school, which in turn opens into the greater but still restricted freedom of the University.

Freedom must come slowly. We want a bridge between the elementary school of the boy and the full-time workshop of the man. Such a bridge would be created 
by the establishment of the proposed half-time system. For half the day - or at any rate, for half his time-the lad between the ages of fifteen and eighteen would be compelled to attend a place of education, and only during the remaining half be permitted to undertake employment for wages. The advantages of this proposal are many. First, the influence of the school would be retained for an additional three years, and under the half-time system the freedom of the youthful wage-earner would find a suitable limitation in the half-time control of the school. Secondly, we should have the opportunity of another three years' medical inspection and medical treatment. With supervision over the health of the community continued until the age of eighteen we might fairly anticipate a rapid improvement in the physical efficiency of the worker. In particular, we should be able to detect, in a way now impossible, the effects of various forms of employment on those engaged in them. Inspection under the provisions of the Factory and Workshops Act, as has been shown, is too limited in character to do more than pick out a few young persons obviously unfit for the occupation they have selected; but, with the education authority responsible for the health of juveniles, and using to the full extent its powers to provide preventive measures or to veto in the case of certain individuals certain forms of work, we should have gone far to secure that no one should enter on or remain in a trade for which he was physically unfit. Thirdly, as already shown, a half-time system is the only really effective way of 
limiting the hours of juvenile employment. If the lad is compelled to be elsewhere than in the workshop for half his time, we have an automatic check on excessive work. Other advantages of this system will appear when we come to deal with questions of training and the provision of an opening.

The half-time system should be made compulsory throughout the country ; it ought not to be left to local option to decide. The local rating authority naturally wishes to encourage the establishment of workshops and factories within its area, and would be unwilling to adopt Acts which might prove a deterrent. It would be a most unsatisfactory state of affairs for employers to evade the spirit of the law by moving into districts where the law was not enforced. It is a little unfortunate that the Education (Scotland) Act, I908, which allows a limited amount of compulsion in connection with continuation schools, is founded on the principle of local option. The recommendations of the Consultative Committee of the Board of Education are vitiated in a similar way. Local option can never be really successful. It will elect to act only where there is least opposition from employers-in other words, where action is least necessary; and it will do nothing where boy labour is most exploited and regulation most urgently required. In one direction alone can local option be allowed with advantage. It may be permitted to decide on the precise kind or kinds of half-time to be enforced within their area. Boys might attend school on the half-day system or on the alternate day 
system. Or, again, they might spend three days in the workshop and three days in the school, or under certain circumstances devote six months of the year to the workshop and the remaining six months to the school. It would be desirable to allow the local authority considerable liberty in their methods of adapting the half-time system to the special needs of the trades of the district, provided always that a true half-time system was established.

There is no serious difficulty in the way of compelling attendance at the half-time school. It would be enforced just as attendance at the elementary school is enforced, and by the same officers. Further, no employer would be permitted to employ a boy between the ages of fifteen and eighteen who could not show satisfactory evidence of attendance at school. Or if, as may be the case, it is found desirable to permit boys to be engaged only by means of the Labour Exchange, the Labour Exchange itself would prove a most effective way of enforcing attendance.

There is nothing new or impracticable in the principle of the proposal. Compulsory attendance at continuation schools can be required in Scotland. Such attendance is compulsory in parts of Germany and Switzerland. ${ }^{1}$ It is exacted by certain employers in this country from their apprentices. Further, the fact that for many years the half-time system has been in use in the case of many

1 See Report of the Consultative Committee of the Board of Education on Continuation Schools, chap. $\mathbf{x}$. 
important industries, and tens of thousands of children so employed, demonstrates clearly enough that there is nothing impossible in the application of a half-time system to juveniles. It would, no doubt, cause some inconvenience, and some employers might dispense with the services of juveniles; but no more difficulty would arise than has arisen when any fresh regulations have been imposed; and we should see, as we have always done in the past, the employers who predicted inevitable ruin before the event, as soon as the proposal became law adapt themselves, with that placid content and admirable success which they have always displayed after the event, to the new condition of affairs.

\section{(d) The Parents' Point of View.}

The three proposals just made have one characteristic in common-they all directly set a limit to the employment of children and young persons. It is possible that some readers may regard them from another point of view, and say that in limiting employment they seriously diminish the income of the family. Will the poor parent, whose lot is pitiable enough as things are, be able to stand the loss ?

In considering this, the parents' point of view, we must guard against being caught in the noose of a vicious circle. We must not perpetuate an evil in order to mitigate its present effects. Many, probably most, of those parents whose income hovers about the margin of possible existence are in this pitiful position because their own child- 
hood has been neglected. As children, they have been overworked, and they are now physically unfit for regular employment; as children, they have been allowed to go uncontrolled and untrained, and now, as men, they are paying a heavy tax for the earnings of their boyhood. They receive little because they are worth little; their work is precarious because the sphere of their usefulness is small. We must not allow their children to live as they lived when children, and so pass on to the next generation the taint of inefficiency and its consequent wages of starvation merely because to-day wages of starvation need to be supplemented. We can never hope to overtake and pass an evil if we always cast it in front of us. The one clear message to the reformer of to-day is that he should look to prevention, and not merely to cure; and the one clear hope of a nation's future lies in insuring to every youth, as he crosses the threshold of manhood, the fullest realization of that development whose promise was his at birth. It might be well worth while for a country lavishly to endow poverty for a generation in order to free itself once for all from its fatal infection. But there is no reason to believe that we must resort to this drastic measure because there is no reason to believe that the proposed restrictions of child labour will in any way injure the parents.

Take first the earnings of school-children. There is very little reason to believe that they often make any effective contribution to the income of the home. They are irregular, they are small, and very frequently the boys 
retain them as pocket-money. Where they are large, as in the case of children employed during the pantomime season, they often form a convenient excuse for the parent to go idle for a time. The only large exception to this rule is the case of the widow. Here, indeed, the earnings do usually find their way home, materially increase the miserable pittance allowed by the guardians, and must be regarded as a tax levied on children in aid of the ratepayer. Humanity and a reformed Poor Law may be trusted to remove the tax.

Take next the raising of the school age to fifteen. The age has not been raised for more than ten years, and when it was last raised it was raised without friction and without complaint on the part of the parent. We might, perhaps, have expected that the percentage of attendance would have decreased because of the difficulty of enforcing it on the children of poverty-stricken parents. This has not been the experience ; indeed, the last decade has been remarkable for the rapid rise in that percentage. There is not a scrap of evidence to show that the last raising of the school age caused even temporary suffering on a large scale. Never was a large reform carried out with greater ease. There is no reason to believe that, if we raised the age again, that favourable experience would not be repeated.

We come now to the new half-time system. The earnings of boys between fifteen and eighteen years are considerable. To diminish them by one-half, it is urged, would be to adopt a course which would prove intolerable 
to the poor parent. Now, in the first place, though it is true that the lads could be employed for only half the time they were before, it by no means follows that they would only receive half the present money. We have already seen that the demand for boys far outruns the supply. The half-time system would halve the supply, and, though some employers might cease to use boys, the demand would certainly not be halved. The demand for boys would then considerably exceed the demand of today. The rate of wages would, in consequence, rise. The boys would no doubt earn less, but certainly more than half of what they now earn. In the next place, it must be remembered that the parent rarely receives the whole of the boy's earnings even during the first year, and each year the proportion of wages that comes to the home grows less. At the age of seventeen it is seldom that more than half finds its way into the family exchequer. The boy keeps the rest, and, as we have already seen, the large amount of money he has to spend on himself is by no means an unmixed benefit. The parent cannot usually get from the boy much more than is required to keep him ; indeed, he is afraid to enlarge his demand lest the boy, who is economically independent, should leave home. But under the half-time system, though he may earn his keep, he will rarely earn enough to support himself outside the family. In addition, the fact of being compelled to attend school will be a healthy reminder that he is not yet a man, and so check the growing spirit of independence. Home influence and parental authority will thus 
be strengthened, and the father will be able to exact a much larger share than before of the boy's earnings. Now, if the earnings are not diminished by so much as half, and if at the same time the parent obtain an increased proportion, it is by no means clear that the home affairs will suffer. Among the poorest families, where home discipline ceases altogether when the boy leaves school, it is quite possible that the financial position of the parent will be improved rather than worsened.

But we have not yet taken into account what is, perhaps, the most important consideration. The three proposals under discussion will undoubtedly largely diminish the amount of work performed by boys, but will not diminish the amount of work that requires to be done. Somebody must take up the tasks formerly allotted to boys, and, if boys fail, men must fill their place. Now, the work was given to boys because, to give it to men would cost more. In future, the work will be given to men, and more money will be paid for it than before. In other words, the increased earnings of men will more than make up for the diminished earnings of boys, and much more than compensate for the loss, because, as we have seen, only a portion of the boys' earnings ever reach the home. Or we may look at the question from another point of view, and say that the decreased use of boys will mean an increase in the demand for men, and, consequently, an increase in the wages of men. The Minority Report of the Poor Law Commission arrives at these three proposals by starting from the opposite point of view, and 
advocates their adoption not primarily for the good of the boys, but for the good of their parents. In the task of decasualizing labour, they are met with the difficulty that a considerable number of men will in the process be thrown out of employment altogether. Work must be found for them, and the easiest and the best way to find it is shown to be the withdrawal from the labour market of persons, like children, who ought not either to be employed at all or to be employed for such long hours as at present. Hence arises the suggestion of a rigid limitation of boy labour. It is much in favour of these proposals that they are the outcome of an elaborate analysis which in the one case begins with the man, and in the other with the child. We may take it, then, as clear that, from the parents' point of view, there is nothing to hinder us in raising the school age to fifteen, prohibiting the employment of school-children, and instituting a new half-time system.

\section{II. \\ TRAINING.}

The second essential in an apprenticeship system worthy the name is the provision of adequate training. The word "training" is used in its broadest sense to include preparation, not only for the life of the workman, but for the life of the citizen as well. In the preceding chapter we have seen that the scholarship schemes, connecting the elementary school with the University, and rapidly increasing throughout the country, are offering 
opportunities of training for those likely to rise high in the professional, the commercial, and the industrial world. It is probable that sufficient attention has not as yet been given to the supply of the most advanced kind of technological instruction, but the fault is being remedied, and the defect is due rather to lack of knowledge than to lack of will; and it is the instruction, and not the facilities of access to it, that is wanting.

What we are concerned with in this chapter is the training of those destined to fill the posts of foremen and managers of small undertakings, of the skilled workmen of the future, and of those never likely to rise above the ranks of unskilled labour. We are also concerned with those who will occupy corresponding positions in the commercial world. It has already been shown that the training of these persons is one-sided and inadequate, and. in the case of the majority, can hardly be said to exist at all. On the other hand, we have seen good reason to believe that the technical school can be, if not a complete substitute for the workshop, at any rate a necessary and fitting supplement. The day has gone by when it was necessary to argue at length the uses of technical instruction. Employers in this country, as they have long since done on the Continent and in America, recognize the advantages. Yearly, whether by compelling the lads in their service to attend the technical school, or forming themselves into committees to advise as to the most desirable methods of teaching, they are displaying a keener interest in the question, and a fuller faith in the 
possibilities of practical training given outside the walls of the workshop.

The defect of existing arrangements has been shown to lie in their limitation. For the majority technical instruction has been unsatisfactory or impossible of access. We must show in the present chapter how all may enjoy the advantages of training; but before doing so we must consider, a little more closely than has been done before, the kind of training required by the petty officers and the rank and file of the industrial army.

In much of the preceding discussion it has been assumed that what the man wants is an all-round training. This is undoubtedly a fact, but by an all-round training is not necessarily meant a training that will produce a craftsman of the old school, equally capable of turning his hand successfully to any of the operations with which his trade is concerned. Except in rural districts, in a few of the artistic crafts, and in certain branches of repairing work, a man of this kind is not generally required. It seems probable that the industrial tendencies of to-day are making decreasing demands for purely manual skill. The Report of the Poor Law Commission contains a valuable discussion of the question, and sums up the conclusions in the following passage: "The general trend of our answers was that the 'skill' of modern industry is scarcely comparable with the skill of labour in the past. One might say that, within twenty years, with the universal employment of machinery and the excessive subdivision and specialization of its use, the character of the 
productive process has quite changed. There is a growing demand for higher intelligence on the part of the few ; a large and probably growing demand for specialized machine-minders ; and, unhappily, a relegation of those who cannot adapt themselves to a quite inferior, if not worse paid, position. If, then, the 'skill' which we might have looked for and desired is what might be called ' craftsmanship,' we must conclude that the demand for skill is, on the whole, declining. The all-round ability which used honourably to mark out the mechanic is no longer in demand, so much as the work of the highly specialized machine-minder." 1 But if there seems a less demand for all-round skill, there appears to be an increasing demand for trained intelligence. "In the greater industries employing adult male labour, 'machinery' does not in the least resemble the long lines of revolving spindles one sees in a cotton mill. In the machine tools of an engineering shop there is comparatively little of such automatism, and, even where the machines are automatic, single men are put in charge of a number of machines, and the setting and supervising of these is work probably demanding a higher level of intelligence than ever before. 'I should say the skilled men require even more skill than they did,' says Mr. Barnes, ' because of the finer work and more intricate machinery.... Side by side with automatic machines there has come about more intricate and highly complicated machinery.' 'The semi-skilled of to-day,' says Sir Benjamin C. Brown,

1 Report of the Poor Law Commission, p. 346. 
' is in many cases as good as the skilled was a quarter of a century ago." "1 Or, as another witness puts it: "The tendency of machinery is always to cause a substitution of intelligence for dexterity, the person who was in effect a machine by reason of his dexterity giving place to one who could understand a direct and mechanical process." 2 There seems also good reason to believe that the demand for intelligence outruns the supply.

In the workmen, usually classed as skilled, the employer requires intelligence, but he wants something more; he wants trustworthiness, and frequently a certain highly specialized manual dexterity. The training of the workshop can supply the third of these qualifications; it cannot, however, supply the other two, which are in the main the products of education. But between the second and the third there is a certain antagonism. Monotony in the workshop does not cultivate intelligence; it is actively hostile to such growth. Unless there is a welltrained intelligence to begin with, the continual performance of a single task will reduce the man to the level of a mere machine. Now, the employer does not want a mere machine; if he did, in these days of inventive genius, he would soon discover something more reliable in the way of machines than flesh and blood. He wants a machine with intelligence; he must therefore have a man. But the intelligence must rest on a broad basis of education, or the machine element will prove too much for it. This

1 Report of the Poor Law Commission, pp. 346-347.

2 Ibid., Professor Chapman, footnote, p. 346. 
is the reason of the statement, found so often in evidence on technical training given by enlightened employers, that what is mostly required is a good general education.

Now we are coming to see that a general education does not imply a certain specific syllabus of instruction; it may be the result of the most varied kinds of instruction. We have ceased to take the narrow view that it consists only in book-learning and aptness with the pen. We have recognized that manual training may rightly play a large part in any system of education, and for the full development of certain types of mind is absolutely indispensable. Consequently, though the employer does not need the man of all-round skill, there is no reason why the workman should not acquire a general use of the tools employed in his trade. Whatever it may be to the employer, the possession of a certain amount of all-round skill is not a matter of indifference to the workman. If he can boast skill in a single operation alone, the bridge that lifts him above the gulf of unskilled labour is very fragile. A change in demand or a new invention may any day render his specialized skill useless, and precipitate him into that gulf whence is no escape. But this is not the case with the man who has received an all-round training. Thrust out of one branch of the trade, he can, if intelligent, comparatively easily find an opening in another. The all-round skill, though not required in the workshop, is necessary to the man if his position in the skilled labour market is to be secure. In a sense, the measure of his all-round skill is the measure of the stability of his 
industrial status. Further, the possession of all-round skill is a necessary condition of the possession of intelligence. It gives a man a clearer insight into the significance of his trade, and robs monotony of some part of its soul-killing power. Pure specialization is hostile to intelligence; the man who can only do one thing cannot do that one thing well. Finally, from these skilled workmen must be chosen the foremen and small managers, and these people must possess the wider knowledge and a more varied skill. To a large extent at the present time they are not recruited from the large workshop; they come from the country district, where this all-round skill can still be acquired. But, as we have seen, this supply is not inexhaustible, and there are signs that the methods of the industrial revolution are invading the village. Unless, therefore, we are prepared to see a scarcity of trained foremen in the future, we must to-day aim at producing the skilled workman, who is at once intelligent and possesses a general knowledge of the tools of his trade.

"We do not to-day," says Sir Christopher Furness, " want men who are all-round at building marine engines ; we do need men who are all-round mechanical engineersmen who can apply the principles of their craft to any form of machinery that may be called for. That is a class of training which cannot be achieved by any system of apprenticeship, and is essentially a matter which the governing authority must handle if this country is to maintain its position in the industrial world." 1 "The

1 Report of the Poor Law Commission, p. 35 I. 
characteristics," says the Consultative Committee, " that employers most value and most deplore the lack of would appear to be general handiness (which is really to a large extent a mental quality), adaptability and alertness, habits of observation-and the power to express the thing observed-accuracy, resourcefulness, the ability to grapple with new unfamiliar conditions, the habit of applying one's mind and one's knowledge to what one has to do." 1 It is clear that within the narrow sphere of the workshop an all-round training of this kind can never be secured.

We must look, then, to the elementary schools supplemented by the technical institute, to insure to the workmen an all-round intelligence and a general knowledge of the use of tools employed in his trade. For commerce, intelligence and an all-round training are no less necessary. "You produce a better clerk," it has been said, "if the boy takes an industrial rather than a commercial course." There is therefore no conflict of interest between what the employer wants and what the workman wants. The employer wants intelligence, and cannot get it from a workman who does not possess a general knowledge of his trade. The workman wants an all-round knowledge of his trade because without it his position as a skilled artisan is precarious and at the mercy of every new invention or change in fashion.

We have hitherto spoken as if all were skilled workmen,

${ }^{1}$ Report of the Consultative Committee of the Board of Education in Higher Elementary Schools, p. 7 . 
and as though the unskilled labourer did not exist. Now, there are at the present time huge armies of men that can by no stretch of imagination be regarded as skilled at anything ; but it is by no means clear that it is desirable for this huge army to continue as such. It is generally assumed that the performance of so-called unskilled work requires no training and makes no demand on skill. This is a grave mistake; let anyone, without previous experience, try a day's digging in his garden, and he will realize the fact. But it is not merely a question of manual training and practice; the unskilled labourer, to be efficient, needs intelligence. Skilled and unskilled work call for, in this age of machines, more intelligence than was wanted in the past. Almost everyone nowadays uses a machine of some sort; and there can be no question that in such use there is a serious lack of intelligence. The unskilled labour engaged with machinery is almost always inadequate and unsatisfactory. The agricultural labourer, for example, has to manage machines whose complex mechanism is far beyond his ill-trained intelligence to comprehend. The same may be said of the general run of machine-minders. Breakdowns, stoppages, and accidents are the costly consequences of their defect. Of all forms of labour, the unskilled labour of to-day is probably the most expensive to the employer. The labourer is worth, as a rule, little more than he receives, and, not infrequently, a good deal less. The preservation of stupidity is among the most foolish and most expensive of modern luxuries. What the employer wants 
is the intelligent unskilled labourer, and such a class must be the product, not of the workshop, but of the schools. The training to be provided would be very similar to that required by the skilled workman.

From the point of view of the employer, we require more intelligence in the unskilled labourer; from the point of view of the community and the man himself, the need is even more urgent. We must not forget the man in the labourer. He is not for all his time an unskilled labourer ; he is the autocrat of the home, the father of a family, and, as a voter, one of the rulers of the Empire. These last functions belong essentially to the highly skilled class of work. Uneducated parents are a danger to their children, and so to the future prosperity of the nation ; the illiterate voters a peril to the safety of the State. Finally, the man himself, with a wider outlook on the world, and with a life richer in interests, and so with more opportunities of healthy enjoyment, would be a happier and a better citizen. The shame of modern civilization and the abiding menace to its security lie in the miserable horde of stupid, unintelligent, and uninterested labourers who are good for nothing except the exercise of mere brute strength and indulgence in mere animal pleasures, and not very much good even for this.

Looking, then, at the problem of the training of skilled and unskilled workmen alike, whether from the point of view of man or master, we see that the great essential is the possession of a large measure of intelligence. With the continual changes in the methods of industry, men 
must be capable of changing too ; they must be capable of readily adapting themselves to new conditions, and not become petrified in a rigid and inflexible mould. Intelligence, properly developed, means adaptability. If we could secure this, the problem of dealing with the unemployed would be comparatively easy of solution. The inextricable tangle of to-day lies in the hopeless task of securing employment at a living wage for men who are not worth it. Let each man be made good for something, and it will not be beyond the range of wise statesmanship to find that good thing for him to do.

How is the necessary training to be provided ? The answer to this question need not detain us long. We have already seen that elementary and technical education can solve the problem in the case of those who have been able to avail themselves of the opportunities offered. The only outstanding difficulty was the difficulty of insuring ready access to all; and this has been surmounted in the proposals of the last section. The raising of the school age to fifteen, the prohibition of the employment of school-children, and the new half-time system, give facilities for education never before enjoyed.

The boy will remain at the elementary school till the age of fifteen, and there will be no employment outside school hours to undermine his health and render him unfit to profit by the instruction given. We have already noticed the transformation of the elementary school now going on, and the multiplication of various types of school. The process will continue, and the results fol- 
lowing the raising of the school age will be increased in value. The school will, in the first place, be regarded as a sorting-house, in which the different kinds of ability are discovered and classified. It will next be an institution where proper provision is made to insure that each kind of ability shall have the fullest opportunity of development. The only meaning of a general education is the discovery and the cultivation of the special interests of the individual.

When the boy leaves the elementary school his interests and ability will guide him to search for employment where they will have most scope. How this opening is to be found is a question that will be discussed in the next section. Let us take the boy who enters a skilled trade -say a branch of the woodwork industry-and follow his fortunes. He can be employed in the workshop for only half the day; during the remainder he must attend the half-time school. We have hitherto looked at this half-time school as a means of exercising supervision over conduct and physical development ; we must now regard it as a place of technical instruction. There must, therefore, be various types of schools corresponding to the different groups of trades. The boy who enters a woodwork trade will attend a school designed to meet the needs of that industry. At his place of employment he will no doubt be kept to a narrow range of operations, and in their performance will acquire that dexterity which only workshop experience can give. In the halftime school he will receive the training necessary to make 
of him an intelligent and all-round workman. Here his ordinary education will be continued; instruction in drawing, in mensuration, and in science-all specially adapted to the requirements of his trade-will be provided ; and, lastly, in the school workshop he will acquire skill in the general use of the woodwork tools. If it is urged that it will be difficult to find room in the curriculum for such varied training, it must be remembered that the subjects of instruction will all have formed part of the curriculum of the elementary school, with a bias in the direction of the woodwork industry. The boy will remain at the school for three years, and at the age of eighteen we shall have at least laid the foundation of those qualities required by the employer for success in the workshop and by the workman for success in life.

Let us take now the case of a boy who, on leaving school, finds employment in some occupation which does not lead to a skilled trade, and provides no educational training. Let us suppose he becomes an errand-boy. We cannot prevent lads of fifteen and upwards from being employed in such occupations, however undesirable, but we can at least guard against the more serious evils which are now the result. The boy will only be employed for half the day; he also must attend a half-time school. At this school he will continue his ordinary education; manual training will be provided to make him clever with his hands, while special attention will be devoted to his physical development. He will not, of course, be taught a definite trade, but will learn the general use of tools. 
How far, then, schools may be specialized into different types it must be left for the future to decide. We have hitherto never seriously considered the training of the unskilled labourer, and much pioneer work of an experimental character remains to be done. At the age of eighteen the lad, like his brother in the skilled trade, will be a valuable asset in the labour market. We shall have created what we have not got now, and what we much need-a race of intelligent and adaptable unskilled labourers.

There are certain other advantages which the half-time system can claim. First, the training of the workshop and the training of the school are carried on at the same time; instruction and practice go hand in hand. Secondly, only those boys will in general be taught a skilled trade in the schools who have already entered a skilled trade. This removes an objection often felt by Trade Unionists to what they term a multiplication through the schools of half-skilled workmen. Thirdly, we have in it a system of universal apprenticeship. All boys will have been learners, and worked for the same period at low wages. There will, therefore, be no obstacle of a privileged class to make difficulties in the way of those entering a trade who have not passed through the normal course of preparation for it. Fitness for the work will be, as it should be, the sole qualification.

Looked at in a general way, the half-time schools will be called on to play a double part. They must train the man in the interests of the community and in the interests 
of the trade. From the employer's standpoint these schools must be essentially places of practical instruction in close touch with the workshop. Already, under existing conditions, employers and representatives of the trade have been found willing to form advisory committees to visit the schools, criticize the teaching, and make suggestions for increasing its value. The principle must be extended; only in this way shall we get the expert inspection necessary to secure real efficiency. On the other hand, the education authority, the representative of the community, will manage the schools, and make them training-grounds of true citizenship. Under this double system of control, wisely administered, we shall not lose the man in the worker or the worker in the man; the interests of the individual and the interests of the employer will alike be safeguarded. In a real sense, and in fashion adapted to modern requirements, we shall have brought back the best traditions of the old apprenticeship system in which the gild, standing at once for the community and for the trade, watched over the training of the youth of the nation.

\section{III.}

\section{The Provision of an Opening.}

The third and last essential of an apprenticeship system is the provision of an opening. In the last chapter we have seen the aimless drift of boys as they leave school into "blind-alley" occupations; we have watched them 
rapidly slough off the effects of the school training; and we have found them a few years later left stranded without prospects ; and we have been driven to confess that this process of waste and demoralization is not a passing phase, but an integral part of the industrial development in its present unregulated condition. Boys, parents, employers are alike impotent to cure the evil; once again we are compelled to look to the State for help. The State must guide the choice of boys as they leave school. It must assist them during the period of adolescence to find better forms of employment, or at any rate to retain and increase the value of the school training, and it must bridge the gulf that now separates the work of the lad from the work of the man.

Already the necessary organization is in process of formation. We have seen how the establishment of Labour Exchanges for adults has, quite unexpectedly, led to the creation of special departments for juveniles. It is singularly fortunate that this accident has led naturally to the Board of Trade being regarded as the proper authority to carry out the work. It is, however, a fact that Parliament has recently passed an Act which gives power to education authorities to spend money for this purpose. It may do no harm for education authorities to be able, without fear of surcharge, to spend money in co-operating with the Board of Trade, but it would be disastrous if they came to think themselves the responsible authority for the undertaking. One of the chief objects of the machinery is the bridging of the gulf 
between youth and manhood. We should not enter on this difficult task with much hope of success if we perpetuated the distinction by making the Board of Trade responsible for the work of adults, and the education authorities responsible for the work of juveniles. Further, we are coming to see that questions of employment are questions which must be dealt with by a national, and not a local, body. Only a national authority, with its knowledge of the conditions over the whole country, could be in a position to estimate the prospects in any trade, or to decide as to the right proportions of boys to men. Next, the unit of area for employment bears no relation to the unit of area for educational purposes. Towns are separated from the adjoining districts. The unit of area for London employment, for example, is not the administrative county, but Greater London, and in Greater London there are more than thirty education authorities. If these are not in agreement-and when are thirty local authorities in agreement?-no system of regulation would be effective. If, let us say, the London County Council, in order to discourage the employment of van-boys, declined to supply them through their Exchange, their action would be without result if the adjoining districts did not follow suit, while it is impossible to conceive a more chaotic organization than one which would allow employers in the City to be canvassed for openings by thirty independent bodies.

For these and many other reasons the Board of Trade 
must be regarded as the dominant authority for the organization of the Juvenile Labour Exchange. On the other hand, there must be close co-operation between the Labour Exchange and the education authority. The Board of Trade has recognized the importance of this co-operation, and is making full provision for it in the machinery it is setting up. It is forming local advisory committees in connection with each Labour Exchange, and is making them practically responsible for the control of the juvenile department. On this committee are appointed persons nominated by the Board of Trade on the one hand, and on the other by the education authority. The committee thus represents the two branches of the organization. These committees are only just coming into existence, and it is too early to judge of their success. The problem is one of immediate practical importance; it is, therefore, desirable to consider a little in detail the principles that should guide them in their work. For the same reason it is desirable to ignore for the moment the proposals made in the preceding sections, to take things as they are, and to show what can be achieved under existing conditions.

The work of the Juvenile Labour Exchange divides itself naturally into a number of different parts or stages. The first stage is concerned with the boy while still at school. Some months before he is likely to leave he must be seen with the view of inducing him to make use of the Labour Exchange to obtain employment. A form will be filled up showing his position in the school, and 
any particular ability he may have displayed, recording the state of his health as revealed by medical inspection, and indicating any particular desire as to occupation expressed by himself or his parents. The interview and the filling up of the form will be undertaken by someone connected with the school organization-a teacher, or probably a volunteer. The institution of care committees for each school in connection with medical treatment, and the supply of meals to necessitous children, has enlisted the services of a large number of volunteers who would probably be found willing to make themselves responsible for this part of the work. The form, when filled up, will be sent to the Labour Exchange, where, if thought desirable, arrangements will be made by certain members of the advisory committee, in company with the secretary, to interview the boy and his parents.

The next part of the work is connected with the finding of vacancies. Either the employer will notify the Exchange of forthcoming vacancies or vacancies be obtained by canvassing employers. In either case it will be necessary to ascertain exactly the nature and the prospects of the employment. For this work expert knowledge is essential, and it will devolve almost entirely on the secretary or other paid officers of the Exchange. Having found boys wanting employers and employers wanting boys, it will be the duty of the advisory committee to bring the two parties together.

The second stage in the work begins as soon as the boy has obtained employment. It will be desirable, if pos- 
sible, to secure periodic reports, either by interview or by letter, from the employer, who in the majority of cases would no doubt be willing to give the information asked for. We should then know how the boy is getting on at his work from the employer's point of view. We must also know how he is getting on from his own point of view. For this and other reasons it is absolutely essential to keep in touch with the boy in his home. A tactful person, paying periodic visits to the home and seeing the boy, would soon learn what prospects the employment offered, what progress he was making, and would be able to advise him as to what evening classes he should attend, and to help him in those many ways in which a boy can be helped when first he goes out to work. In this way a large amount of valuable though unostentatious supervision would be kept over the boy. The persons most capable of doing this home-visiting are volunteers. In many cases the member of the school case committee who originally interviewed the boy would undertake the duty of supervision; in other cases we might get the assistance of the manager of a boys' club or other similar institution of which the boy was a member; but in all cases the advisory committee must make provision for supervision in the home. The reports from the home and the reports from the employer would be filed at the Exchange. They will enable the advisory committee to follow the career of every boy placed out, and at the same time gradually furnish a mass of detailed information respecting the employers of the district. 
To what kind of employers or to what classes of employment shall we send boys? To all who ask, or to only a selected number? Experience will no doubt show that there are certain employers of such a kind that under no circumstances ought we to trust them with boys. The number of such will be very small, and presents no serious difficulty. We should not supply boys until we had a guarantee that the conditions offered were improved. The question of the class of employment requires more careful consideration. There is a danger into which the advisory committee may easily fall. Recognizing the evils of " blind-alley " occupations, they may be inclined to refuse to send boys to such forms of employment, and only recommend boys to places where there is a prospect of learning a trade. Such a policy would be a fatal one. We should not thereby discourage "blind-alley" occupations, employers would get their boys as they have got them in the past, and the only result would be that we should lose all control over the boys, be unable to move them later to better situations, and so leave the problem not only unsolved, but, for want of knowledge, without possi. bility of solution. We ought not in the Labour Exchange to bar out any form of employment unless we are prepared to make that employment illegal by Act of Parliament. Street-selling might fairly come within that category, and no doubt other forms of employment will later be brought within the same class. But to bring them within that class, accurate information as to evil effects must be collected in order to stiffen public opinion, and if we wash 
our hands from the outset of all responsibility for such trades, we shall never have that accurate information. The first step in the way of regulation is that accurate knowledge which a detailed supervision of the boys placed out alone can give. There will, however, always be a temptation for the Exchange to confine its activities to the skilled trades, and let the others go. In Munich, for example, we find the education authority devoting much attention to the apprenticeship section of the work, while " unskilled labourers appear to be left to the Labour Exchange, and they receive, therefore, no advice in selecting their work." 1 The same tendency is seen in this country among the various voluntary associations for obtaining employment for boys. They have concentrated almost exclusively on the skilled trades. The results, expressed in figures or percentages, are pleasing, but altogether misleading. They ignore the large residuum which drifts without advice and without supervision into the less favourable openings, and in matters of social reform it is the large residuums that count. It is always nice to get a nice place for a nice boy that we know ; but if we do no more, there is no reason to believe that our action is of any advantage to the community at large. The nice places always are filled, and not infrequently the only effect of interference is that A., who is known, gets the job instead of the unknown $B$. The Labour Exchange must resist this temptation. It should

1 Report by Miss Durham to the London County Council on Juvenile Labour in Germany, p. 7 . 
aim at inducing all employers to obtain their supply of boy labour from the Exchange; its influence will then be at a maximum.

The mere establishment of a Juvenile Labour Exchange cannot create favourable openings; it cannot in itself alter the direction of the demand for labour. It might, therefore, be asked what is the use of an exchange for boys who can already find employment of a sort more easily than is good for them? First, there are the advantages of supervision and the opportunities for friendly advice and sympathy; secondly, there is the task of collecting accurate information which will lead up to legislative action, and the system of regulation which is ultimately inevitable; thirdly, while not closing the door to the "blind-alley" occupations, there is no need for the advisory committees to press them on the parent. They would, on the contrary, point out the evils, and suggest either that the opening should be refused or accepted only as a temporary expedient. The object should be to induce the parent to refuse situations which did not afford any prospects of learning or allow time off to attend a continuation school. The "blind-alley" occupations would disappear to-morrow if parents stubbornly refused to permit their boys to fill them. For the moment, moreover, the advantage is all on the side of the parent, as the demand for boys outruns the supply. But neither individual parent nor individual boy can take advantage of this fact; they have not the knowledge or the opportunity to make their voices effectively heard. There is 
no trade union of parents or trade union of boys, or, indeed, can be, in the "blind-alley" occupations. Collective bargaining must be done for them, and the advisory committee must be its instrument. They must first create the opinion among the parents, and then give effect to it through the Exchange. If employers found that, so long as they refused to offer better conditions, they were either unable to get boys or only got the least satisfactory boys, there would be a strong inducement for them to change their ways. Finally, there is the reverse of this system of educating the parents-the educating of the employers. There is already growing up a feeling among employers that if they cannot give the boys employment as men they might at least offer them opportunities of continuing their education. At a conference held in rgro between agencies interested in the welfare of boys and employers of labour, under the presidency of the Chairman of the London Chamber of Commerce, the following resolutions were unanimously adopted : "That the London Chamber of Commerce be asked to consider the advisability of establishing a register of its members who would be willing to engage or apprentice boys with a view to the co-operation of the Chamber with the various institutions interested in the welfare of boys." " That employers of labour be recommended, by reducing the present hours of labour or otherwise, to give such facilities as may be possible consistently with the requirements of their business to enable boys and youths to obtain technical instruction." Judicious canvassing among a certain class of employers 
may, therefore, lead to most beneficent results. It should also be borne in mind that in London and other towns into which there is a large immigration of adult labour', there is room for new openings leading on to skilled trades.

While much can unquestionably be done under existing conditions to improve and supervise the conditions of boy labour by means of the Juvenile Labour Exchange, it is certain that sooner or later there will be need of regulation by Act of Parliament. Probably the best course would be to give the Board of Trade power in the case of certain occupations to limit at their discretion the employment of boys to boys engaged at the Exchange. If in addition the proposals made in the previous sections were to become law, we should be in a very strong position to launch the youth on the ocean of manhood with all the prospects of a successful voyage.

\section{IV.}

\section{General Conclusions.}

At the end of a long and rather complex discussion it is desirable to attempt some general summary of what has already been achieved and of the proposals necessary for the creation of a true apprenticeship system. It will make for clearness if we take a boy and follow his career through its various stages.

At the age of five or thereabouts he will enter the elementary school. It is to be hoped that the reorganiza- 
tion of the public health services and the more careful attention devoted to the period of infancy may send him to the school free from those physical defects so common now, and healthy within the limits of nature. Here he will begin his education. Improved methods of teaching will make for increased intelligence and the growth of numerous interests, while physical exercises, medical inspection and treatment, added to the supply of wholesome food to the necessitous, will promote the healthy development of his body.

At the age of eleven comes an important epoch in his career. It is then that, if found suitable, he will, with the help of a scholarship, be sent to the secondary school, and thence be led along a broad road to the University. Failing the winning of a scholarship, he will, if he display any special aptitude, be drafted off to a central school with a commercial or industrial bias. Failing, again, the proof of any exceptional ability, he will remain in the ordinary school. In either case he will continue at school till the age of fifteen, will be forbidden to work for wages outside school hours, and will throughout be periodically examined by the school doctor.

With the approach to the age of fifteen begins the second important epoch in his career. Some time before the day of leaving school arrives he will have been interviewed by a friendly volunteer, who, with the help of the school record and medical register, will be able to decide for what form of employment he is best suited. In the meanwhile the Labour Exchange will have found for him 
a suitable opening, or, failing this, a temporary situation pending a more satisfactory and permanent position. If he gain a place in a skilled trade, the half-time school, which he must attend for the next three years, will add to the training of the workshop that all-round training, whose result is intelligence and adaptability, required to make of him an efficient artisan. If he is destined to fill the ranks of unskilled labour, he will likewise attend a half-time school carefully designed to enable him to play a useful part in the world of life. In both cases he will remain for half-time under the supervision of the education authority ; in both cases periodic medical inspection will watch over his physical development, and if it show him physically unfit for the work he has undertaken, he will be found employment more suitable to his strength; in both cases the advisory committee of the Labour Exchange will receive reports from the home, the school, and the employer, and these reports will enable them to discover whether the occupation and the training are well adapted to foster his natural abilities. For three years, while at work, he will also remain at school; for three years his training will be guided by employers who will see to it that it turns out the efficient workman, and by the education authority, which, acting in the interests of the community, will see that it makes for the efficient citizen.

In process of time, with the gradual accumulation of experience, and with the knowledge of the Board of Trade behind it, the advisory committee will be able to adjust 
the supply of boys in course of special training to meet the demands of special trades, and even if some unforeseen transformation of industry upsets the calculations, there should be no insurmountable difficulty of disposing of lads at the age of eighteen who are at once well conducted, physically fit, and intelligent.

We come back to the position from which we started in the introduction-the need of securing for the youth of the country adequate supervision up to the age of at least eighteen, appropriate training during that period, and at its conclusion the provision of an opening in some occupation for which special preparation has been given. We have seen that for at any rate a large section of the people these conditions were satisfied during the best days of the gilds, and that they were satisfied in direct proportion to the extent to which the gilds stood for the common interests. With the decay and disappearance of the gilds the training of the youth became a matter of individual bargaining between parent and employer. No authority, standing for the common good, superintended the process. Apprenticeship might be enforced; its efficiency could not be guaranteed. Further, the existence of apprenticeship tended to create a privileged class who resented the intrusion of those who entered a trade by other means. With the coming of the industrial revolution, training itself became more difficult. The large workshop and the division of labour were unfavourable to apprenticeship. Employers wanted to use boys, and not to train them. Rapid progress of invention con- 
tinually discounted the value of acquired manual skill, and parents could not see at the conclusion of the apprenticeship any prospect of a favourable opening in a skilled trade; while the gradual break-up of the system of supervision bred a spirit of independence among boys which rendered them disinclined to bind themselves for a period of years. Finally, competition, with the urgent need of surviving the struggle of to-day, made it hard for employers to prepare for the future by providing for the training of the future workmen. The industrial system gave no guarantee for the efficiency of the next generation of workers. The old apprenticeship system had broken down.

But in the period of general disintegration there was slowly developing-at first unconsciously, and later with more clearly directed effort-an organization which made for constructive reform. It was called into being as a last resort, and to save the country from the ruin which was threatened by the exploitation of children. Competition demanded the sacrifice of to-morrow to-day; the State, whose interests belong to all time, was driven to forbid the sacrifice. Competition demanded that children of tender years should labour in the mines and the factories, and under conditions that made all health a mockery; the State insisted on a minimum standard of health and safety for its children. The standard, low at first, has steadily been raised. Thus has grown up the regulation of child labour and the Acts relating to factories and workshops. Competition cared nothing for the 
education of the children; it wanted to use them up and cast them on the waste-heap. The State, recognizing the dangers of an uneducated people, established by slow degrees a system of universal education. So the struggle between the two has gone on, the State only interfering as a last resort and in despair of other means to stop the evil. Throughout its action has been generally beneficial, but the benefits have been limited because that action has been partial and patchy. Much of the expenditure, for example, on education has been wasted just because the education came to an end too soon. The time had come for a more comprehensive study of the situation that should indicate the faults of the existing system.

Such a study has been attempted in the present volume. The task has been comparatively easy, because the evils are generally admitted. What has not hitherto been recognized sufficiently is the fact that these evils are growing, and not in course of removal. The various factors in the process have been examined, and, ignoring the State, they are clearly inadequate, and progressively inadequate, to the task of solving the problem. As a last resort the State remains. If the principles underlying the training of youth are admitted, if out of the various possible forces concerned all with one exception have been proved defective, then we must put our hopes in the one exception. We must enlarge the sphere of influence of the State. How this should be done has been shown in the present chapter.

The principles underlying the proposals have all been 
drawn from experience, and are founded on the apprenticeship system, but applied with modifications suitable to changed conditions. Under the gild system there were three interests concerned and conjoined-the interests of the master, the interest of journeyman and apprentice, and the interest of the community. Since the gilds have gone these interests have become separate and increasingly antagonistic. For the successful training of the youth of the country the claims of these clashing interests must again be brought together and reconciled. Ultimately and in the long-run they are identical; it is only competition, with its dimmed and narrow vision, that made the cleavage. It is hoped that the proposals outlined in this chapter will point the road towards a final peace. Let us, in conclusion, bring them to the test of the three essentials for which a true apprenticeship system must make adequate provision.

There must be supervision-supervision of conduct, supervision of health. Under the new apprenticeship system the State will be the ultimate authority for the supervision of conduct. Till the age of fifteen the boy will remain subject to the control of the schools. Long experience has demonstrated the beneficent influence exercised by the teachers over the children even under present conditions, when the school career is brought to an end at the age of thirteen or fourteen. There is, therefore, nothing wild in the expectation that, with com. pulsory attendance extended to the age of fifteen, we shall receive richer and more lasting fruits. For the 
next three years, the critical period of a boy's life, with its first experience of the workshop and the sense of independence which comes with earning wages, the supervision of the State will only in part be withdrawn. During these years he will be compelled to attend the half-time school, and so continue under the control of the education authority. Nor is this all. The advisory committee of the Labour Exchange will advise him in the choice of employment, assist him to obtain it, and generally watch over his career. Thus, helped on his journey and surrounded with wise and friendly influences, he will approach the threshold of manhood with such promise of success as good habits and an ordered life may bring.

The State, likewise, will be responsible for the supervision of the boy's health. Periodic medical inspection will watch and aid his physical development. We have not yet learned to appreciate the full value of this periodic inspection; it is, however, destined to become the most powerful instrument of reform. The ill-nourished child, the delicate child, the child in the early stages of phthisis, the child of negligent parents, the child from the overcrowded or insanitary home-all these, the future weaklings of the nation, we know them now only when the evil has too often outrun the possibility of a cure and it is too late. Under the new conditions we shall detect the evil in its first beginning, while there is yet hope. Medical inspection is also the key to the situation after the boy goes out to work, and for three years he will remain under its control. At the present time we only 
dimly realize the disastrous effects that come to a boy from the choice of an occupation ill-suited to his strength. We forbid a few forms of work, attempt for the most part ineffectively to limit the hours of employment in a few others, but in our clumsy fashion legislate as a rule for the normal child, and it is the abnormal child that suffers most. Under the new conditions there will be no work for children under the age of fifteen, while for the three following years medical inspection will enable us to legislate for the individual boy, taking into account his physical characteristics. Not only shall we be able to help a boy to avoid making a wrong choice, but we shall be able to remove him as soon as medical inspection shows him unfit for the work. Thus, to the age of eighteen the State has its finger on the pulse of the youth.

Secondly, there must be an adequate provision of training, special and general, accessible to all. Here, again, we are building on the firm rock of solid experience. The elementary schools have proved themselves to be schools for the cultivation of intelligence. With a year or two added to the school life; with the relief from that distracting influence which comes from wage-earning while at school ; with the improved methods of teaching and a clearer differentiation of types of school to suit varying types of mind-reforms already under way-we may fairly hope for a general rise in the intelligence of the boys. The half-time school, with its three years' course, will supply the more specialized training required in the different trades and occupations, while committees of 
employers will provide the expert criticism essential to success.

Finally, there must be the provision of an opening in some form of employment for which special preparation has been given. The Labour Exchange, the juvenile branch worked in close co-operation with the adult section, will supply the opening, while the technical training will give good guarantee for the adequacy of the preparation. The Elementary School, the Half-time School, the Education Authority, and the Advisory Committee, all acting together, will insure a safe passage from youth to manhood.

The new apprenticeship system is more complex than the old-it lacks something of the picturesqueness of the Middle Ages-but it finds its compensation in an organization at once more flexible and more comprehensive, and therefore better suited to stand the shock of those huge changes in methods of production and methods of living which have been the ungainly offspring of the industrial revolution. 


\section{LIST OF AUTHORITIES}

I

PARLIAMENTARY AND MUNICIPAL PUBLICATIONS

Elementary Schools (Children Working for Wages), Parts I. and

II., Parliamentary Return. I 899.

Report of the Interdepartmental Committee on the Employment

of School-Children. I90I.

Report of the Departmental Committee on the Employment of

Children Act, 1903. r910.

Report of the Royal Commission on the Poor Laws and the Relief

of Distress. I909.

Report by Mr. Cyril Jackson on Boy Labour. I909.

Report of the Commissioners of Prisons for the year ending

March 3I, 1908.

Report of the Chief Medical Officer of the Board of Education for the year 1909.

Report of the Consultative Committee of the Board of Education on Higher Elementary Schools. 1906.

Report of the Consultative Committee of the Board of Education

on Attendance, Compulsory or Otherwise, at Continuation

Schools. 2 vols., 1909.

Report on the By-Laws made by the London County Council under the Employment of Children Act, 1903, by Chester Jones. 1906.

London County Council Report of the Medical Officer (Education) for the year 1906 .

London County Council Report of the Medical Officer (Education) for the year I909. 
London County Council : Medical Treatment of Children attending Elementary Schools-Report of Education Committee. I909. London County Council : Home Circumstances of Necessitous

Children in Twelve Selected Schools. Igog.

London County Council : The Apprenticeship Question. 1906. London County Council : Report of the Higher Education SubCommittee on Apprenticeship : Agenda of Education Committee, February 24, 1909, pp. 412-425.

London County Council : Technical Education Board Report on the Building Trades. 1899 .

London County Council : Report by Miss Durham, Inspector of Women's Technical Classes on Juvenile Labour in Germany. r9ro.

London County Council : Report by Mr. R. Blair (Education Officer) on Organization of Education in London. P. S. King and Son, Westminster.

County Council of Middlesex : Report by Mr. A. J. Bird (Inspector of Schools) on Employment Bureaux for Children of Schoolleaving Age.

Urban District Council of Finchley: Annual Report of the Medical Officer of Health, including the Report to the Education Committee for the year 1908 .

Gloucestershire Education Committee: Report of the Minor Committee to consider Certain Proposals for the Creation of an Apprenticeship Fund and a Labour Bureau. 1907.

\section{II}

\section{AUTHORS}

Abraham and Davies: Factories and Workshops. 1902. ABRAM, A. : Social Life in the Fifteenth Century. I909. Alden, Margaret : Child Life and Labour.

Ashley, W. J.: Introduction to English Economic History. I 888.

BEVERIDGE, W. H. : Unemployment. I909. Black, Clementina : Sweated Industry. 1907. BlaIR, R.: Some Features of American Education. 1904. Booth, Charles : Life and Labour of the People, 9 vols. 1896. BRAy, Reginald A.: The Apprenticeship Question, in Economic Journal, September, I909. 
Bray, Reginald A.: The Town Child. r907.

Christian Social Union : Report on the Employment of Boys in the London Area. I9ro.

Continuation Schools in England and Elsewhere, edited by M. E. SADLER. 1907 .

CReasey, Clarence H.: Technical Education in Evening Schools. 1905.

Crowley, Ralph H. : Hygiene of School Life. 1909.

Cuningham, W.: Growth of English Industry and Commerce: Early and Middle Ages. 1905.

. $\quad$ Growth of English Industry and Commerce: Modern Times, 2 vols. 1903.

Davies, Maude F.: Life in an English Village. $x 909$.

Frere, Margaret : Children's Care Committees. 1909.

Gibb, The Rev. Spencer J. : The Problem of Boy Work. 1906. Boy Work and Unemployment. C.S.U. Pamphlet.

Gordon, OGILvie : Handbook of Employments. 1908.

Green, J. R. : History of the English Peoples, vols. i. and iv. 1896.

Green, Mrs. J. R. : Town Life in the Fifteenth Century, 2 vols. I 894 .

Hall, G. Stanley : Adolescence, 2 vols.

HASBACH, W. : History of the English Agricultural Labourer. 1908.

Hawkins, C. B. : Norwich: A Social Study. rgro.

Hayward, F. H.: Day and Evening Schools. rgro.

Hogarth, A. H. : Medical Inspection of Schools. 1909.

HutchINS AND HARRISON: A History of Factory Legislation.

1907.

JaCkson, Cyril: Unemployment and Trade Unions. I9IO.

Jebb, Eglantyne: Cambridge: A Brief Study in Social Questions. 1906.

KeELING, Frederic: The Labour Exchange in Relation to Boy and Girl Labour. I9ro.

Krrkman, Gray B. : A History of English Philanthropy. 1905. Philanthropy and the State.

KNowles, G. W. : Junior Labour Exchanges. I9ro. Macmillan, Margaret: Labour and Childhood. I907. Moseley: Educational Committee Report. I904. 


\section{BOY LABOUR AND APPRENTICESHIP}

Nicholls, Sir G. : History of the English Poor Law. 1898. ROGERS, J. E. T. : Six Centuries of Work and Wages. 1884 . Rowntree, B. S. : Poverty : A Study of Town Life. I90r. Russell, C. E. B. : Manchester Boys. 1905.

RUSSEll AND RIGBY: The Making of the Criminal. 1906. Working Lads' Clubs. 1908.

SHADWELl, ARTHUR : Industrial Efficiency. 1909. Studies of Boy Life in our Cities, edited by E. J. URwICK. 1904. TAwnEY, R. H.: The Economics of Boy Labour, in Economic

Journal, December, rgog.

Trades for London : Boys. Compiled by the Apprenticeship and Skilled Employment Committee. 1908.

Trades for London: Girls. Compiled by the Apprenticeship and Skilled Employment Committee. I909.

TuckWell and Smith : The Workers' Handbook. 1908.

Webb, Sidney and Beatrice: History of Trade Unionism. 1907 .

Industrial Democracy, 2 vols. I897.

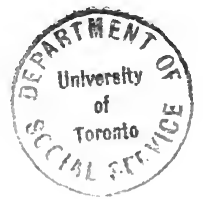




\section{N DEX}

Abraham and Dafies, 45, 49, 53

Abram, A., 9

Adler, Miss, 106

Adolescence, vi, I76, I98

Agricultural Gangs Act, 42

Apprentices, statute of, I3-I5 ; effect, I6, I7; pauper, I5, I7-I9; repeal, 22

Apprenticeship, break-up of, I65-I 75

charities, I9; decay, 25, I35, I64, I65-I75, I77 ; difficulties of, I2, I88; essentials, 43, 237 ; indentured, $5,135,187-$ I89; meaning, $I$; under gilds, 4-II, 234, 237 ; under industrial revolution, 26-29; under statute, IIII9; universal, $3,13,189$

of to-day : contribution of home, 92-I03 ; of philanthropy, 89-92; of State, $73-74,76-89$; of workshop, ro3-I65

the new: Juvenile Labour Exchange, 23I-23I ; new half-time, I9I, I97202 ; prohibition of employment, I9I, I95-I97 ; raising school age, I9II95, 2 I 7 ; summary, 23I240

Ashby, W. J., 4
Attendance at school, Acts relating to, $38,46-48$; percentage of, 83 , I06, I05

Blair, R., 86

"Blind-alley" occupations, 87 , I I 2, I $23-I_{30}, I_{45}, I_{57}, I_{58}$, I63, I69-I72, I 80, 227

Board of Education, 6I, 64

Board of Trade, 7I, 72, 223,233

Booth, C., 95, I04, I 36, I 39

Borstal Association, I69

Boy labour: difficulties of regulation, 79,80 ; effects of regulation, 77$82,88,89$

half-time, $49-52,78$, 197$202,204,205$

health and safety, 52-58, $77,197-202$

limitation of hours, 43-52, 197-202

prohibition of, 4I-43, I95I97, 203, 204

regulation under gilds, 7II, 234, 237; under industrial revolution, 2025 ; under statute, I3, 14

Boys : clubs, 90 ; errand, 82, II2, II9, I29, I 45 ; lather, 43 ; office, II9, I26, I 58 ; shop, I22, I26, I 28, I 45 ; telegraph, I26, I3I, I45; van, 82, I I9,

I 45 
Boys: employment of, at school, IO3-II3, I5I-I55; on leaving school, I I4-I I9, I63 ; entering manhood, I 43

unemployed, I I9; under London County Council, I 32

Bursaries, 65

Chamber of Commerce, 230

Chapman, Professor, 2 I I

Child, definition of, 40

Children Act, 38, 59, 6r, 80

Children, employment of. See Boys

Chimney Sweepers Act, 42

Cloete, J. G., 126, I29

Coal Mines Regulation Act, 38, 42

Competition, I77, 235

Cuningham, W., 4, 6, 10, I6, $20,22,28$

Davies, Miss Maude, I6I, I64

Distribution of trades, I I 5-I I 8, I 42-I 49, I63; normal, I 47-I 49 Durham, Miss, r96, 228

Economic Journal, I I6, I 59 Education Acts, I902-03, 62

Administrative Provisions Act, 1907, 58, 60, 6r

Provision of Meals Act, $6 r$ Employment of children. See Boys

Employment of Children Act, $38,40,41,42,43,46,48,57$, $58,77,80,8 \mathrm{I}$, I I I, I66

Factory legislation, causes of, 30

Factory and Workshops Act, 38 , 168; authority for enforcement, 4O, $5 \mathrm{I}$; definitions, 39-4I ; effects of, 77 , $8 \mathrm{I}, 82,88$; half-time, 49-5I; health and safety, 52-56; limitation of hours, 43-52; prohibition of employment, $4 \mathrm{I}, 42$

Furness, Sir Christopher, 213

Gibb, Spencer J., I24, ${ }_{5} 8$

Gilds, 4-II, 234, 237

Girls, vii

Green, Mrs. J. R., I2

Half-time system, 49-51, 78, 197-203, 204-205

Hall, G. Stanley, vi

Hasbach, W., 25

Health and Morals of Apprentices Act, 17, 18, 23, 29

Hutchins and Harrison, 23, 29

Idealist, triumph of, 28

Indenture, old, 6

Individualist, triumph of, 32-34

Industrial revolution, $20-26$; effects of, 26-29, I73I 75 ; characteristics, I77185

schools, 6I

Jackson, Cyril. See Report on Boy Labour

Labour Exchange, 70, 125 ; Juvenile, 7I, 72, 83, 20I, 22I-23I, 232-24O

Lather-boy. See Boys

London, employment of schoolchildren, $\mathrm{IO}_{5}-\mathrm{II}_{3}$; entry to a trade, II3-I42; passage to manhood, I 42-I 5 I

Medical certificate, $56,57,5^{8}$ inspection, $58,60,6 \mathrm{I}, 85$, $86,94,168,197,23 \mathrm{I}$, $232,233,238,239$

Messenger-boy. See Boys

Metalliferous Mines Regulation Act, 38

Mines (Prohibition of Child Labour Underground) Act, $38,4^{\mathrm{I}}$ 
Necessitous children, 94, 95

Nicholls, Sir G., 18

Occupations, clerical, I40-I42; distribution of, II 5-I 2O, I 43 , I42-I 49, I 63 ; skilled, I $32-$ I 40 ; unskilled, I I 2, I 2 I-I 33 Office-boy. See Boys

Opening. See Provision of

Poor Law, Elizabethan, I 5 ; Amendment Act, 23-26 ; Report of Royal Commission. See Reports

Prevention of Cruelty to Children Act, 38, 42

Provision of opening, need for, 2 ; Labour Exchange, 7072 , 22I-23I, 240; under gilds, 8-II ; under industrial revolution, 20-26

Report of Board of Education, of $^{64}$ Commissioners for Prisons, I69

of Consultative Committee on Continuation School, 47, 8I, I54, I92, 201

of Consultative Committee on Higher Elementary Schools, 2 I 4

of Departmental Committee on Employment of Children Act, 8I, I 25

of Interdepartmental Committee on Employment of Children, 5I, IIO, I 52

of London County Council on Apprenticeship, 66, I I $5, I_{2} 8, I_{35}, I_{36}, I_{39}$, I $40,143,187$, I92, I 94 of Medical Officer, Board of Education, I 52, I 74

of Medical Officer (Education) of London County Council, 96, I09, I ro
Reportof PoorLaw Commission,

31, I04, I 55, I 56, I72, 19I, 192, 206, 209, 210 , 2II, 2 I3

Report on Boy Labour, by Mr. Cyril Jackson, $\mathrm{IO}_{4}, \mathrm{I}_{23}$, I24, I25, I 28, I 29, I 3 I, $144,145,1_{4} 6,1_{5} 6, I_{57}$

on Home Circumstances of Necessitous Children, 95 Rogers, J. E. Thorold, 5 Rural Districts, I6I-I65

Sadler, M. E., I 57, I 7 I, I 95 Scholarships, $66-68,86,232$ School : age, 46-48, I92-I95 ; central, 64, 65 ; elementary, $46,47,63-65,83-86,2$ I 8 , 224, 231 ; evening, 60, 67,69, 86 ; industrial, 59,61 ; parttime, 68, 132, 187, 2 18-221, 231 ; secondary, $60,67,86$, 232 ; Sunday, 89 ; technical and trade, 60, 66, 68, 208

Scott-Holland, Canon, 124

Shop-boy. See Boys

Shop Hours Act, 38, 46, 79, 8I Skilled Employment Committees, $91,92,185$

Supervision, need for, 2 ; under gilds, 8-II ; under statute, 13-I5; under industrial revolution, 20-26; by State regulation, 37-58; by State enterprise, 59-70 ; effects of State, 76-88; by philanthropy, 89-92 ; in home, 92I03; in workshop, 125 ; in London, summary, I49, I50 ; general summary, I65-I68; under new apprenticeship, I9I-202, 22I-23I, 237, 238

Tawney, R. L., I 59, I60 Technical instruction. Schools

Trades, distribution of, II 5I 20, I 42-I 49, I63; picking up, I36-I 40 ; skilled, I 33-I 42. 
208-2I4, 218,239 ; unskilled, I I 2, I 2 I-I 33 , I 55-I60, I65I 75, 208, 2 I 5. 2I6, 2I9, 239

Training, need for, 2 ; under gilds, 9-12 ; under statute, 13, I4; under industrial revolution, 20-27; in single operation, 21, 137-139; in elementary schools, 63-65 ; in continuation schools, 65- Young person, 40, 44-46, 8I,
70 ; in workshops, III-II I2I-I 42, I65-I75,; in ne apprenticeships, 207-22I, 2 .

Van-boy. See Boy

Webb, Sidney and Beatrice, 2I, 22

THE END 




\section{PLEASE DO NOT REMOVE CARDS OR SLIPS FROM THIS POCKET}

\section{UNIVERSITY OF TORONTO LIBRARY}




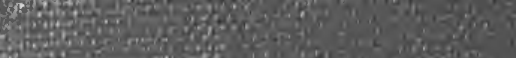

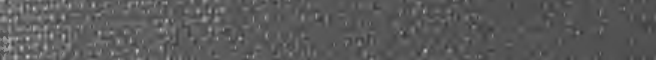

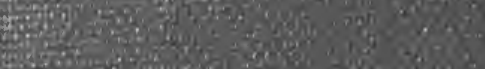

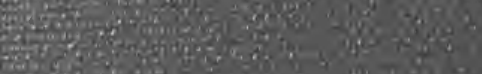

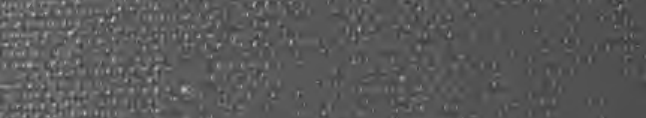

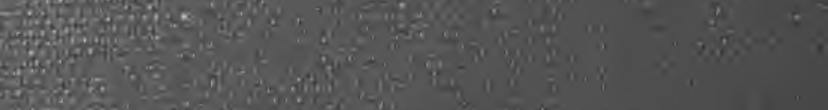

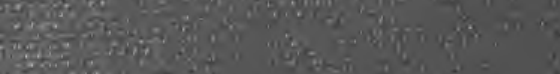

9.

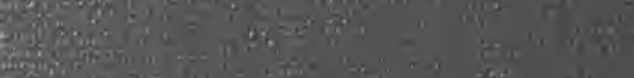

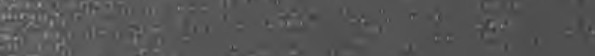

(6)

?.

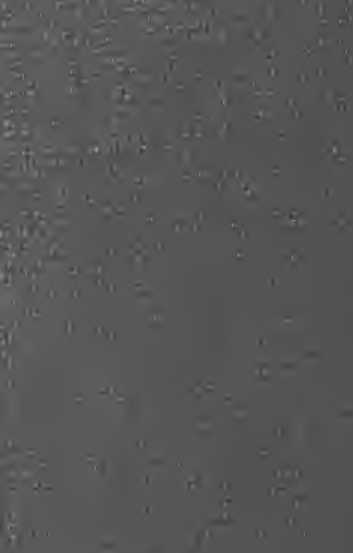

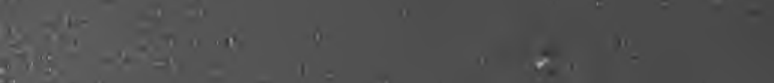
$65=7,7$

is

4.

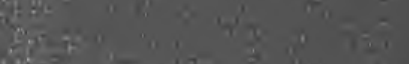

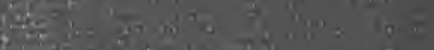

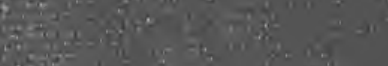

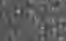

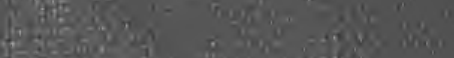

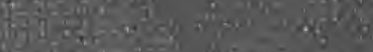

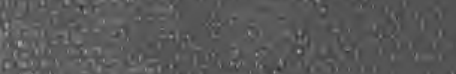

20. Sis a

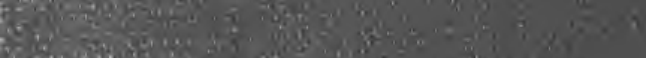

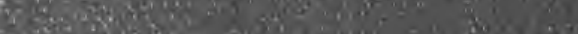

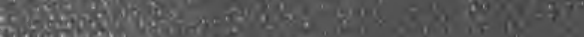

